\title{
A ROAD LESS TRAVELLED \\ THE AMERICAN BIKER FILM OF THE 1960s AND 1970s
}

By

William Liell Carter

A thesis submitted to the Victoria University of Wellington

in fulfilment of the requirements for the degree of

Master of Arts

Victoria University of Wellington

December 2010 
TABLE OF CONTENTS

$\begin{array}{lr}\text { ABSTRACT } & 5\end{array}$

ACKNOWLEDGEMENTS

CHAPTER ONE: INTRODUCTION 9

CHAPTER TWO: SOME HISTORICAL CONTEXTS 27

CHAPTER THREE: NARRATIVE

CHAPTER FOUR: GENDER AND GENRE 81

CHAPTER FIVE: CONCLUSION 109

$\begin{array}{ll}\text { APPENDIX } & 115\end{array}$

BIBLIOGRAPHY AND FILMOGRAPHY 


\section{THESIS ABSTRACT}

In the period 1966-1974 there were at least forty independent, low-budget feature films made in the United States about motorcycle gangs. These films were inspired by media coverage of the notorious exploits of actual gangs in the post-War period. They depict bikers as violent libertines who live nonconformist lives and engage frequently in anti-social behaviour. The films are marked by motorcycle 'runs,' wild parties, brawls, and sexual violence. While the biker film has received some critical attention, it has not been analysed to the same extent as that more reputable and better known genre of the same period, the road movie. This thesis will expand on existing research by initially examining the factors that shaped the biker film, such as the media panic about real gangs, the influence of the counterculture, exploitation filmmaking, and New Hollywood cinema. The project will also investigate the narrative features of the genre, and link this analysis to debates around post-classical narration. Finally, the thesis will interpret the representation of gender in the biker film. This thesis will argue that the biker film should be situated within a continuum of male-oriented genres that involve violent spectacle. It will also make a contribution to the ongoing research on New Hollywood cinema. 


\section{ACKNOWLEDGEMENTS}

I would like to thank my supervisor, Tim Groves, for his enthusiasm, guidance, and encouragement. I would also like to express my gratitude to the academic staff of the School of English, Film, Theatre and Media Studies (SEFTMS) who have given me assistance with this project, including Russell Campbell, Sean Redmond, Lee-Jane Bennion-Nixon, and Geoff Stahl. My fellow postgraduate students Brady Hammond, Mark Ellsworth, Allison Maplesden, Akil Kirlew, Kerry Glamsch, and Adnan Khan were sources of good humour and support.

This thesis would simply not have been possible without the help of my parents, Edward and Ellie, who have shown me constant love, patience and encouragement throughout this project. I would also like to thank my friends, in particular Wolfie, Lennart, Todd, Philobst, Yung-bal, Pål, AJ, Luke, Nico and Hari. Finally, I owe a huge debt of gratitude to my partner, Anna. Her faith in, and support for, both this project and myself have been incredible. I thank her wholeheartedly. 


\section{Introduction}

In the period between 1966 and 1974 at least forty biker films were made in the United States. ${ }^{1}$ Although 1974 was the year in which the biker film largely disappeared, it began declining after 1971. ${ }^{2}$ Many of these films had exotic titles, such as The Wild Angels (1966), Savages from Hell (1968), Hell's Chosen Few (1968), Satan's Sadists (1969) and Angels Die Hard (1970). Because the titles of many biker films in this period feature words such as 'hell,' 'devil,' 'savage,' 'rebel,' and 'wild,' this suggests that these films deal with themes of danger, violence and non-conformity. As Ina Rae Hark argues, “'Wild' is the privileged adjective Hollywood employs to describe the liberatory yet dangerous road ethos." 3 These biker film titles enticed audiences who enjoyed stories with lurid elements, and they were not disappointed. These films contained plenty of violence, sexual transgression and anti-social behaviour. These films are also much less well known than those of the road movie genre. This is interesting because, despite having similar narrative conventions and being produced in roughly the same period, the road movie has received more critical attention.

\section{Key Arguments}

This thesis will argue that the biker film is significant because of its narrative structures and the interrelationship it creates between gender and genre. My research will indicate that the biker film belongs to the 'family tree' or lineage of the contemporary action film. This also has implications for our understanding of American cinema of the 1960s and 1970s, which is often known as New Hollywood. Specifically, I will show that the biker film's narration tends to be more post-classical than classical, largely because it often contains action sequences that disrupt the narrative. I will also demonstrate that the biker film can be read in conservative terms. This argument will make use of

\footnotetext{
${ }^{1}$ The titles for these films can be found in the filmography.

${ }^{2}$ Unless otherwise indicated, the term 'biker film' will be used in this thesis to describe the films made in the period of 1966-1974 specifically.

${ }^{3}$ Hark, I.R. "Fear of Flying: Yuppie Critique and the Buddy-Road Move in the 1980s." Cohan, S. and Hark, I.R. (eds.) The Road Movie Book. London and New York: Routledge, 1997. 227 (fn3.)
} 
Robert Ray's work on Right and Left film cycles in New Hollywood cinema. This also has connections to the ideological dimensions of the action film.

\section{Some Basics}

There is disagreement among biker film critics about how many of these films were made during this period. Jim Morton argues that before the 1970s "no fewer than fifteen biker films were released."4 Martin Rubin claims that there are about three dozen films in this cycle, ${ }^{5}$ while Allison Perlman contends that there were approximately forty movies released in this period. ${ }^{6}$ Andrew Syder argues that "over fifty 'chopper-operas' were unleashed onto cinema screens before the cycle ran out of gas in the early 1970s."7 The biker film contains exploitation elements and salacious qualities. These function in two ways. Firstly through the films' titles and marketing, and secondly through their narratives, especially in action sequences. As we have seen, the titles for these films are suggestive of a marginal and violent lifestyle. The action sequences of these films clearly display this violence and marginalisation. Biker films frequently include fight scenes, rape and sexual violence sequences, and drugtaking and party scenes. These features will be discussed in terms of exploitation cinema in chapter two.

The biker films of the 1960s and 1970s were made predominantly by independent production companies and studios. American International Pictures (AIP) produced twelve biker films during this period. ${ }^{8}$ Other independent studios linked with more than one biker film include Fanfare Films, which produced Hell's Angels on Wheels (1967), The Born Losers (1967), Angels from Hell (1968), Run Angel Run! (1969), and Nam's Angels (1970). Fanfare Films also distributed The Born Losers, Angels from Hell, Wild Wheels (1969), Run

\footnotetext{
${ }^{4}$ Morton, J. "Rebels of the Road: The Biker Film." Sargeant, J. and Watson, S. (eds.) Lost Highways. Creation Books, 1999. 62.

${ }^{5}$ Rubin, M. "Make Love Make War: Cultural Confusion and the Biker Film Cycle." Film History. Vol. 6, No. 3. (Autumn 1994.) 356.

${ }^{6}$ Perlman, A. "The Brief Ride of the Biker Movie." International Journal of Motorcycle Studies. March 2007. [online journal]. http://ijms.nova.edu/March2007/IJMS_Artcl.Perlman.html

${ }^{7}$ Syder, A. "Ripped from Today's Headlines: The Outlaw Biker Movie Cycle.” December 2002. [online journal]. http://www.scope.nottingham.ac.uk/article.php?issue=dec2002\&id=271\&section=article

${ }^{8}$ The AIP biker films are listed in the next chapter and in the filmography.
} 
Angel Run! and Nam's Angels. Meanwhile, Crown International Pictures produced The Wild Rebels (1967) and distributed The Hellcats (1967), The Wild Rebels and The Pink Angels (1971); Independent International Pictures (I-I) produced and distributed Satan's Sadists, Hell's Bloody Devils (1970), and distributed Angels' Wild Women (1972); AVCO Embassy Pictures produced C.C. and Company (1970) and distributed J.C. (1972); and New World Pictures produced Angels Hard as They Come (1971), Bury Me an Angel (1972), and distributed Angels Die Hard. It is worth noting that in several instances production companies made just a single biker film, which suggests that there was something opportunistic about this group of films.

Although these films were made by a variety of companies, there are some key creative figures in the biker film whose input spanned a number of films, as we might expect with genre films. For example, Al Adamson directed Hell's Bloody Devils, Angels' Wild Women and Satan's Sadists. Richard Rush directed both Hell's Angels on Wheels and The Savage Seven (1968). Maury Dexter directed The Mini-Skirt Mob (1968) and Hell's Belles (1969), and Lee Madden directed Hell's Angels '69 (1969) and Angel Unchained (1970). There were also actors who featured in a few biker films in this period, such as William Smith, a regular figure in the biker film. He appeared in Run Angel Run!, Angels Die Hard, Nam's Angels, C.C. and Company, and Chrome and Hot Leather (1971). Larry Bishop had roles as a biker in The Savage Seven, Angel Unchained, and Chrome and Hot Leather. Jack Starrett starred in The Born Losers, Hell's Bloody Devils, Nam's Angels, Hell's Angels on Wheels and Angels from Hellin these latter two films, he played the same character, police officer Bingham. Starrett also directed Run Angels Run! and Nam 's Angels. Jeremy Slate appeared in The Born Losers, The Mini-Skirt Mob, Hell's Belles, Hell's Angels '69, and Adam Roarke featured prominently in Hell's Angels on Wheels, The Savage Seven, Hell's Belles, and Nam's Angels. 
Many prominent figures in New Hollywood cinema worked in exploitation cinema at some point. ${ }^{9}$ For example, the biker film featured actors who later starred in several mainstream films. Three-time Academy Award winner Jack Nicholson features as both the anti-hero protagonist Poet in Hell's Angels on Wheels and as the antagonistic biker Bunny in Rebel Rousers (1970). Nicholson also acted in key New Hollywood films such as Easy Rider (1969) and Five Easy Pieces (1970) during the same period. Bruce Dern played a 'good' biker in Rebel Rousers and a sadistic motorcycle rider in The Cycle Savages (1969). Peter Fonda was also an important figure in the biker film, even though he only appeared in The Wild Angels. Fonda is significant because his role as Heavenly Blues in The Wild Angels seems to influence the character of Wyatt or 'Captain America' in Easy Rider. Dennis Hopper can be viewed in a similar way, because he also features in both a biker film (The Glory Stompers, 1968) and Easy Rider. Other well known actors who appeared in biker films include John Cassavettes (Devil's Angels, 1967); Russ Tamblyn (Satan's Sadists); AnnMargret (C.C. and Company); Scott Glenn, and Gary Busey (both Angels Hard as They Come).

\section{Earlier Examples}

There are a number of cinematic antecedents of the 1960s and 1970s biker film. The Wild One (1953) is often considered to be the first biker film made in the post-war period. ${ }^{10}$ The film follows leather-clad biker Johnny (Marlon Brando) and his biker gang as they invade a rural town and begin causing trouble, which escalates after a rival gang, The Beetles, arrives. The film deals with the themes of youth rebellion and juvenile delinquency, which is expressed both through the bikers' restless mobility ${ }^{11}$ and Johnny's "moody anti-authoritarianism." 12 The later biker film shares these attributes. Daniel Biltereyst argues that The Wild One was a film that was "part of a wider flow of highly confrontational,

\footnotetext{
${ }^{9}$ See McDonagh, M. "The Exploitation Generation. Or: How Marginal Movies Came in from the Cold." Elsaesser, T., Horwath, A. and King, N. (eds.) The Last Great American Picture Show: New Hollywood Cinema in the 1970s. Amsterdam: Amsterdam University Press, 2004. 107-130.

${ }^{10}$ Schwartz, R.A. The 1950s. New York: Facts on File, 2003. 221.

${ }^{11}$ Laderman, D. Driving Visions: Exploring the Road Movie. Austin: University of Texas Press, 2002. 45.

${ }^{12}$ Fulwood, N. One Hundred Violent Films That Changed Cinema. London: Batsford, 2003. 26.
} 
more violent, and openly antisocial movies that either reflected a dangerous social reality or were thought to stimulate the same." ${ }^{\prime 13}$ These themes of violence and anti-authoritarianism are also found in the biker film. Even though Martin Rubin argues that The Wild One did not inspire a cycle, or succession, of subsequent biker films in the 1950s, the film's anti-authoritarian tone and sense of danger nonetheless became a template for the more violent and reactionary biker films in the 1960s and 1970s. ${ }^{14}$

Motorcycle Gang appeared in 1957. The film is linked to the later biker films because it was produced by AIP, and contains some of the fight scenes and conflict that typify the later biker film. However, Bill Osgerby argues that although "AIP sought to reproduce the dangerous allure of The Wild One...[Motorcycle Gang] lacked the noir-esque elements that gave The Wild One its edge." 15 The film is nonetheless linked with The Wild One through the similar use of iconography. For example, both films depict 1950s bikers wearing leather, which is an example of what David Laderman calls "motorcycle fetishism."16 This type of costuming also features in subsequent films featuring bikers, such as in the Beach Party films and most notably in Scorpio Rising (1964).

The AIP-produced Beach Party films are important to discuss here because although their narratives are not necessarily about the biker lifestyle, they nonetheless feature a motorcycle gang called the "Rats" and "Mice." This gang and/or its leader Eric von Zipper - played by Harvey Lembeck - appear in seven Beach Party films. ${ }^{17}$ The gang is the antagonistic force in these films. However, they are mainly portrayed as inept, "blundering" comic characters,

\footnotetext{
${ }^{13}$ Biltereyst, D. “American Juvenile Delinquency Movies and the European Censors: The Cross-Cultural Reception and Censorship of The Wild One, Blackboard Jungle, and Rebel Without a Cause." Shary, T. and Seibel, A. (eds.) Youth Culture in Global Cinema. Austin: University of Texas Press, 2007. 12.

${ }^{14}$ Rubin, M., 360.

${ }^{15}$ Osgerby, B. "Sleazy Riders; Exploitation, "Otherness," and Transgression in the 1960s Biker Movie." Journal of Popular Film and Television. Vol. 31, No. 3. (Fall 2003.) 100.

${ }^{16}$ Laderman, 286.

17 These include Beach Party (1963), Bikini Beach (1964), Pajama Party (1964), Beach Blanket Bingo (1965), How to Stuff a Wild Bikini (1965), Dr. Goldfoot and the Bikini Machine (1965), and The Ghost in the Invisible Bikini (1966).
} 
unlike their more menacing, violent counterparts in later biker films. ${ }^{18}$ The Rats and Mice also seem to be a parody of Johnny's gang in The Wild One. This is most apparent in their costume, which includes black leather jackets and caps. Osgerby argues that the Rats and Mice are an "emblem of outdated rebellion - a symbol of generational revolt configured as ludicrously passé against the goodtime hedonism of the surf set." 19

Kenneth Anger's 1964 underground experimental film Scorpio Rising gives the biker story and its characters a homoerotic dimension. Anger's film uses images of leather-clad bikers and various provocative camera shots, such as close-ups on male body parts - including the torso and crotch of the protagonist when he is getting dressed. There is also an emphasis on things such as leather clothing and chrome exhaust pipes, which are used to situate biker subculture in homoerotic terms. This film also contains Nazi and fascist imagery, such as swastikas and images of Hitler. ${ }^{20}$ This Nazi symbolism has an interesting corollary in the 1960s and 1970s biker film, as the later films also contain such fascist iconography as swastikas, German iron crosses and Luftwaffe insignia. This issue will be dealt with in chapter four. The use of a popular rock soundtrack in Scorpio Rising, including songs such as 'Blue Velvet' and 'Wipe Out,' is another link with the later biker films, which also feature popular music on their soundtracks.

Russ Meyer's Motorpsycho is an exploitation film made in 1965, a year before The Wild Angels was released. The film is interesting because it seems to have some of the narrative and thematic ingredients found in the biker film cycle. In terms of the similarities, Klinger argues that the film "seems to exhibit the same kind of repulsed fascination for the Hell's Angels that gripped journalist Hunter S. Thompson in a similar time and place." ${ }^{21}$ Osgerby contends that Motorpsycho chronicled "the trail of rape and murder left by a trio of malevolent bikers." 22

\footnotetext{
${ }^{18}$ Osgerby, 100.

19 Ibid.

${ }^{20}$ Mills, K. The Road Story and the Rebel: Moving Through Film, Fiction and Television. Carbondale: Southern Illinois University Press, 2006. 114.

${ }^{21}$ Klinger, B. "The Road to Dystopia: Landscaping the Nation in Easy Rider." Cohan, S. and Hark, I.R. (eds.) The Road Movie Book. London and New York: Routledge, 1997. 177.

${ }^{22}$ Osgerby, 103.
} 
The film follows a trio of dangerous, threatening bikers and contains some of the elements that helped give the subsequent biker films their notoriety. However, it differs from the later biker film because it is not about a gang, and instead focuses on just three bikers, and its treatment of physical and sexual violence is not as explicit as in the later biker film. Motorpsycho is also mostly neglected by the biker film critics, who treat The Wild Angels as the first biker film in the group of films analysed in this project. It is for these reasons that I have chosen not to discuss the film further.

\section{Easy Rider}

Easy Rider is an important film to discuss here because it was arguably the most well-known film with bikers from this period. I will argue that although Easy Rider involves men riding motorcycles, the film seems to be more of a road movie than a biker film. Easy Rider follows the journey of two motorcycleriding hippies as they travel across America towards the Mardi Gras festival in New Orleans. Geoff King argues that Easy Rider was a significant film of the late 1960s because it "marked a point at which this kind of filmmaking crossed over into the Hollywood mainstream." 23 The film was successful at the box office, earning up to $\$ 60$ million, from a production budget of $\$ 500,000 .{ }^{24}$ Easy Rider was also important because it addressed a 'youth' audience. King maintains that Easy Rider appealed to young people because it celebrated the counterculture and focused on youth rebellion. ${ }^{25}$ As Mills argues, "Easy Rider not only proved the profitability of youth-oriented, low-budget films, but also, importantly, demonstrated the ongoing power and deep appeal of the road story as a genre of youthful rebellion." 26 In terms of production, Easy Rider also provides an alternative model to expensive, unsuccessful mainstream productions. This is firstly because it was an independent film, ${ }^{27}$ and secondly

\footnotetext{
${ }^{23}$ King, G. New Hollywood Cinema: An Introduction. New York: Columbia University Press, 2002. 12-13.

${ }^{24}$ Lev, P. American Films of the 70s: Conflicting Visions. Austin: University of Texas Press, 2000. 5; King, G. (2002), 12.

${ }^{25}$ King, G. (2002), 17.

${ }^{26}$ Mills, 125.

${ }^{27}$ Monaco, P. The History of American Cinema: The Sixties 1960-1969. New York and Detroit: Charles Scribner's Sons, 2001. 29-30; Hill, L. Easy Rider. London: BFI Publishing, 1996. 10; Roberts, S. "Western Meets Eastwood: Genre and Gender on the Road." Cohan, S. and Hark, I.R. (eds.) The Road Movie Book. London and New York: Routledge, 1997. 51.
} 
because it involved younger, creative personnel, such as Dennis Hopper and Peter Fonda. Easy Rider "catalyzed the New Hollywood revolution of young auteurs in the early 1970s, a time when many of America's most famous contemporary directors established their reputations through road films." 28 These directors include Francis Ford Coppola (The Rain People, 1969), Steven Spielberg (Duel, 1971), and Martin Scorsese (Boxcar Bertha, 1972).

Easy Rider has also been read in ideological terms by critics. The film functions as a kind of 1960s social commentary in two ways. The first is through the film's narrative, which highlights the conflict between progressive and conservative characters and their respective lifestyle. Klinger argues that this has much to do with the film's exploration of American regionalism, which is politicized through the journey of the protagonists. ${ }^{29}$ For example,

In the Southwest, the protagonists enjoy the freedom of the road, the hospitality of those they encounter, and the beauty and mystery of the region's wilderness. Conversely, the South, the small-town South in particular, is demonized in Easy Rider as the region most identified in the 1960s with militant ignorance, racism and violence. ${ }^{30}$

This is perhaps best emphasised in the diner scene when Billy, Wyatt and George stop in a rural town. They are mocked and subtly threatened by some locals, who then attack the bikers with baseball bats that night when they are asleep at their campsite, resulting in George's death.

The second way in which Easy Rider functions as a social commentary of the 1960 s is through its observation of contemporary American life. ${ }^{31}$ Klinger argues that this is evident through the film's treatment of the road, which "appears to generate a clear-cut countercultural message about the state of the nation in the late 1960s." ${ }^{32}$ Again, this is perhaps most apparent in Easy Rider when the bikers reach the South. Here, the film does not depict images of a romanticised rural landscape as it did earlier in the film in relation to the

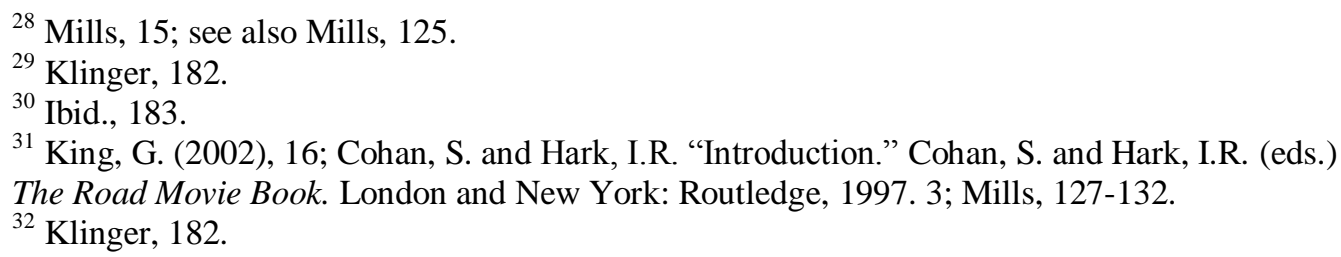


Southwest. Instead it focuses on people, specifically African-Americans, and poverty. As Klinger argues, "While there are idyllic images of cypress trees and the Old South, Southern scenery is dotted with African-American poverty and the intrusive icons of modern life and industrialization (gas stations, refineries, etc.).,

However, this thesis will not discuss Easy Rider in depth because there are some fundamental differences between it and biker films. For example, Easy Rider is not about motorcycle gangs. Instead, it only focuses on two characters who ride motorcycles. There is also a difference in the treatment of mobility in these films. Billy and Wyatt travel further than the biker gangs, which makes Easy Rider appear more open-ended. While the gangs in biker films move around when they are on a 'run,' their journeys are generally much shorter and more purposeful. I return to this issue below.

Another reason why I am not discussing Easy Rider as a biker film is because it can be positioned differently in ideological terms. For example, Easy Rider is a Left wing cycle film that articulates progressive concerns associated with the counterculture. This differentiates it from the biker film, because biker films can be interpreted as Right cycle films because of the relationship between gender and violence in them. In this respect, the biker film can instead be associated with other New Hollywood Right cycle films such as the police thriller or 1980s action films. These issues will be raised further in chapter four.

\section{The Road Movie}

Because Easy Rider is considered part of the road movie genre, it is important to examine the road movie more broadly. Road movies are better known and have received more critical analysis than biker films. There are both similarities and differences between these genres. These issues largely concern narrative and how the films can be situated politically. The road movie has been defined through its focus on movement through space, specifically automobile mobility, or 'automobility.' Laderman defines the road movie as a genre about

\footnotetext{
${ }^{33}$ Ibid., 183.
} 
travelling, ${ }^{34}$ and Brian Ireland argues that a key feature of the road narrative is "geographical movement." 35 This mobility is often linked to quest and escape narrative forms. ${ }^{36}$ Laderman argues that the 'quest' road movie narrative concentrates on a physical, and arguably psychological, search or movement toward something. By contrast, the 'outlaw' road movie signals a journey or escape from something, such as society or authority. ${ }^{37}$ Julian Stringer concurs with Laderman, claiming that:

The road movie habitually promotes two narrative situations...In the first, one or more goal-orientated protagonists take off as a means to escape, either from pursuers...or from a hitherto boring lifestyle...In the second, one or more protagonists seek to "find themselves" existentially, either through sex...violence... or by messing with nature. ${ }^{38}$

Quest narratives emphasise roaming, and focus on a journey that is one of discovery, or self-discovery. ${ }^{39}$ This type of narrative "drives many protagonists of the road movie, as they travel in search of a better future, a new life, or greater potentialities." 40 The characters' 'goal' in the quest road movie may also be to drift around, in which he/she does not need to be partial to anyone or anything, such as in Five Easy Pieces, The Rain People and Two-Lane Blacktop (1971).

Laderman's 'outlaw' road movie narrative, on the other hand, usually involves its main characters fleeing from authority after committing a crime or injustice. Mills argues that "taking to the road as a form of escape is... a venerable plot device." ${ }^{, 1}$ The characters remain on the run until the end of the narrative, in which they are either killed or captured. This kind of pretext is found in road movies that focus on the outlaw couple, such as Bonnie and Clyde (1967),

\footnotetext{
${ }^{34}$ Laderman, 14.

${ }^{35}$ Ireland, B. "American Highways: Recurring Images and Themes of the Road Genre." The Journal of American Culture. Vol. 26, No. 4. (December 2003.) 475.

${ }^{36}$ Laderman, 20.

37 Ibid.

${ }^{38}$ Stringer, J. 'Exposing Intimacy in Russ Meyer's Motorpsycho! and Faster Pussycat! Kill! Kill!." Cohan, S. and Hark, I.R. (eds.) The Road Movie Book. London and New York: Routledge, 1997. 165.

${ }^{39}$ Laderman, 20.

${ }^{40}$ Sargeant, J. and Watson, S. "Introduction.” Sargeant, J. and Watson, S. (eds.) Lost Highways: An Illustrated History of Road Movies. London: Creation, 1999. 16.

${ }^{41}$ Mills, 209.
} 
Badlands (1973), Thieves Like Us (1974) and Dirty Mary, Crazy Larry (1974).

Characters in the outlaw road movie may also seek an escape from their domestic or work life, such as Bonnie in Bonnie and Clyde and Holly in Badlands. The outlaw road movie usually also ends with the death and tragedy of its main characters.

The narrative structure of the road movie is marked by looser causality, especially in the quest film. This is important because it is also a feature of the biker film. The lack of character goals and/or motivation has a corollary in the episodic quality of many road movies.

In the countless road movies that have followed Easy Rider, the protagonists rarely arrive at their destination or find what they are seeking. The diversions and sidetracks become ends in themselves and the original inspiration for hitting the road is lost or irreparably fragmented. ${ }^{42}$ There was a distinct lack of drive and purpose in both the narratives and characters of the films in the 1970s, including the road movie. ${ }^{43}$ Thomas Elsaesser maintains that "journeys are no longer the same drive- and goalorientated moral trajectories they once were." ${ }^{44}$ Instead, these films often concern characters who engage in an "existential meandering." Two-Lane Blacktop has "nearly no dialogue or character motivation. In terms of plot, the quest (a race across country) gradually loses coherence, literally disintegrating at the film's infamous ending."46

The episodic structures of road movies can also be linked to violence. This is particularly evident in the outlaw road movie. Shari Roberts argues that death and violence permeate the road movie. ${ }^{47}$ As Michael Atkinson maintains, "road movies are cowled in lurking menace, spontaneous mayhem and dead-end fatalism, never more than a few roadstops away from abject lawlessness and

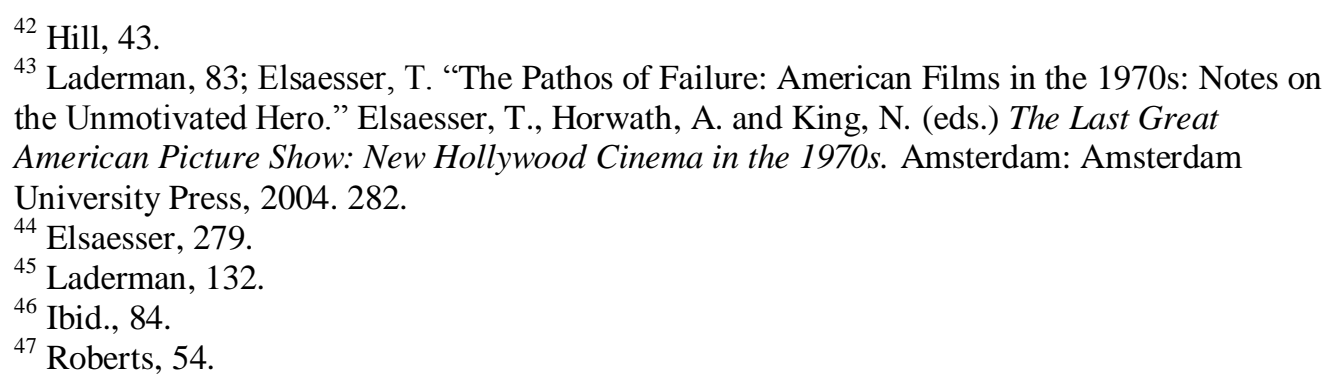


haphazard bloodletting., ${ }^{, 48}$ Corey K. Creekmur argues that this violence is common within the road movie genre, and that outlaw couple films "proceed by a pattern of escalation, building from..."small” crimes, to lengthy scenes of...action-packed slaughter...from armed robbery to murder, and from efficient little capers to messy bloodbaths." 49 This trend has similarities to biker films because they contain large amounts of physical and sexual violence. Such violence also makes the structures of these films appear episodic.

The 'spectacular' quality of road movies is also evident through visual style. In terms of style, road movies are influenced to some extent by the films of postwar European art cinema. Jonathan Rosenbaum claims of films of the 1960s, including the road movie: "the titillating effect of...their stylistic eclecticism...point[s] to the...inroads made by New Wave films on Hollywood thinking and practices. ${ }^{, 50}$ Laderman claims that "elliptical narrative structure and self-reflexive devices; elusive development of alienated characters; bold travelling shots and montage sequences" found in the road movie are all borrowed from the European art film. ${ }^{51}$ Devices such as the travelling, tracking and POV shot had a kinetic effect. The travelling shot enables characters and/or the audience to observe the surroundings or engage in contemplation, as well as heightening the 'thrill' that this vehicle mobility exhibits. For example, the first getaway scene in Bonnie and Clyde incorporates "eye-level travelling shots from the backseat, intercut with various high-angle shots, encourage viewer identification with the spectacle of their getaway," 52 as does the final police chase in Badlands, which features a montage comprised of many crosscutting and travelling shots. Vanishing Point (1971) is another road movie that uses travelling shots and driving montages to exhibit visceral thrills, such as in the

\footnotetext{
${ }^{48}$ Atkinson, M. "Crossing the Frontiers." Sight and Sound 1. 1994. 16 - also quoted in Cohan and Hark, 1.

${ }^{49}$ Creekmur, C.K. "On the Run and On the Road: Fame and the Outlaw Couple in American Cinema." Cohan, S. and Hark, I.R. (eds.) The Road Movie Book. London and New York: Routledge, 1997. 95.

${ }^{50}$ Rosenbaum, J. "New Hollywood and the Sixties Melting Pot." Elsaesser, T., Horwath, A. and King, N. (eds.) The Last Great American Picture Show: New Hollywood Cinema in the 1970s. Amsterdam: Amsterdam University Press, 2004. 140.

${ }^{51}$ Laderman, 5.

52 Ibid., 52.
} 
film's cross-country police chase. ${ }^{53}$ The tracking shot involves mobile camera capturing motion, which, as Laderman argues, "attempt to convey a visceral sense of travelling at a hyperhuman, modernized speed." also found in the biker film's riding sequences.

In thematic terms, both the biker film and the road movie have an antiauthoritarian quality. Laderman claims that "the fundamental core impulse of the road movie [is] rebellion against social norms." 55 Road movies characters are also involved in unconventional, even anti-social behaviour, as are the biker film characters. Characters in both kinds of films defy American society and authority, and reject (conservative) norms such as a stable job and domesticity. The bikers in biker films also live a non-conformist, marginalised lifestyle, but it is noticeably more violent than in road movies.

However, there are also differences between the biker film and the road movie. The biker film features more groups, whereas road movies usually feature only up to three main characters who are travelling. The characters in the biker film do not travel long distances, and usually their destinations are more mundane and the trips are less interesting. The biker film is also less about a personal quest than the road movie. The biker film and the outlaw road movie both contain violence sequences. The level of violence, its casual nature in the biker film, and the presence of sexual violence in the biker film differentiate the films from one another. The biker film tends to be more episodic than the road movie because of the emphasis on physical and sexual violence in the former. These types of scenes give the biker films 'exploitation' qualities. This will be discussed further in the next chapter.

Even though some biker films, such as The Wild Angels, presented "a confusing mixture of 'leftist' and 'right-wing' elements," as I argued earlier the biker film

\footnotetext{
${ }^{53}$ Other camera techniques incorporated into the road movie narrative, but which maybe do not have as such generic significance as the travelling shots, are long shots (usually of the desert) and the incorporation of framing devices within the car itself such as the rear-view mirrors and windows.

${ }^{54}$ Laderman, 15.

55 Ibid., 1.
} 
largely belongs to the Right film cycle. ${ }^{56}$ It features biker characters who are violent, misogynistic and anti-social. By contrast, the road movie characters' affinity with countercultural perspectives and appeal to the youth audience provides it with a progressive dimension. This will be discussed further in chapter four.

\section{The Critical Reception of the Biker Film}

The critics of the road movie tend to neglect the biker film. For example, Laderman and Klinger discuss the biker film briefly. Laderman argues that the biker films such as The Wild One and The Wild Angels can be seen to be a "bridge" to the road movie because they have thematic elements such as the subversion of American institutions and the reflections of the "bohemian hippie spirit" of the counterculture in the 1960s. ${ }^{57}$ However, both The Wild One and The Wild Angels are not road movies because they take place in locations where "stability - the lack of movement - is emphasized." 58 Even though the biker gang in The Wild Angels do journey to and from different locations, "the film's articulation of travelling is more implied than explicit." ${ }^{, 59}$ Mills similarly argues that while "biker films are not really road films per se," they are linked through "cycling between rebellion and commodification." ${ }^{60}$ Klinger contends that both the road movie and the biker film are tied to "tropes of the counter-culture, from libidinous pleasure, spontaneity, and rebellion to aesthetic hipness." ${ }^{61}$ Although she indicates that in Easy Rider there are allusions to the biker film, she only mentions the genre briefly.

There are, however, a small number of detailed discussions of the biker film. The four main biker film critics are Martin Rubin, Bill Osgerby, Andrew Syder, and Allison Perlman. They often give similar accounts of the biker film, by focusing their articles primarily on the historical and cultural contexts in which

\footnotetext{
${ }^{56}$ Horwath, A. "A Walking Contradiction (Partly Truth and Partly Fiction)." Elsaesser, T., Horwath, A. and King, N. (eds.) The Last Great American Picture Show: New Hollywood Cinema in the 1970s. Amsterdam: Amsterdam University Press, 2004. 83.

${ }^{57}$ Laderman, 47.

${ }^{58}$ Ibid.

${ }^{59}$ Ibid., 48.

${ }^{60}$ Mills, 116-117.

${ }^{61}$ Klinger, 180.
} 
these films were made. Other critics who have written on these films include Jim Morton, Mike Seate in his book Two Wheels on Two Reels, and John Wooley and Michael H. Price, in their book The Big Book of Biker Flicks. These latter critics tend to give factual information about the biker film, rather than textual or socio-cultural analysis.

Each of the four main biker film critics gives a pre-history of the biker film in terms of reading the Hell's Angels and the media attention surrounding this gang. They also detail several major traits of the biker film, such as antiauthoritarianism, violence, and rape. They all argue that Easy Rider was an important film in relation to this genre, as well as highlighting the biker film's associations with the Western.

Rubin's main argument is that there is a clash of cultural signs in the biker film, which thus creates a cultural and ideological uncertainty in these films, that Rubin calls "cultural confusion." 62 This is because "[t]he biker film cycle filled an equivocal but viable position at a time when the interrelated areas of generation, filmmaking categories and audience composition were exceptionally fluid and ambivalent. ${ }^{, 63}$ Rubin also argues that the configuration of the characters in these films often fluctuates between biker and non-biker protagonists: "The primary method of classifying these films is in terms of whether the protagonist is a biker or a non-biker." ${ }^{, 64}$ If the protagonist is a nonbiker, he claims, then the biker gang is usually configured as the antagonistic force in the film; but if the protagonist is a biker then a common "configuration has the biker protagonist participating with his gang in a morally clouded struggle against the civilian world." ${ }^{65}$ However, Rubin maintains that "[a] more common configuration has a biker in the in-between position," which emphasizes both the biker's isolation from the rest of his gang, and the conflict between him and his gang. ${ }^{66}$ Rubin also associates the biker film with

\footnotetext{
${ }^{62}$ Rubin, M., 355.

${ }^{63}$ Ibid., 377.

${ }^{64}$ Ibid., 362.

65 Ibid.

${ }^{66}$ Ibid., 363.
} 
exploitation and art cinema, as well as the drive-in circuit. These issues will be discussed further in the next chapter.

Osgerby argues that biker films "gave ambivalent treatment to the outlaw biker mythology." ${ }^{, 67}$ Osgerby claims that on the one hand, "the marauding motorcycle gang was presented as chilling evidence of a collapsing social order.",68

However, on the other hand, "the biker movies reveled in their antiheroes' flouting of mainstream values, with an emphasis on transgressive difference that effectively effaced the divide between commercial exploitation and avant-garde experiment." ${ }^{, 69}$ Osgerby discusses the biker film in terms of both spectacle and rebellion. He emphasises the connections between exploitation cinema and the biker film's pre-history. Osgerby raises some issues regarding the spectacle in these films as being similar to the spectacle found in the early days of cinema, which will be analysed further in chapter three.

Syder also reiterates Rubin and Osgerby's arguments that the biker film treats its key characters ambiguously: "In most biker films, it is unclear whether we should revile or celebrate the outlaw motorcycle gangs." ${ }^{, 70}$ One of Syder's main arguments is that the biker gang press reports can be blended with the Western genre in order to identify some primary components of the biker film. ${ }^{71}$ These include "how bikers are configured as outlaws...the relationship between bikers and the small towns they invade...the relationship between bikers and modern cities and technology; and...the representation of movement and travel."72

Perlman's article gives largely historical accounts of the biker film and contains information already supplied by the other biker film critics. She looks at the origins of the biker film, with an emphasis on real biker gangs and cinematic precursors such as The Wild One. The majority of Perlman's article discusses the biker film's associations with the Western genre, particularly through issues such as moral ambiguity, violence and the treatment of women. She also

\footnotetext{
${ }^{67}$ Osgerby, 98.

${ }^{68}$ Ibid.

69 Ibid.

${ }^{70}$ See Syder.

${ }^{71}$ Ibid.

${ }^{72}$ Ibid.
} 
considers the links between the biker film, the Western and the road movie Easy Rider. These issues will be dealt with in this thesis.

There are also some problems in the biker film critics' work. Their arguments seem to be lacking comprehensive textual analysis, and they only provide a small number of films as examples to support their arguments and assertions. Rubin, for example, does not use many biker film examples in his analysis and instead tends to list the examples he does provide. Perhaps surprisingly, the biker film critics do not link the biker film to the genealogy of the action film, which is an issue I will focus on in chapter four. The biker film critics also do not discuss the narratives, or narrative structures, of these films in comprehensive detail. Instead, they tend to just relay story information. This gap provides an opportunity for more sustained analysis of the narrative structures of biker films in chapter three.

\section{Thesis Structure}

Chapter two will examine the arguments of biker film critics in more detail. I will also situate the biker film within the context of New Hollywood cinema by discussing social, cultural, industrial and audience issues. In chapter three I will assess the extent to which the biker film uses classical or postclassical narration. In chapter four I aim to show that the biker film should be treated as part of the lineage, or genealogy, of the action film. This is closely tied to the issue of gender. This chapter will enable me to position the biker film in ideological terms. In the conclusion I will show that although the biker film starts to disappear in the early 1970s, that there are other films featuring bikers that occur after this cycle dies out. I will explore whether these fit the model of the 1960s and 1970s biker film discussed in this thesis. I will also use some examples from both film and television as possible allegories for this disappearance. 


\section{Introduction}

This chapter will place the biker film in a number of contexts. This will be done by examining the various cultural, production and exhibition factors surrounding these films. We will consider the postwar media panics surrounding real life biker gangs such as the Hell's Angels; the cultural alliance formed between real life bikers and hippie members of the 1960s counterculture; and the changing audiences and industrial situations in New Hollywood cinema. This chapter will use the biker film critics as well as a range of other writers on both film and social history to help shape this analysis. My analysis will show that the biker film is a hybrid, both culturally and in terms of genre. This makes it difficult to place it in any one area or category definitively. This chapter will thus act as both a social history and as a literature review.

\section{Media Panics and Real Gangs}

Writers on the biker film have commented on the links between actual biker gangs, the media coverage they received and the representations of bikers in the biker film. There was a lot of press coverage surrounding the biker gangs in postwar America. This was especially significant in the 1960s, when the public image of gangs such as the Hell's Angels was largely negative and fearful. During this period, they were considered to be what Stanley Cohen calls "folk devils" in a larger societal "moral panic." 73 This section of the chapter will argue that the press stories and their content are implicitly connected to the biker film, because the same kind of lurid behaviour and scenarios featured in the press stories are also exhibited and exploited through scenes of sexual and physical violence, with the same negative representation of the biker gang's anti-authoritarian lifestyle. This includes what Martin Rubin argues as being the two most prominent and durable themes of biker mythology: the invasion of the small, rural American town, and rape - especially gang rape. ${ }^{74}$ The connections

\footnotetext{
${ }^{73}$ Cohen, S. Folk Devils and Moral Panics: The Creation of the Mods and Rockers. London: MacGibbon and Kee, 1972. 1.

${ }^{74}$ Rubin, M. "Make Love Make War: Cultural Confusion and the Biker Film Cycle." Film History. Vol. 6, No. 3. (Autumn 1994.) 359-360.
} 
made between the biker press stories in the mainstream media and the biker film arguably lends these films something of a realist or documentary quality.

There were a number of incidents featuring biker gangs that were documented and reported in the postwar period by the press. This press coverage largely presented a negative and fearful image of the biker gang in the public's minds through the lurid nature of the incidents depicted, thus establishing them as a 'moral panic.' Cohen defines a 'moral panic' as when '[a] condition, episode, person or group of persons emerges to become defined as a threat to societal values and interests." ${ }^{, 75}$ Michael Brake likens the biker media attention and 'moral panic' of the biker gangs to the same kind of panic surrounding British youth in the same period, in which there was substantial "deviancy amplification" by the press and mass media over what was actually only a very little amount of destruction and violence caused, in this instance, by British youths on a beach. ${ }^{76}$

Biker film critics argue that the negative publicity influenced the biker gangs' image as "savage monsters." 77 Bikers were deemed a great threat to civilised and orderly society and the subject of a moral panic. This corresponds with Hunter S. Thompson's claim that the Hell's Angels had become the "enemies of society" due to negative media coverage. ${ }^{78}$ The press presented the public with images of biker gangs "parading in brazen, ear-splitting effrontery down Main Street while decent folk cower behind their shattered windows, and the image of a screaming virgin being dragged into a welter of slavering hoodlums." ${ }^{79}$ Rubin maintains that biker gangs "raped and pillaged their way through small-town California like a horde of modern-day barbarians." ${ }^{80}$ The biker film critics are not alone in their claims, as a similar image of biker gangs is shared by other

\footnotetext{
${ }^{75}$ Cohen, 1.

${ }^{76}$ Brake, M. Comparative Youth Culture: The Sociology of Youth Cultures and Youth Subcultures in America, Britain and Canada. London and New York: Routledge \& Kegan Paul, 1985. 64.

77 Osgerby, B. 'Sleazy Riders; Exploitation, 'Otherness,' and Transgression in the 1960s Biker Movie.” Journal of Popular Film and Television. Vol. 31, No. 3. (Fall 2003.) 101.

${ }^{78}$ Thompson, H. "Hell's Angels: Hoodlum Circus and Statutory Rape of Bass Lake." Douglas, J.D. (ed.) Observations of Deviance. New York: Random House, 1970. 131.

${ }^{79}$ Rubin, M., 362.

${ }^{80}$ Ibid., 355.
} 
writers and critics of the period, who contend that the image of real life biker gangs was closely associated with danger and violence. ${ }^{81}$ Mitch Librett argues that "true outlaw bikers are often perceived as a menacing, lumpen, and exceedingly dangerous phenomenon - prone to gratuitous, expressive acts of violence, and heavily involved in organized criminal activity."

Starting in the post-war years and culminating in the 1960s, the biker gang cultural stereotype became widespread and well known. Biker gangs were exploited as the subjects of feature stories in many prominent newspapers, magazines and other publications such as the Nation, Time, Newsweek and the New York Times. ${ }^{83}$ This sensationalism made biker gangs a suitable topic for exploitation cinema, which I will discuss below. The 1947 motorcycle rally in Hollister, California is one such incident that presents a negative representation of the real life biker gang in the mainstream press. The Hollister incident is considered to be, in terms of chronology, the first event in which the image of the biker gang and lifestyle was documented in the mainstream media in the post-war period, and was the event in which biker gangs became widely regarded as "a new form of social menace." ${ }^{84}$ During this episode, Rubin claims that two biker gangs assaulted common decency by taking over the town, "looting, brawling, intimidating citizens, turning the main street into a drag strip, and overwhelming the local police." 85 The Hollister incident arguably provides the image template for the biker image and mythology in terms of documenting and representing the town-sacking theme. A motorcycle rally in Riverside, California in 1948 - an incident in which one person died - cemented the negative image of the biker gang as small-town invaders in eyes of both the public and the media. ${ }^{86}$ The town-sacking theme then formed the basis of the

\footnotetext{
${ }^{81}$ Thompson (1970), 131; see also Hendley, N. American Gangsters, Then and Now. Santa Barbara, Denver and London: ABC-CLIO, 2010. 7.

${ }^{82}$ Librett, M. "Outlaw Bikers." Kontos, L. and Brotherton, D. (eds.) Encyclopedia of Gangs.

Westport, CT: Greenwood Publishing Group, 2008. 182.

${ }^{83}$ Mills, K. The Road Story and the Rebel: Moving Through Film, Fiction and Television. Carbondale: Southern Illinois University Press, 2006. 116.

${ }^{84}$ Syder, A. "Ripped from Today's Headlines: The Outlaw Biker Movie Cycle." December 2002. [online journal]. http://www.scope.nottingham.ac.uk/article.php?issue=dec2002\&id=271\&section=article ${ }^{85}$ Rubin, M., 359.

${ }^{86}$ Mallory, S.L. Understanding Organized Crime. Sudbury, MA, Mississauga, Ontario and London: Jones and Bartlett Publishers, 2007. 152.
} 
publication Cyclists' Raid in 1951, a fictional publication focusing on the transgressive behaviour of biker gangs. ${ }^{87}$

Perlman argues, "the press coverage was particular fascinated with the Angels' deviant sexual proclivities, from gang rape and orgies to the alleged trading and selling of women." ${ }^{88}$ In 1964 a number of Hell's Angels were arrested for the alleged gang rape of two local women after a party in Monterey. ${ }^{89}$ This incident arguably influenced public perception about the link between biker gangs and sexual violence. It prompted an investigation into biker gangs by California State Senator Fred Farr, which resulted in the creation of the 1965 Lynch report, a study of biker gangs that Syder describes as being a "government exposé of the filthiest biker exploits." 90 The Lynch report again prompted a wave of media coverage surrounding the Hell's Angels and other biker gangs, who had now become "synonymous with mainstream America's murkiest fears", because it detailed "a lurid litany of outrage committed by assorted biker gangs." Morton similarly regards the Lynch Report as depicting biker gangs as "unwashed thugs" who wreaked havoc on America's highways, especially in California. ${ }^{92}$ The biker film critics are not alone in their arguments regarding the Lynch report. Thompson also saw the Lynch report as a "gory account of innumerable instances of violence and rape among the Angels." ${ }^{93}$ Following the Lynch report and a number of other articles in, for example, the Saturday Evening Post and Life, the biker gang's negative reputation reached a peak and had "people of the Far West looking to each weekend in the Angels' life as an invasion by baby-raping Huns."94 The Lynch report was therefore a significant and pivotal publication in terms of sustaining the image of the Hell's Angels and other biker gangs as the target of a 'moral panic.'

\footnotetext{
${ }^{87}$ Rubin, M., 360.

${ }^{88}$ Perlman, A. "The Brief Ride of the Biker Movie." International Journal of Motorcycle Studies. March 2007. [online journal].

http://ijms.nova.edu/March2007/IJMS_Artcl.Perlman.html

${ }^{89}$ Osgerby, 101.

${ }^{90}$ See Syder.

${ }^{91}$ Osgerby, 100-101.

${ }^{92}$ Morton, J. "Rebels of the Road: The Biker Film." Sargeant, J. and Watson, S. (eds.) Lost

Highways. Creation Books, 1999. 57.

93 Thompson (1970), 131.

${ }^{94}$ Wolfe, T. The Electric Kool-Aid Acid Test. London: Black Swan, 1968. 152.
} 
However, the biker film critics appear to be somewhat selective in their summarizing of biker events in the post-war period, because they do not mention some incidents that Thompson describes in his chapter on the "rape mania" surrounding the Hell's Angels during the mid-1960s. The alleged events that Thompson describes include a rape in Clovis, California, a 1966 trial of some Hell's Angels for another 'rape' in Sonoma County, and a rape in an Oakland bar. ${ }^{95}$ Even though the biker film critics allude to rape being an inherent part of the biker image and lifestyle, they do not give extensive examples of where this theme arises in the mass media of the 1960s, and thus their analysis on this common biker theme in post-war American social history is perhaps not as comprehensive as it could be.

Even though there was a lot of press coverage surrounding these gangs at the time, both the biker film critics and wider critics have argued that these press reports appear to be exaggerated, dubious, and in some cases, fictional. This corresponds with Brake's discussion on British youth, in which some stories about 1960s British subcultures such as the Mods and the Rockers were "greatly exaggerated," but "societal reaction was definite" nonetheless. ${ }^{96}$ In terms of the postwar biker gang, Katie Mills argues that one event which received a degree of sensationalism in the press was Hollister. ${ }^{97}$ For example, a photo in the July 1947 issue of Life shows "a biker leaning back on his motorcycle, mouth gaping open, beer bottles scattered all around him. ${ }^{98}$ However, despite depicting the biker in such a negative manner, the photograph later turned out to be staged. ${ }^{99}$ The 1964 Monterey incident appears to have been exaggerated by both the media and the authorities. ${ }^{100}$ There was a lack of evidence and all charges were subsequently dropped. ${ }^{101}$ The 1965 motorcycle gang riot in Laconia, New Hampshire was blamed on both the Hell's Angels and Communists, however no Angels were present during this incident. ${ }^{102}$

\footnotetext{
95 Thompson (1970), 138-141.

96 Brake, 64.

${ }^{97}$ Mills, 115.

${ }^{98}$ See Perlman.

99 Ibid.

${ }^{100}$ Rubin, M., 361.

${ }^{101}$ See Syder.

${ }^{102}$ Rubin, M., 362.
} 
The reliability of the Lynch Report has also been questioned. Rubin claims that it contains exaggerations, manipulated statistics, and dubious research. ${ }^{103}$ Thompson sees inaccuracies in the report as well: "A widely quoted section of the Lynch report says these girls are called 'sheep,' but I have never heard an Angel use that word. It sounds like the creation of some police inspector with intensely rural memories." 104 Thompson also argues that the Clovis 'rape' was false, containing a "thundering disparity between accusation and reality," because it was found out that the 'rape victim' was not innocent and had instead encouraged the actions of the bikers. ${ }^{105}$ Thompson similarly sees the rape stories in the press as being largely exaggerated and sensationalized, which he defines as "rape mania." 106 This, again, raises the argument that these press and media stories sought to exploit the biker subjects, not dissimilar to the biker films themselves.

However, one incident involving bikers was not exaggerated by the mass media, and the evidence was captured on film. ${ }^{107}$ As is well known, some members of the Hell's Angels fatally attacked a spectator who brandished a gun during a Rolling Stones concert at Altamont in 1969. In this instance, the Hell's Angels at Altamont became violent "police, judge and executioners." 108 Nate Hendley argues that due to "the combination of booze, power, and an overflow crowd estimated at half-a-million, the Angels went berserk. Bikers with sawed off pool cues mercilessly tore into the crowd, beating people at will." ${ }^{\prime 109}$ Morton argues that this incident confirmed that the Hell's Angels were really as dangerous as everyone thought they were and as press reports had described them, and were not just mere exploited subjects of the mainstream media. ${ }^{110}$

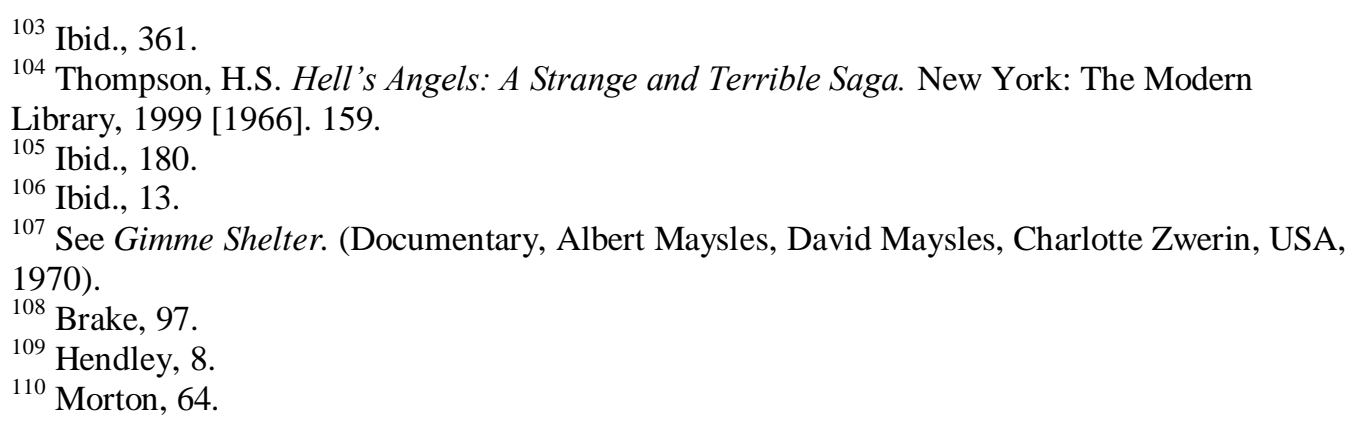


The image of the outlaw motorcycle gangs created by the news media soon attracted the interest of certain filmmakers such as AIP chairman Samuel Z. Arkoff and Roger Corman, an AIP house director at the time. ${ }^{111}$ Arkoff showed an article in the January 1966 issue of Life magazine about the funeral of 'Mother' Miles to Corman and it soon spawned The Wild Angels. ${ }^{112}$ Rubin argues that a major part of the appeal of the biker film is its display of the notorious biker lifestyle, which was both "fascinatingly appalling and vicariously appealing." 113 The negative press stories and their content can also be identified in some of the sensational and spectacular action-set pieces in the biker films. As Syder asserts, "[t]he topicality of the films is evident in the manner in which many of the biker exploits detailed in the press coverage also show up in the movies as well." ${ }^{114}$ Scenes involving fights, rapes, driving montages and other forms of anti-social behaviour are examples of this. Syder maintains that these films were inspired by the press stories of the time: "the fact that the biker movie cycle began in earnest when it did...can be attributed almost entirely to the flurry of media interest in the Hell's Angels at the time." 115 Similarly, Perlman argues that these movies drew on the biker gang's notorious image in the media and also "participated in the construction of the image of the loutish cultural rebel - the social predator roaming about on his motorcycle." 116 In Bill Osgerby's discussion on The Wild Angels, he argues that the film "[fed] on the shrill moral panic that had come to surround the Hell's Angels by 1966" and consequently "turns the bikers into grotesque bogeymen who jar the audience's sensibilities and sneer at their dreary conventions."117 Some later biker films (and press stories) are construed as presenting their biker gangs as a "tribe of killer-hippies," as well as making them "increasingly abstract figures of evil." "118 These darker representations symbolically occurred in the wake and fallout of the Altamont incident, when the biker gang image in the press was arguably at its most negative.

\footnotetext{
${ }^{111}$ See Syder.

${ }^{112}$ Rubin, M., 362.

113 Ibid., 366.

114 See Syder.

115 Ibid.

116 See Perlman.

117 Osgerby, 102

${ }^{118}$ Rubin, M., 374; 376.
} 
The titles of many biker films seem intentionally lurid, and were probably part of an exploitation marketing strategy. This can be linked with the view that the press coverage on real life biker gangs had exploitation qualities. Some biker films, for example, specifically address real life gangs, especially the Hell's Angels. This is evident in the titles of some biker films, such as Hell's Angels on Wheels and Hell's Angels '69. Other biker films allude to the gang through the use of the name 'Angels' in film titles such as The Wild Angels, Devil's Angels, Angels from Hell, Angels Hard as They Come, Angels Die Hard, 'Nam's Angels, Naked Angels (1969), Angel Unchained and Run Angel Run! The latter two films also notably contain biker protagonists named Angel. The word "Hell" also appears in the titles of some biker films, even though they may not necessarily address the Hell's Angels directly, such as Hell's Belles, Hell's Chosen Few and Hell's Bloody Devils. The biker film J.C., meanwhile, was also known as Iron Horsemen in some countries - Iron Horsemen was the name of a real life biker gang. Additionally, the film poster for Hell's Chosen Few boasts the film as being "A shocking new picture filmed in the streets where it actually happened with the real Devil's Henchman, Coffin Cheaters, East L.A. Riders, Tikis, Vikings, Hell's Chosen Few, Rebels, Monks, The Road Rebels, and allied motorcycle gangs, screaming cycles and wild women." 119

While the links between real gangs and biker films have an exploitative element, they also provide the films with a veneer of authenticity. Andrew Syder argues that biker films were appealing at the time, because audience members might not have otherwise seen a real biker gang in the flesh. ${ }^{120}$ Some biker films employed real life biker gang members as actors and advisors. ${ }^{121}$ In Hell's Angels on Wheels, for example, two significant real life Hell's Angels figures, Sonny Barger and Terry the Tramp, have credited appearances in the film. Barger and other members of the Oakland Hell's Angels also feature prominently in Hell's Angels '69, starring as themselves. The Wild Angels similarly features real Hell's Angels - in this instance, members from the

\footnotetext{
119 See Appendix, Fig. 1.

${ }^{120}$ See Syder.

${ }^{121}$ Rubin, M., 356.
} 
Venice chapter. Hell's Bloody Devils also contains a real gang featuring as biker characters. In this instance, it is the Hessians from California, who the film credits as 'Wild Cycle Riders.' Similarly, some of the biker characters in Angel Unchained are played by the real life Dirty Dozen motorcycle club from Arizona.

The biker film also established the themes of the sacking of the American small town and gang-rape. ${ }^{122}$ The town-sacking theme, for example, formed the basis of The Wild One, a film that was inspired by the Hollister riot. ${ }^{123}$ This theme also appears in some 1960s biker films, such as The Savage Seven and Angels Hard as They Come. In The Savage Seven, the town-sacking theme is central to the narrative, which shows its biker characters as rural community invaders after they arrive in a Native American desert town and become self-appointed leaders. In Angels Hard as They Come, the biker gang enters a ghost town that has been re-populated by a group of hippies, and they proceed to take it over by force. The other major biker gang theme documented in the press is rape, or gang rape. This topic also features prominently in the biker film. Rubin maintains that the issue of rape "is a central ingredient of the Hell's Angels mystique and an important contributor to the exploitation appeal of the biker film," and was thus "eagerly recreated in biker movies." ${ }^{124}$ Films in which this theme arguably receives its strongest treatment are The Wild Angels, Devil's Angels, The Cycle Savages, and The Born Losers. This argument will be examined further in the next chapter, which will deal with the biker film in terms of narrative in detail.

There are some biker characters, however, who have been ambiguously represented in the films and are not always fearful figures of evil and hate. Syder argues that there is some uncertainty surrounding the representation of biker gangs in these films: "the depiction of most outlaw bikers falls somewhere between lovable rogue and demented storm trooper." 125 The Wild One and the publication of Cyclists' Raid have contributed to this ambiguity. The Wild One,

\footnotetext{
${ }^{122}$ Ibid., 359-360.

${ }^{123}$ Librett, 183; Mills, 115.

${ }^{124}$ Rubin, M., 366.

${ }^{125}$ See Syder.
} 
for example, "effectively orchestrates a series of unexpected equivalences and role reversals to complicate the central conflict between rebels and straights." "126 Rubin contends that this "moral cloudiness" features significantly in several other 1960s biker films, but with a greater "nihilistic inflection." ${ }^{127}$ In some biker films, such as The Savage Seven, Angels from Hell, The Mini-Skirt Mob, Angel Unchained and J.C., the biker protagonists have been represented more positively than a typical biker representation. This suggests that the biker film contained a confusing mix of signs.

\section{Biker-Hippie Alliance}

The odd juxtaposition of clothing and jewellery in some biker films is interesting because it seems to parallel a real life alliance made between the Hell's Angels and members of the hippie counterculture, which contained an assortment of different and conflicting signs. The onscreen representation of this alliance is another example of the surface authenticity of biker films. Despite being described by Rubin as an "unlikely alliance," 128 and "one of the oddest and most contradictory cultural phenomena" in the era following the Second World War, ${ }^{129}$ these two subcultures shared some views. Rubin focuses on this alliance because he sees this relationship between the bikers and the postwar marginal youth subcultures as being formed through a mutual feeling of nonconformity, rebelliousness and dissent towards American politics and society, and drug use. ${ }^{130}$ However, Osgerby similarly sees the Hell's Angels as being a "symbolic expression of non-conformity," but by taking "the aesthetics of liminal dissent to new extremes — with long hair, Nazi motifs, greasy Levis, and customized motorcycles." ${ }^{131}$ Middle-class countercultural intellectuals also began to relate to and romanticize about the Hell's Angels in terms of recognizing their role as a similar alienated group in revolt. ${ }^{132}$

\footnotetext{
${ }^{126}$ Rubin, M., 360.

${ }^{127}$ Ibid.

${ }^{128}$ Ibid., 373.

${ }^{129}$ Ibid., 356.

${ }^{130}$ Ibid., 373.

131 Osgerby, 101.

${ }^{132}$ Wolfe, 152-153.
} 
Both of these cultural groups were situated outside the realm of mainstream society and shared a similar sense of being "cultural outlaws." 133 Critics argue that these factors contributed to the forming of this alliance. In other words, hippies found the Hell's Angels appealing because they also had "long hair and enjoyed drugs, motorcycles, rock 'n' roll, the bikers were accepted by hippies as rowdy brothers-in-arms." 134 With this in mind, Rubin sees the origins of this commonality as being traced back to the Beat subculture that appeared in American society prior to the emergence of a broader counterculture in the 1960s. "[T] he beats' grooming habits, roving lifestyle, marginal economic position, and flirtations with drugs and criminality corresponded broadly with biker traits." ${ }^{\prime 35}$ Similarly, Mills recognizes parallels between the biker trend and the Beats and their literary works because the Hell's Angels and other motorcycle clubs had a "mutual love of mobility," and also "set out in 1947 to remap the same highways and back roads that Kerouac called the 'vast backyard' of America."136 The affinities between the Beats and the biker gangs are significant because the Beats are a key factor in the development of the youth counterculture in the 1960s. ${ }^{137}$ For example, Ross Coulthart and Duncan $\mathrm{McNab}$ argue that members of the Beat generation "segued smoothly" into the 1960s youth counterculture. ${ }^{138}$

Tom Wolfe's 1968 book The Electric Kool-Aid Acid Test is a significant text to consider in terms of the forming of the biker-hippie alliance in American social history. Wolfe's book examines the alliance formed between the Merry Pranksters and the Hell's Angels. He recounts a 1965 incident in which Ken Kesey and the Pranksters invited some Hell's Angels to Kesey's house in La Honda that resulted in the Angels becoming intoxicated from the Pranksters' LSD. Wolfe has described this meeting as "wonderful and marvelous, an unholy alliance." 139 This was despite the fact that this particular "cultural clash between

\footnotetext{
${ }^{133}$ Issitt, M. Hippies: A Guide to an American Subculture. Santa Barbara: ABC-CLIO, 2010. 12.

${ }^{134}$ Hendley, 8.

${ }^{135}$ Rubin, M., 359.

${ }^{136}$ Mills, 115 - quoting Kerouac, J. On the Road. New York: Penguin, 1976 [1957]. 16.

${ }^{137}$ Monaco, P. The History of American Cinema: The Sixties 1960-1969. New York and Detroit: Charles Scribner's Sons, 2001. 264.

${ }^{138}$ Coulthart, R. and McNab, D. Above the Law: How Outlaw Motorcycle Gangs Established the World's Biggest Criminal Empire. Crows Nest, NSW: Allen \& Unwin, 2010. 25.

${ }^{139}$ Wolfe, 161.
} 
vanguard flower children and atavistic motorcycle thugs had the all makings of a massacre." ${ }^{140}$ Instead it was, in Wolfe's view, a "perfect combination...They were friendly toward them, maybe friendlier than anybody had ever been in their lives, but they weren't craven about it, and they took no shit." ${ }^{, 141}$ Biker film critics also argue that members of the youth counterculture revered the biker gang, in some respects. Osgerby, for one, argues that many countercultural figures "revered the Hell's Angel as a romantic "Noble Savage," fondly imagining the outlaw biker as a personification of raw, spiritual freedom."142 Perlman notes that Allen Ginsberg even wrote two poems about the Hell's Angels. ${ }^{143}$ The gang was fascinated by Ginsberg and saw him as "the greatest straightest unstraight guy they ever met," even though "[he] was a lot of things the Angels hated, a Jew, an intellectual, a New Yorker." ${ }^{\text {"144 }}$ Following the alliance formed between the Hell's Angels and countercultural figures such as Kesey and Ginsberg, the bikers soon became accepted figures in various hippie enclaves. $^{145}$

The Hell's Angels, for example, became reputable figures on the HaightAshbury scene in San Francisco during this period and thus became "unlikely allies" to the residing counterculture there. ${ }^{146}$ Perlman argues that the Hell's Angels were seen as the "holy primitives" of Haight-Ashbury. ${ }^{147}$ Other writers have argued that the Hell's Angels' popularity among Haight-Ashbury hippies was due mainly to their ability to supply drugs. ${ }^{148}$ Rubin maintains that the visiting Hell's Angels became regular fixtures in Haight-Ashbury, and that they subsequently acted as an "unofficial police force at various hippie functions.",149 Due to this alliance, the biker gangs garnered "alternate reputations as cultural

\footnotetext{
${ }^{140}$ Rubin, M., 355.

${ }^{141}$ Wolfe, 158.

142 Osgerby, 102.

143 See Perlman.

${ }^{144}$ Wolfe, 156.

${ }^{145}$ Rubin, M., 355.

${ }^{146}$ Tendler, S. and May, D. The Brotherhood of Eternal Love - From Flower Power to Hippie Mafia: The Story of the LSD Counterculture. London: Cyan Books, 2007. 60.

147 See Perlman.

148 Tendler and May, 60; Gair, C. The American Counterculture. Edinburgh: Edinburgh University Press, 2007. 176.

${ }^{149}$ Rubin, M., 355; for more information on the Hell's Angels' presence in Haight-Ashbury, see Perry, C. The Haight-Ashbury: A History. New York: Wenner Books, 2005.
} 
predators and as counter-cultural heroes." ${ }^{150}$ The same view of the cultural relationship also appeared in the 1965 Lynch Report, which "[served] up a flagrant confusion of right and left signifiers, careening from storm trooper to stereotypical hipster/hippie." 151 These examples further draw attention to the biker gang as representing an odd mixture of signifiers.

The same cultural alliance can be identified in the biker films. There are numerous examples of where both motorcycle and countercultural signs converge in these films. That is, the films and their characters also represent a range of different subcultures. In turn, this suggests that their ideological positions often fluctuate. Even though biker film critics have identified this alliance in the real life context, their proposals seem incomplete and could be explored further by detailing where and how this alliance appears in the biker films; this section will endeavour to do this below. Rubin claims that the biker film is marked by "cultural confusion," in which "representations of biker gangs sent out a riot of clashing signifiers and crossed signals indicative of generational confusion, conflicting cultural styles, and irreconcilable political positions." ${ }^{\prime 152}$ Furthermore, he argues that bikers embody traits of actual bikers and hippies simultaneously. As a result, some biker films contain an uneasy mix of violence and psychedelia, and "play up the resonant clash of swastikas and love beads, tattoos and body paint, gang-rapes and free love, beer-chugging and pot-smoking." 153 Peter Fonda's appearance in The Wild Angels is an example of this, as is his ideological and cultural stance within the film. Fonda's "slender frame, tinted glasses, [and] mop-top haircut" appears to resemble the counterculture more than the outlaw biker. Heavenly Blues' fluid ideological position is made manifest at the funeral of his colleague. He declares, "We want to be free," freedom being both a significant countercultural and biker ideal. He also presides over a brawl and a gang rape at the funeral. Perhaps the most prominent example of a biker protagonist also belonging to the hippie counterculture is the titular character in J.C., who has hippie traits such as long hair, a beard, and a bandana. J.C. preaches the ideals of the counterculture,

\footnotetext{
${ }^{150}$ See Perlman.

${ }^{151}$ Rubin, M., 373.

152 Ibid.

${ }^{153}$ Ibid.
} 
especially in their uprising against "the man." J.C. does not necessarily fit in directly with the protagonists from other biker films, because he does not commit rape and does not fight anyone except characters such as townspeople and authority figures such as the police. Keeg in The Cycle Savages also has several counterculture characteristics, despite being depicted as more violent than biker protagonists such as Heavenly Blues and J.C. In another example, the reformed biker Angel in Angel Unchained leaves his old biker lifestyle behind and ends up working and living on a hippie commune in the desert. He learns to love and live from the land, albeit for a short time before the local townspeople begin troubling him and the commune. In this example, Angel undertakes a transformation from biker to hippie as the narrative develops.

The biker-hippie alliance in the biker film is often represented in the party sequence, or what Rubin calls the Biker Love-In. ${ }^{154}$ This type of scene features many countercultural elements, including "a blend of nudity, casual sex, rock music, pot-smoking, and (when indoors) psychedelic decor." ${ }^{\text {155 }}$ Biker films containing this type of scene include Hell's Angels on Wheels, C.C. and Company, and The Savage Seven. In terms of aural style, the soundtrack of these films is another example of a cultural hybrid. Some biker film soundtracks include music from bands or artists that allude to the counterculture in terms of both their personality and their music and lyrics, featuring "acid-style rock by groups like Cream, Iron Butterfly, and such lesser lights as the Peanut Butter Conspiracy." ${ }^{156}$ Biker films that contain this sort of music include The Savage Seven, Wild Wheels and Angels Hard as They Come. We will also discuss the party scenes further in the next chapter on biker film narratives.

Both the biker film critics and other writers have written about problems within this cultural alliance in social history. This is important because there are also instances in the biker film when the biker gang comes into violent conflict with members of the counterculture. Christopher Gair argues that the inability of the counterculture to connect with bikers across class barriers was one reason for

\footnotetext{
${ }^{154}$ Ibid., 374.

155 Ibid.

156 Ibid.
} 
the hostilities between these groups. ${ }^{157}$ This can be linked to Rubin and Osgerby's claims that this real-life alliance was fragile at times and there were a number of incidents where these two cultures violently clashed. ${ }^{158}$ Many biker gangs, including the Hell's Angels, were supporters of the Vietnam War, and this was a point of friction. Osgerby points out that "the Hell's Angels held the Civil Rights movement in contempt and brutally attacked antiwar activists."159 In one 1965 incident, Sonny Barger and a group of his Oakland Angels attacked an anti-war march, which was the first major confrontation between the bikers and the hippies, and some efforts to reconcile the interests of both the workingclass bikers and the middle-class students and activists proved unsuccessful thereafter. ${ }^{160}$ Rubin contends that this episode was important because "the alliance's underlying contradictions broke through the surface." ${ }^{161}$ The relationship was broken fundamentally by Altamont in December 1969. In Gimme Shelter, a documentary about the concert, a gang member is seen punching the singer from Jefferson Airplane. Sonny Barger is also heard discussing the murder and defending the bikers' actions.

These alliance breakdowns can also be found in the biker film, which further emphasises the links between the films, the real life incidents and press reports. Following Altamont, biker films began representing their characters in a darker tone: "for exploitation filmmakers the [Altamont] outrage was actually a gift. Their murderous reputation confirmed, outlaw bikers featured in a further spurt of exploitation shockers," in films such as Satan's Sadists, Angels Die Hard, Hell's Bloody Devils, Bury Me an Angel, The Hard Ride (1971), and The Wild Rebels. ${ }^{162}$ Conflict between bikers and hippies also appeared in the films. Osgerby argues that in Angel Unchained and Angels Hard as They Come "the hippy commune [replaced] the small-town community as the target of biker carnage." ${ }^{163}$ In Angels Hard as They Come gang member Long John's hippie love-interest is killed by a rival gang who disrupt the hippie community

\footnotetext{
${ }^{157}$ Gair, 176.

${ }^{158}$ Rubin, M., 356; Osgerby, 102.

${ }^{159}$ Osgerby, 102.

${ }^{160}$ Thompson - quoted in Gair, 127; see also Hendley, 7.

${ }^{161}$ Rubin, M., 356.

162 Osgerby, 107.

${ }^{163}$ Ibid.
} 
established in an abandoned town, while in Angel Unchained some bikers clash with a group of hippies after they are originally brought in to act as their security against the onslaught of the antagonistic locals. Another example of the biker-hippie hostility occurs in Angels from Hell, when Bull and the hippie girl exchange insignia before he rapes and kills her.

\section{New Hollywood}

The biker film contains a mix of cultural traces which are sometimes contradictory and bewildering. There is also some uncertainty about how we can position the biker film in terms of its production and exhibition contexts. To explore this point, it is important to examine the various contexts in which films of this period were made. This section of the chapter will thus provide an overview of the changes in both audiences and exhibition in the late-1960s and early-1970s. Peter Lev argues that the film audience during this period "shrank and fragmented, and the verities of the old studio system fell apart." ${ }^{\text {164 }}$ Cinema audiences in the post-war period decreased from 90 million in 1946 to 20 million in $1970 .{ }^{165}$ There appears to be a number of societal and industrial factors for this decline. One of these factors would be the migration to the suburbs made by many people during this period, which moved people away from the city, where many of the cinemas and theatres were situated. ${ }^{166}$ This largely accounted for the increase in attendance in the drive-in circuit, as many drive-ins were situated on the outskirts of towns and cities and closer to the suburban enclaves than the hardtop theatres. The decline in cinema audience was also influenced by the impact of television. ${ }^{167}$ Thomas Doherty claims that the rise in television destroyed the "universality" of the cinema audience, when more people stayed at home. ${ }^{168}$ However, as King contends, "the rise in television was only one aspect of a wider process of social change that undermined and shifted the social and cultural position of cinema." 169

\footnotetext{
${ }^{164}$ Lev, P. American Films of the 70s: Conflicting Visions. Austin: University of Texas Press, 2000. xvi.

${ }^{165}$ Monaco, 40.

${ }^{166}$ Rubin, M., 369.

${ }^{167}$ Mills, 118.

${ }^{168}$ Doherty, T. Teenagers \& Teenpics: The Juvenilization of American Movies in the 1950s. Boston: Unwin Hyman, 1988. 3.

${ }^{169}$ King, G. New Hollywood Cinema: An Introduction. New York: Columbia University Press, 2002. 24.
} 
As a result, Hollywood in this period was compelled to find new audiences, and this gave new opportunities to filmmakers dealing with exploitation and youth topics and themes at the time. "[V]arious new directions were possible and a number of talents who often offered some alternative to the classic concepts of Hollywood filmmaking gained an opportunity to display their talents and pursue their ideas." 170 The younger audiences in this period were also looking for new films to challenge the mainstream Hollywood pictures that were being produced. Noel King argues that New Hollywood was "an adventurous new cinema" which linked "the traditions of classical Hollywood genre filmmaking with the stylistic innovations of European art cinema. This concept of 'the new' is predicated on a new audience demographic making its aesthetic preferences felt by opting for a new kind of cinema." 171 This was a cinema in which the young generation finally had a voice, in the mainstream realm at least.

These films also connected with the biker film, as they formed a link with the social history of the period. Alexander Horwath maintains that the New Hollywood details "the intensity of the social movements, changes, shocks and crises, which rocked American society in the Sixties and early Seventies." 172 Geoff King makes a similar point but links it to film form as well: "The films of the Hollywood Renaissance have been celebrated for offering some degree of radical political potential, in both content and departures from classical style. This is seen as a reflection of some of the radical currents in American culture in the period." ${ }^{\prime 13}$ The changes and new opportunities they provided helped create the film movement which has come to be known as New Hollywood or the Hollywood Renaissance. ${ }^{174}$ By discussing New Hollywood cinema here, an overarching framework will be established which will allow this discussion to be followed with other arguments concerning the exploitation genre and films

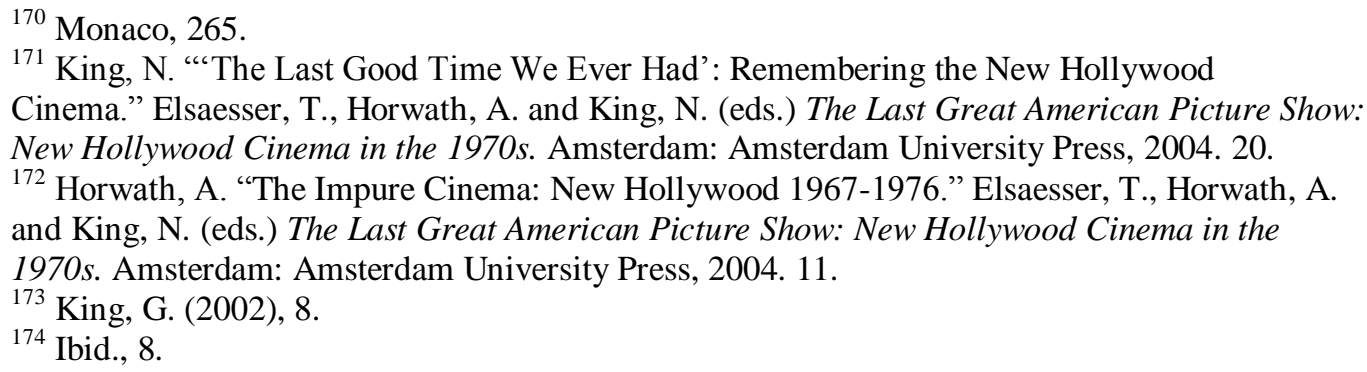


specifically addressing the counterculture and youth audiences. This will be done in order to demonstrate the argument that 1960s and 1970s biker films are difficult to define.

This was a difficult period for the major Hollywood studios, especially in terms of the popularity of low-budget exploitation cinema and films that specifically targeted the youth audience. Hollywood was concerned because this audience lacked size and homogeneity, which were "the very qualities that the entertainment industries demanded." 175 Thomas Schatz argues that because of this, filmmaking in the mid-to-late 1960s was built around

flexibility and experimentation... as filmmakers and producers sought to define that audience and their shared interests...fuelled not only by the political and cultural unrest of the period but also the growing number of independent outfits like AIP willing to go exclusively for the youth market. ${ }^{176}$

Aniko Bodroghkozy claims that in this period some major Hollywood studios began to see this audience as their "economic salvation." 177 Bodroghkozy contends that Hollywood studios wanted to appeal to members of the middleclass baby boom, but this was problematic because this was a period in which "the most vocal edge of that group was engaged with antiestablishment politics that put many of the young in the film industry's potential audience at odds with all mainstream institutions." ${ }^{178}$ Hollywood was therefore realising how profitable and lucrative the youth market for anti-Establishment films could be and began to target them by producing films that had a similar appeal as those released by independent studios and production companies. ${ }^{179}$ As discussed in the previous chapter, this was true of Easy Rider, which was an enormous financial success.

${ }^{175}$ Schatz, T. Old Hollywood/New Hollywood: Ritual, Art, and Industry. Ann Arbour, Mich.: UMI Research Press, 1983. 195.

176 Ibid.

${ }^{177}$ Bodroghkozy, A. "Reel Revolutionaries: An Examination of Hollywood's Cycle of 1960s Youth Rebellion Films.” Cinema Journal. Vol. 41, No. 3. (Spring 2002.) 39.

178 Ibid., 55

${ }^{179}$ Schatz, 197. 
During this period the demographics of movie attendance in America shifted towards an increasingly younger, male audience, ${ }^{180}$ with approximately threequarters of 16-20 year-olds being regular cinema attendees. ${ }^{181}$ The expectations of this audience were also changing. Douglas Gomery argues that many young cinemagoers "were seeking alternative lifestyles, new ways to look at and understand their turbulent world." "182 Films such as Bonnie and Clyde, Easy Rider and Alice's Restaurant (1969) are examples of films that appealed to audiences for this reason. However, Geoff King claims that although many films during this period were targeted at a broad audience, "some were targeted at the growing 'youth' audience [while] others aimed more challenging or explicit material at an 'adult' market." ${ }^{, 183}$ King is suggesting that the audiences for the films of this period are difficult to clearly establish.

The increase in graphic themes of sex and violence also influenced the domination of the youth audience. Stefan Kanfer maintains that the relaxation in censorship was "[a]n important factor in the rise of challenging youth-oriented films." ${ }^{184}$ King argues this point further:

Much more explicit depiction of sex and violence and controversial social issues became possible. This was part of broader social and cultural changes in the post-war decades. But it was also closely linked to changes in the industrial situation of Hollywood, especially in terms of its strategies of audience targeting. ${ }^{185}$

This censorship relaxation occurred because of the collapse of the Production Code, which was revised throughout the 1960s and abandoned in 1968, when it was replaced by a rating system. ${ }^{186}$ With the Production Code breakdown, "[m]uch more explicit depictions of sex and violence and controversial social

\footnotetext{
${ }^{180}$ Monaco, 45.

${ }^{181}$ Krämer, P. The New Hollywood: From Bonnie and Clyde to Star Wars. London and New York: Wallflower, 2005. 7.

${ }^{182}$ Gomery, D. Movie History: A Survey. Belmont, CA: Wadsworth Publishing Company, 1991. 332-333.

${ }^{183}$ King, G. (2002), 30.

${ }^{184}$ Kanfer, S. "The Shock of Freedom in Films." McClure, A.F. (ed.) The Movies: An American Idiom. Rutherford: Fairleigh Dickinson University Press, 1971 [1967]. 333; also quoted in Krämer (2005), 38.

${ }^{185}$ King, G. (2002), 8.

${ }^{186}$ Ibid., 31.
} 
issues became possible." ${ }^{187}$ Films such as Bonnie and Clyde and The Wild Bunch (1969), for example, contained more graphic depictions of violence than had previously been seen in films. Similarly, films such as The Graduate (1967) and Midnight Cowboy (1969) dealt with sexuality in a more explicit manner than before. These changes also occur in the biker film. Because the themes of violence and sex feature prominently in the biker films, these films can be associated with the cinematic changes in this period - such as the relaxation of censorship codes - thus linking them to the New Hollywood cycle, as well as other exploitation and youth films in the 1960s and early-1970s.

\section{Exploitation Cinema}

Biker film critics have classified the biker film as exploitation cinema, which is also fluid and difficult to define clearly. Thomas Elsaesser argues that the exploitation film was also a hybrid in some respects: "its mixture of grindhouse, sweatshop and the various archipelagos of creative freedom, experiment and even exuberance." ${ }^{\prime 188}$ Doherty proposes that exploitation cinema typically has three elements: "controversial, bizarre, or timely subject matter amenable to wild promotion...a substandard budget...[and] a teenage audience." 189 These factors correspond with Monaco's view of American International Pictures' approach to production, which was to "Spend no money...Play up the basest, most sensationalized angle [and] Exaggerate wildly in the advertising." 190 John Belton argues that exploitation cinema consists of risqué themes such as violence, sex, drug use, and "wilfully disobedient youth," 191 while Ethan Mordden contends that "exploitation purports to treat a theme of the day with some abandon." ${ }^{, 192}$ In terms of the biker film, Rubin similarly claims that it is through factors such as "highly context-dependent and often judgemental criteria regarding content, quality, production conditions, and...the exhibition situation" that the biker film can be more regarded as an exploitation film.

\footnotetext{
${ }^{187}$ Ibid., 8.

${ }^{188}$ Elsaesser, T. "American Auteur Cinema: The Last - or First - Great Picture Show." Elsaesser, T., Horwath, A. and King, N. (eds.) The Last Great American Picture Show: New Hollywood Cinema in the 1970s. Amsterdam: Amsterdam University Press, 2004. 51.

${ }^{189}$ Doherty, 8.

190 Monaco, 28.

${ }^{191}$ Belton, J. American Cinema/American Culture. New York: McGraw-Hill, 2009. 349.

192 Mordden, E. Medium Cool: The Movies of the 1960s. New York: Knopf, 1990. 213; also quoted in Lev, 3.
} 
These include unsavoury subject matter focusing on the biker gang's lifestyle of physical and sexual violence, low-budget and independent production, the drive-in context, and critical opprobrium. ${ }^{193}$

There are also strong links between exploitation cinema and the press coverage of biker gangs in the post-war period. One factor of exploitation cinema is the connection of their narratives to real life situations and events. Doherty argues that the exploitation film "drew on the public curiosity and free publicity surrounding a current event. They were 'exploitation naturals' because the 'real' occurrences they took their inspiration from had already aroused public curiosity." ${ }^{194}$ In terms of both the exploitation film and the biker film, it was young anti-authoritarian males that were the focus point of public curiosity - in the juvenile delinquents and biker gang members respectively - where both groups were seen to be a serious threat to the social order. ${ }^{195}$ The focus on teenagers in both the public discourse and in newspaper articles made them appropriate subjects of exploitation films, ${ }^{196}$ much the same way as bikers had done for the biker films. While the public anxiety regarding teenagers was largely situated in the 1950s, the same public curiosity and outcry links the exploitation film with the biker film, which arguably is one reason why biker films have been described as exploitation films by the biker film critics. Additionally, in the press stories and newspaper articles, the biker subjects and their lurid lifestyles are similarly 'exploited' for the mass market. The biker films exploit their biker characters, and subjects, in the same way.

Mills argues that some exploitation filmmakers saw themselves, and are regarded as, marginalized figures in Hollywood and made films that were largely a rebellious reaction to mainstream cinematic conventions, and were therefore "vehicles" for exploitation filmmakers to channel their own rebellion and marginality onto the screen. ${ }^{197}$ Kramer also claims that "the generations of filmmakers who rose to dominance in Hollywood in the late 1960s...were at the

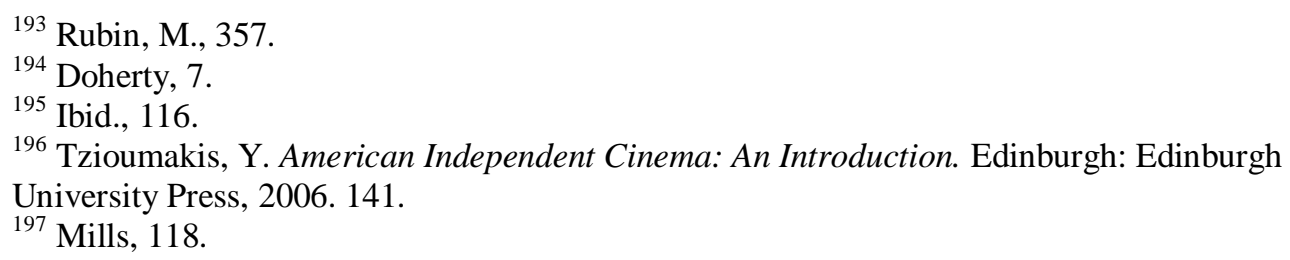


forefront of certain changes in attitude, beliefs and values in society, acting as a kind of vanguard."198 Maitland McDonagh contends that exploitation filmmakers "were steeped in the rebellious mores of the 1960s, which celebrated sex, drugs, rock music, pop art, high camp, low culture, épater le bourgeois pranks and wholesale rejection of venerable social institutions."199 This gave exploitation filmmakers the creative freedom to channel their own marginal views and perspectives on the state of society and cinema at the time. Some biker filmmakers can be seen as marginal figures as well, by identifying their expression of rebellion through tales of reactionary, violent and nonconformist motorcycle gangs. Corman, for example, "became more radical and anti-Establishment" in his political views during this period by offering a more 'liberated' perspective for his LSD drug film The Trip (1967) and making a youth protest film Gas! -Or- It Became Necessary to Destroy the World in Order to Save It (1970). ${ }^{200}$

The best known of these filmmakers is, of course, Roger Corman. Corman was a director for AIP - which produced a number of biker films - and he also directed The Wild Angels. He is regarded as being a seminal figure in the history of the exploitation genre and, as a result, New Hollywood. In the exploitation genre he produced and directed numerous low-budget films throughout the 1950s and 1960s. Corman's connection with the New Hollywood comes from his role as the financer and mentor of many young directors (the movie 'brats') who arose in cinema in the late-1960s and early-1970s, such as Francis Ford Coppola, Martin Scorsese, John Milius and Steven Spielberg. Corman thus becomes an important link between these three areas. His associations with AIP confirm his significance to the biker film, because biker film critics regard AIP as the most important and prominent studio in relation to the biker film. Rubin claims that AIP "produced and/or distributed many more biker films than any other single company," and was also, in terms of exploitation cinema, "the first

\footnotetext{
${ }^{198}$ Kramer, P. "Post-classical Hollywood.” Hill, J. and Church Gibson, P. (eds.) American Cinema and Hollywood: Critical Approaches. Oxford: Oxford University Press, 2000. 75. ${ }^{199}$ McDonagh, M. "The Exploitation Generation. Or: How Marginal Movies Came in from the Cold." Elsaesser, T., Horwath, A. and King, N. (eds.) The Last Great American Picture Show: New Hollywood Cinema in the 1970s. Amsterdam: Amsterdam University Press, 2004. 110. ${ }^{200}$ Corman, R. with Jerome, J. How I Made a Hundred Movies in Hollywood and Never Lost a Dime. New York: Random House, 1990. 231; also quoted in Osgerby, 105.
} 
company to cater successfully to the postwar youth market." ${ }^{201}$ Osgerby claims that AIP produced about a dozen biker films, including the pre-1960s biker cycle film Motorcycle Gang in $1957 .^{202}$ These include The Wild Angels, as well as Devil's Angels, The Born Losers, The Glory Stompers, The Savage Seven, The Mini-Skirt Mob, Angels from Hell, Hell's Angels '69, Hell's Belles, Angel Unchained, The Hard Ride and Chrome and Hot Leather.

However, in terms of production companies and studios for biker films, AIP was hardly alone. Osgerby argues that William Grefe is a notable figure in this period in regards to the biker film, having written and directed Hell's Chosen Few. ${ }^{203}$ Osgerby also maintains that Titus Moody - who directed Hell's Chosen Few - and K. Gordon Murray - the writer, producer and composer of Savages from Hell - are also important. ${ }^{204}$ Biker film critics argue that there were a number of biker film producers and studios that followed in AIP's footsteps, such as Joe Solomon's Fanfare Films, which went on to produce The Born Losers, Run Angel Run!, Wild Wheels and Nam's Angels. ${ }^{205}$ Rubin also mentions Allied Artists, Sam Katzman and Albert Zugsmith as important producers of biker films. ${ }^{206}$ Many of these filmmakers and studios were also strongly linked to the exploitation cinema prior to the biker film, and thus help to associate, and 'bridge', these two types of films.

However, according to Rubin the biker film does not belong entirely to exploitation cinema. He argues that although factors of exploitation cinema can be recognized and identified in the biker film, these films perhaps do not carry such solid exploitation staples as other low-budget and independent films from the same era. This is because the biker film is seen as "bleeding across the borderline of their exploitation niche." ${ }^{207}$ In other words, the biker films fit in with a number of other film 'types' of the same era that appear similar to each other yet remain distinctive depending on their subject matter. Rubin maintains

\footnotetext{
${ }^{201}$ Rubin, M., 369.

202 Osgerby, 104.

${ }^{203}$ Ibid.

${ }^{204}$ Ibid.

205 See Perlman.

${ }^{206}$ Rubin, M., 369.

${ }^{207}$ Ibid., 357.
} 
that there was "a general blurring-cum-alignment of the lines between exploitation films, youth films, art films and commercial genres during this exceptionally unsettled period of American history."208 These other similar 'types' of film include the revisionist Western, the youth protest film, the Hollywood 'art film', and the countercultural drug film. ${ }^{209}$ Rubin makes a point of separating these different types of film, even though they are all associated with each other in various ways. He links the fluid boundaries in the biker film with the events that were occurring in the wider American film industry in the 1960s, where "filmmaking boundaries were greatly in flux, including those between exploitation movies, the commercial mainstream, and art cinema."210 This consequently makes the 'exploitation film' seems like "a vague and loaded term. $" 211$ Because of the crosscurrents in filmmaking at this time, Rubin maintains that the biker films are contradictory and thus their position with the film industry is problematic: "The form of the biker film was both extended and dissipated by its positioning among the contradictory crosscurrents of the period." ${ }^{212}$ This argument is important because it foreshadows my arguments in chapter four where I propose that the biker film can be placed in a range of generic contexts, and that these are intertwined with gender issues.

\section{Marketing and Exhibition}

Another way in which the biker film can be associated with the exploitation cinema is through their similar marketing and advertising strategies, which was largely "outlandish, mildly controversial, and a little licentious." 213 This type of advertising can be found in the promotional marketing and advertising for biker films, especially through their film posters. The posters include vibrant, stark and lurid images of big bikers, huge motorcycles, half-naked women and a punchy, rebellious tagline, which were considered "provocative" due to their explicit and sensationalist images. ${ }^{214}$ The poster for Devil's Angels is one such example. It contains images of biker gang members and fight sequences merged

\footnotetext{
${ }^{208}$ Ibid., 370.

${ }^{209}$ Ibid., 357.

${ }^{210}$ Ibid.

${ }^{211}$ Ibid., 356.

212 Ibid., 357.

${ }^{213}$ Doherty, 9.

${ }^{214}$ Rubin, M., 357.
} 
with a fire and flame design. The tagline reads "Their God is violence and - like rabid dogs ... Lust is the law they live by." 215 Similarly, the poster for Angels Die Hard features a scantily clad woman wearing a German iron cross, with other various lurid images of the biker lifestyle. The tagline for this film reads "Chopper outlaws! ... Riding their hot throbbing machines to a brutal climax of violence! Their battle cry - "Kill the pigs." ${ }^{216}$ In the poster for Angels Hard as They Come, the two main images are of a woman with her legs apart, sitting behind an image of a biker gang member rearing his motorcycle up in a menacing and threatening manner. The poster's tagline is "Big men with throbbing machines and the girls who take them on. They ripped off his mama ... so he tore chopper city apart. An eye for an eye ... a piece for a piece." ${ }^{217}$ These marketing strategies were ultimately designed to shock, titillate, and entice the viewer to watch these biker films, much like the marketing and content of many other exploitation films in the period.

In terms of the relationship between biker films and exploitation cinema, it is also important to consider the exhibition context of the former. Biker film critics argue that the main site of exhibition for exploitation films produced by studios such as AIP was the drive-in theatre. ${ }^{218}$ This type of exhibition space was part of a somewhat contradictory demographic pattern that occurred in the post-war period. As previously discussed, there was a sharp decline in cinema attendance in postwar America. This occurred at a time when large numbers of people were moving to the suburbs. It also coincided with the expansion of automobile culture, especially among young people. Yet, these trends were accompanied by a significant increase in drive-in theatres. For example, while the number of drive-ins rose by about 3,000 between 1948 and 1954, the number of hardtop cinemas decreased by the same amount. ${ }^{219}$ Rubin argues that there were a number of significant factors to both the convenience and popularity of the

\footnotetext{
215 See Appendix, Fig. 2.

${ }^{216}$ See Appendix, Fig. 3.

${ }^{217}$ See Appendix, Fig. 4; for more examples see Appendix, Figs. 5-8.

${ }^{218}$ See Syder; Rubin, M., 370; see Perlman.

219 Tzioumakis, 141-142.
} 
drive-in circuit, which included a proximity to the suburbs, lower ticket prices and group-orientation. ${ }^{220}$

The composition of the actual audiences for biker films is difficult to ascertain because an empirical study of the necessary historical data is beyond the scope of this project and the resources available to it. Instead, I will propose that it is likely that there were two different but occasionally overlapping audiences for these films. The first was the "drive in/exploitation/blue-collar camp" and the second was the "art-house/counterculture/middle-class camp."221 This hybrid thus makes the biker film something of "a site for the inscription of cultural and generational tensions." 222

\section{Audiences}

Some writers have argued that the audience for drive-in movies was predominantly young. ${ }^{223}$ Victoria O'Donnell argues that the main audience in the drive-ins were teenagers, ${ }^{224}$ which was also AIP's target audience demographic. ${ }^{225}$ However, Rubin contends that the spectators for this type of film exhibition space were more distinguishable from just a generalized youth audience, and can instead be categorized in class terms. He suggests that drivein audiences after 1960 were "more low-income, non-family, male-dominated, and poorly educated, with a particularly sharp increase in blue-collar, pinkcollar and unemployed patrons. ${ }^{226} \mathrm{He}$ also claims that the attendees of the drive-in circuit were a "redneck, white-trash, and blue-collar" audience. ${ }^{227}$ Syder also argues that the scenes of "action, titillation and sensationalism" in exploitative drive-in movies appealed to "an unsophisticated crowd." 228 These arguments made by Rubin and Syder are somewhat problematic. Other research on drive-in audiences can be used to refute, or challenge, Rubin and Syder's

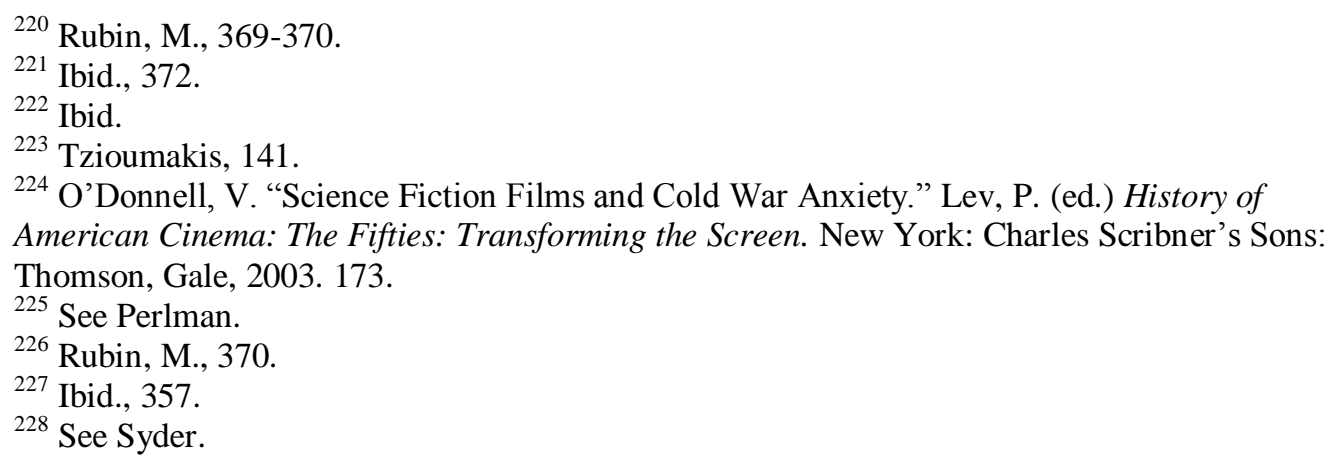


claims. Belton, for example, argues that audiences for drive-ins were broader and more family-oriented: "couples with young children took the kids along with them to the drive-in... Many drive-ins provided playgrounds for children to amuse themselves in until the picture started." ${ }^{, 29}$ Again, this presents problems when trying to define audiences for various films and exhibitions in this period, and questions the validity of some biker film critics' claims.

However, trying to define the 'youth' cinema in this period is also problematic because there are a number of different groups that contribute to this audience, even though the youth audience has been conceived of in largely monolithic terms. ${ }^{230}$ Rubin maintains that there were instead several distinct groups of young people targeted by this cinema, including the pre-boomer, countercultural boomer and conservative boomer. These have overlapping and conflicting interests. ${ }^{231}$ Rubin's claim is supported by Belton's argument regarding the diversity in audiences during this time: "“youth cohorts' are not monolithic" and are instead comprised of many differences such as "urban, suburban, rural; male and female; social and economic class; 'hip' and 'square' liberal and conservative, engaged and detached, pro-war and anti-war, and so on."232 The fluidity of the audience reinforces the view that the cinema of this period is less homogenous and more uneven than is sometimes thought.

Regardless of how we might define the youth audience, there appears to be some difference between what Rubin calls the blue-collar audience at driveins $^{233}$ and a more middle-class and college-educated audience that was at least partly interested in art cinema. ${ }^{234}$ "The art film audience was self-defined as better educated, more sophisticated, and more cosmopolitan in its tastes than the adherents of mainstream feature films." 235 Films such as Easy Rider and Alice's Restaurant appealed to this specific audience arguably because they "are about,

\footnotetext{
${ }^{229}$ Belton, 325-326.

${ }^{230}$ Rubin, M., 373.

${ }^{231}$ Ibid.

${ }^{232}$ Monaco, 264-265.

${ }^{233}$ Rubin, M., 357.

${ }^{234}$ Schatz, 190; Belton, 360; Brake, 93.

${ }^{235}$ Monaco, 44.
} 
and presumably addressed to, middle-class white youths. ${ }^{, 236}$ Drehli Robnik also argues this point: "the early period of New Hollywood...is marked by the film industry's relationship with countercultural values and audience positions."237 This audience was interested in a range of films and filmmaking styles, but was especially interested in films that mirrored their own lifestyles and behaviour, such as campus rebellion and films dealing with alternative lifestyles. ${ }^{238} \mathrm{King}$ claims that the primary source of appeal to the 1960s youth audience was the celebration of the counterculture. ${ }^{239}$ Monaco maintains that "the young, male movie audience for movies appeared to be most interested in stories and characters challenging their own sense of adolescent boredom and their parents' conventional values." ${ }^{240}$ Elsaesser similarly argues that in the 1970s films "reflect stances of dissent typical among minority groups, such as the young or college-educated spectators. ${ }^{241}$ Films that focused on drugs, such as The Trip and Psych-Out (1968), as well as other films dealing with social and political issues during this period, including Medium Cool (1969), The Strawberry Statement (1970), Wild in the Streets (1968) and Zabriskie Point (1970) are examples of films that were popular with this audience due to their antiestablishment and non-conformist content.

Bonnie and Clyde was arguably the first mainstream film in the 1960s to succeed with a young and antiestablishment audience because it contained scenes of sexual frustration and graphic violence. ${ }^{242}$ Bonnie and Clyde also appealed to this audience due to their "cross-country spree [which] captured the spirit and energy of the youth movement and epitomized the revolt against institutional authority that found support among young moviegoers of the mid-

\footnotetext{
${ }^{236}$ Lev, 16.

${ }^{237}$ Robnik, D. “Allegories of Post-Fordism in 1970s New Hollywood: Countercultural Combat Films and Conspiracy Thrillers as Genre Recycling”. Elsaesser, T., Horwath, A. and King, N. (eds.) The Last Great American Picture Show: New Hollywood Cinema in the 1970s. Amsterdam: Amsterdam University Press, 2004. 347.

${ }^{238}$ See Bodroghkozy for more information of these types of films.

${ }^{239}$ King, G. (2002), 17.

240 Monaco, 45.

${ }^{241}$ Elsaesser, T. "The Pathos of Failure: American Films in the 1970s: Notes on the Unmotivated Hero." Elsaesser, T., Horwath, A. and King, N. (eds.) The Last Great American Picture Show: New Hollywood Cinema in the 1970s. Amsterdam: Amsterdam University Press, 2004. 281-282.

${ }^{242}$ Belton, 350.
} 
1960s." ${ }^{243}$ Elsaesser, meanwhile, argues that Bonnie and Clyde deals with a "triple agenda of self-obsessed youth, aestheticised violence, and a distrust or contempt for all forms of established authority." 244 All of these themes parallel the tenets of 1960s youth culture. Other countercultural films in this period also dealt directly with the youth movement's disaffection and alienated confusion, such as in The Graduate. ${ }^{245}$ Belton argues that The Graduate "foregrounds the situation of disaffected youth in ways that appealed to the under-30 market."246 Alice's Restaurant is another film that draws parallels with the youth subcultures of the era, especially in its rejection of military service and the draft. ${ }^{247}$ Similarly, Greetings (1968) also deals with the timely issues of the draft and the antiwar movement. ${ }^{248}$

Another group of films made during this period that arguably capture the antiestablishment feelings of disaffection of the nation's youth were the campus rebellion films. Bodroghkozy argues that during this period "Hollywood found itself trying to sell films that represented campus turmoil, the radicalization of young people, and the violence associated with student rebellion." ${ }^{249}$ Such films include The Activist (1969), Getting Straight (1970), The Strawberry Statement, R.P.M. (1970), Wild in the Streets and Zabriskie Point. These films "express something of the anarchic energy of 1960 s youth culture." ${ }^{, 250}$ As J. Hoberman claims, "Wild in the Streets recasts juvenile delinquency as a political movement" and "offers an intoxicating fantasy of youthful autonomy." 251 This directly corresponded with the middle-class youth audience because these films dealt with issues of college rebellion that were occurring in American society at the time. This also gives the campus rebellion films a degree of social realism. As Bodroghkozy argues, "the cycle of campus revolt films did not circulate during a period of quiescence. Spring 1970 was marked by [Kent State and

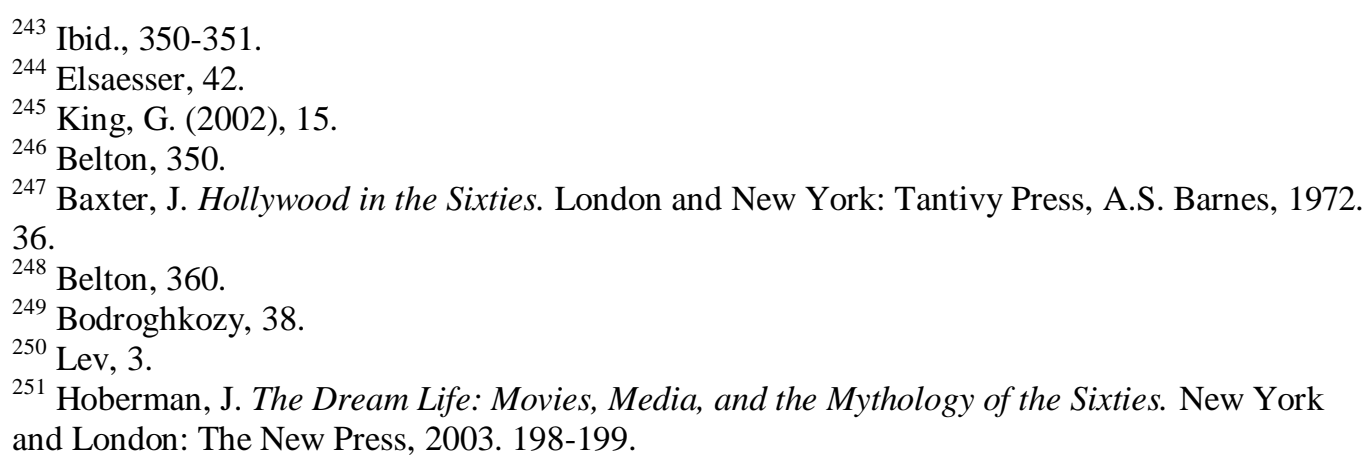


invasion of Cambodia]...A full-scale national student strike crippled and shut down universities throughout the nation, brought hundreds of thousands of students in the streets. ${ }^{, 252}$ In terms of the campus rebellion films, they also exhibited the same kind of discomfort and anxiety that were evident in the real life upheavals on campuses around the country: "Textual markers of 'the real' were not limited to the use of nonactors connected to the youth movement or to the use of documentary footage of protest events...Each of the films contained scenes of campus uprisings structured according to codes and conventions of cinema vérité." 253 Again, because these films dealt with real issues of campus rebellion, they were arguably targeted mainly to, and received by, the very kind of college-educated groups that were being depicted onscreen. This has some affinities with the way biker films of the same period were received by audiences.

Interestingly, Rubin is the only biker film critic who discusses the biker film's association with New Hollywood in detail, while the others largely ignore this issue. Rubin argues that the biker film "shares certain general aspects of characterization, theme and structure with some of the foreign-influenced, antiheroic, anti-establishment 'New Hollywood' films of that era." ${ }^{254}$ For example, the protagonists in the New Hollywood and in biker films are both similarly "social misfits, deviates, or outlaws." 255 Both Clyde Barrow and Heavenly Blues can be linked through their roles as anti-establishment "outlaws" and antiauthoritarian social rebels. As King suggests, one major feature of a large number of New Hollywood films is the "foregrounding of youthful alienation and/or rebellion." ${ }^{256}$ While Bonnie and Clyde and Benjamin Braddock - the protagonist of The Graduate - may have brought these themes to prominence in New Hollywood, so do many protagonists in biker films.

The youth audience, exploitation cinema and New Hollywood come together in a film like Easy Rider. This is because the story focuses on two bikers who are

\footnotetext{
252 Bodroghkozy, 41.

253 Ibid., 43.

${ }^{254}$ Rubin, M., 357.

255 Ibid., 372.

${ }^{256}$ King, G. (2002), 15.
} 
recognizable countercultural figures, but are a stronger example of this than the characters in biker films. Easy Rider can be "interpreted as a synthesis of biker/exploitation and New Hollywood/art film ingredients, absorbing biker mythology into a countercultural context, much as Ken Kesey and his Merry Pranksters had done four years before. ${ }^{, 257}$ It has been regarded as an exploitation film, ${ }^{258}$ and also something of an underground film, due to its employment of "stylistic practices found in the nonnarrative, experimental cinema.",259

By linking the biker film with New Hollywood cinema, the biker film can thus also be associated with 1950s and 1960s European art cinema, as these latter films influenced the films of New Hollywood, including Bonnie and Clyde, The Graduate and Easy Rider. ${ }^{260}$ These European films are significant because they "[catered] to audiences primarily in urban areas and college towns," prior to the release of some 1960 s films that directly addressed this audience. ${ }^{261}$ On a narrative level, the biker films can be seen to be linked to the European films via structure and characterisation. In terms of narrative structure, the European films are seen as having "a looser, more tenuous linkage of narrative events, for which absolute closure was not necessary." ${ }^{262}$ We will explore this in the next chapter. A similar association can be made with the characters of these two types of films: "Whereas characters in the Classical Hollywood cinema had to be well rounded, operating with clear-cut traits and characteristics, the European influence allowed for the possibility of confused characters, without clear goals." ${ }^{263}$ The following chapter will claim that although there are some cases in which some protagonists in biker films seem goal-oriented, motivated and driven, many characters remain alienated, goalless and underdeveloped. As a result, the narrative structures of biker films are relatively loose.

\footnotetext{
${ }^{257}$ Rubin, M., 372.

${ }^{258}$ Belton, 353; Lev, 3.

${ }^{259}$ Belton, 353.

${ }^{260}$ Rubin, M., 370-372.

${ }^{261}$ Monaco, 44.

${ }^{262}$ Gomery, 313; also quoted in Rubin, M., 371.

${ }^{263}$ Ibid., 313-314; also quoted in Rubin, M., 371.
} 


\section{Conclusion}

This chapter has discussed the biker film from a number of different perspectives. As a result, it is clear that the biker film is something of a critical, industrial and cultural hybrid in the broader context of New Hollywood cinema. It is now appropriate to analyse the textual dimensions of the biker film in order to establish whether these films possess the narrative, stylistic, and thematic features of other American films made during this period. 


\section{Introduction}

The narratives of 1960s and 1970s biker films appear to be a mixture of both classical and post-classical narration. On the one hand, these films contain characters that are motivated and goal-oriented and thus help progress the story structures forward through causally related events. On the other hand, these films also contain many scenes of spectacle, which consequently fragments the narrative structure of these films. This suggests that these films belong to a postclassical narrative model. Closer analysis suggests that the biker film tends to be more post-classical than classical. For example, there is arguably much more emphasis on the scenes of spectacle in these films than there is on character motivation and goal-orientation. This is because every biker film analysed in this study contains scenes that can be regarded as spectacular: they contain numerous sequences involving violence, movement, and celebrations.

This chapter will start by considering examples of where classical conventions appear in these films by emphasising the specific traits of character motivation, romantic lines of action, and scene construction. David Bordwell's work on classical narration will inform this discussion. ${ }^{264}$ We will then focus on the ways in which the biker film narrative can be regarded as post-classical. This will be identified through the elements and traits of unmotivated characters, the 'interruptions' or 'punctuations' of spectacle in the narrative, and the functioning of this spectacle as 'attractions' in Tom Gunning's sense of the term. ${ }^{265}$ These findings are significant because the biker film narrative has not been comprehensively analysed in this way. Therefore, one of the purposes of this chapter is to extend what the critics have said about the narratives of these films by placing their arguments within a wider theoretical context. For example,

${ }^{264}$ See Bordwell, D. Narration in the Fiction Film. Madison: University of Wisconsin Press, 1985; Bordwell, D. Staiger, J. and Thompson, K. The Classical Hollywood Cinema: Film Style \& Mode of Production to 1960. New York: Columbia University Press, 1985.

${ }^{265}$ See Gunning, T. "An Aesthetic of Astonishment: Early Film and the (In)Credulous Spectator.” Williams, L. (ed.) Viewing Positions: Ways of Seeing Film. New Brunswick, N.J.: Rutgers University Press, 1995; Gunning, T. "The Cinema of Attraction: Early Film: Its Spectator and the Avant-Garde." Stam, R. and Miller, T. (eds.) Film and Theory: An Anthology. Malden, Mass. and Oxford, UK: Blackwell Publishing, 2000. 
Osgerby refers to Gunning's work on the 'cinema of attractions' when he examines spectacular sequences in biker films, but does not develop the point.

This creates an opportunity for further analysis, and the results will contribute to my broader argument about the relationship between the biker film and other action-oriented genres.

\section{Classical Narration in the Biker Film}

The classical mode of narration has been the dominant narrative form in Hollywood for much of its history. Classical films are presented with clear-cut and transparent conventions which were closely followed in the era of studio filmmaking. These conventions include tightly organized narratives, ${ }^{266}$ transparency in their approach, ${ }^{267}$ and coherence in their storytelling. ${ }^{268}$ Classical narrative films also had a degree of stability in terms of story, character identification, and structure. ${ }^{269}$ One of the main characteristics of classical Hollywood cinema is that narrative structure is progressed and developed through causality. As Elsaesser claims, "classical narrative was essentially based on a dramaturgy of intrigue and strongly accentuated plot, which managed to transform spatial and temporal sequence into consequence, into a continuum of cause and effect. ${ }^{, 270}$ Bordwell argues that causality is the prime unifying principle of classical fabula construction. ${ }^{271}$ Causality accounts as the main narrative drive of a classical Hollywood film, and is tied directly to the goal-oriented behaviour of central characters. ${ }^{272}$

\footnotetext{
${ }^{266}$ King, G. Spectacular Narratives: Hollywood in the Age of the Blockbuster. London and New York: I.B. Tauris, 2000. 28.

${ }^{267}$ Plantinga, C. Moving Viewers: American Film and the Spectator's Experience. Berkeley, Los Angeles and London: University of California Press, 2009. 85.

${ }^{268}$ Stam, R., Burgoyne, R. and Flitterman-Lewis, S. New Vocabularies in Film Semiotics: Structuralism, Post-Structuralism and Beyond. London and New York: Routledge, 1992. 188.

${ }^{269}$ Kramer, P. "Post-classical Hollywood." Hill, J. and Church Gibson, P. (eds.) American Cinema and Hollywood: Critical Approaches. Oxford: Oxford University Press, 2000. 63.

${ }^{270}$ Elsaesser, T. "The Pathos of Failure: American Films in the 1970s: Notes on the Unmotivated Hero." Elsaesser, T., Horwath, A. and King, N. (eds.) The Last Great American Picture Show: New Hollywood Cinema in the 1970s. Amsterdam: Amsterdam University Press, 2004. 280.

${ }^{271}$ Bordwell, Narration in the Fiction Film, 157.

${ }^{272}$ Stam, Burgoyne and Flitterman-Lewis, 189.
} 
In classical narration, particular attention is put on "personal psychological causes: decisions, choices, and traits of character." ${ }^{273}$ The main causal agent in classical cinema is the protagonist, which Bordwell calls the most "specified" character, and "[t]he principal causal agency" of classical narratives, who is usually "a discriminated individual endowed with a consistent batch of evident traits, qualities, and behaviours." 274 These traits include being heroic, as well as "mature, active, efficient, graceful, and stoic," 275 and elicit strong identification from the spectator. ${ }^{276}$ Elsaesser also asserts that classical narratives contain an implicit causality that envelops the psychologically and emotionally motivated hero and connects him to his world. ${ }^{277}$ Bordwell develops this point further: "Within the classical scene, characters act and react according to principles of individualized character psychology. They struggle, collide, and make decisions." ${ }^{278}$ Classical narrative films usually provide a sense of completion for their audiences, often through the resolution of conflicts and knowledge of the fate of the characters, but also by joining the (heterosexual) couple. ${ }^{279}$

Although the biker films concern the behaviour of gangs, they usually establish individual, goal-oriented characters for the audience to identify with. These can be either biker or non-biker characters. For instance, there are examples of characters that are motivated by revenge, such as Shayne in The Mini-Skirt Mob, Johnny in The Savage Seven, Dan in Hell's Belles and Mitch in Chrome and Hot Leather. Shayne is jealous of her former boyfriend Jeff's relationship with his new partner Connie, and tries throughout the film to win back his affections. After she realises this will not be possible, Shayne's motivation turns to taking revenge on Jeff and she becomes determined to kill both Jeff and Connie. In Hell's Belles Dan takes revenge against the biker gang for stealing his precious motorcycle, and he pursues the gang across the desert and attacks them a number of times as he tries to retrieve it. The non-biker protagonist Mitch in

\footnotetext{
${ }^{273}$ Bordwell, D. and Thompson, K. Film Art: An Introduction (Seventh edition). New York: McGraw-Hill, 2003. 89.

${ }_{274}$ Bordwell, Narration in the Fiction Film, 157.

${ }^{275}$ Kramer (2000), 67.

${ }^{276}$ King, G. (2000), 29.

${ }^{277}$ Elsaesser, 280.

${ }^{278}$ Bordwell, The Classical Hollywood Cinema, 65. This book has three authors. Further references specify the writer responsible for the particular passage being acknowledged.

${ }^{279}$ Bordwell and Thompson, 90-91.
} 
Chrome and Hot Leather is motivated entirely by revenge after one member of the biker gang causes the car-crash death of his fiancé after she is terrorised by the biker and his gang.

Some protagonists also undergo a degree of change or try to 'reform' in these films, such as the lead biker characters in Angel Unchained and Run Angel Run! Character change, Greg M. Smith argues, is a trait of classical narration: "The classical cinema is usually concerned with change in its protagonists. Along the way to achieving the overt narrative goal, classical protagonists must often undergo character change themselves. The internal change makes the achievement of the action-oriented goal possible." ${ }^{280}$ In Angel Unchained, for example, protagonist Angel makes a decision to leave his biker gang and ends up in a hippie commune in the desert. He soon decides to stay there and live a peaceful life. Angel's main motivation in the film, however, turns to helping protect the commune from the antagonistic townspeople who regularly attack the hippies. The character change in J.C. in the film J.C. works somewhat differently. For the majority of the film J.C. is fairly peaceful and mild mannered, even in scenes in which he preaches about standing up against authority. However, after a close friend of his is viciously beaten in police custody, J.C. becomes angry and vows to take revenge on the police responsible. This revenge motivation culminates in a violent and fatal conflict between the police and J.C.'s biker gang. In this instance, J.C. moves from being a rebellious and non-conformist hippie to a violent and vengeful outlaw biker. His appearance and lifestyle suggest that he is a hybrid of the two, but his change in character emphasises the contrast in the two different cultures he seemingly, at once, represents.

Classical Hollywood narratives generally consist of two plot lines, or two lines of action, which act as a double causal structure of the classical syuzhet. ${ }^{281}$ One of these lines commonly involves a romance subplot, which occurs throughout classical Hollywood cinema: "85 per cent of Hollywood movies feature

\footnotetext{
${ }^{280}$ Smith, G.M. Film Structure and the Emotion System. Cambridge: Cambridge University Press, 2003. 55.

${ }^{281}$ Bordwell, Narration in the Fiction Film, 157.
} 
heterosexual romance as their main plot device." 282 The other line is a business plot - "another sphere" which could include "work, war, a mission or quest, other personal relationships." ${ }^{, 283}$ There are some biker films which contain the presence of romance or a romantic line of action. There is a romantic dimension in Hell's Belles, The Mini-Skirt Mob, The Savage Seven, Run Angel Run!, Angel Unchained, Hell's Bloody Devils, C.C. and Company, and Angels Hard as They Come. Perhaps the most explicit example of the romantic storyline can be found in the romantic montages in some films. These focus on the developing relationships of characters such as Angel and Laurie in Run Angel Run!, C.C. and Ann in C.C. and Company, as well as Angel and Merilee in Angel Unchained. Maltby argues that a large number of classical films also end with a display of the united romantic couple. ${ }^{284}$ This classical element can be identified in The Mini-Skirt Mob, Run Angel Run!, Wild Wheels and C.C. and Company. In the latter example, C.C. and Ann's romance lasts until the final scene, where they enact their revenge against the biker gang and subsequently ride off into the night together.

However, even though romance is featured in some biker films, the role it plays is not always causal. This is due to the fact that the romantic lines of action may be brief and the spectator may not be consistently reminded of this storyline. Indeed, the narration of biker films can be disjointed in this regard, such as in the brief romance between Long John and Astrid in Angels Hard as They Come. These elements of the narrative are thus isolated incidents and situations when compared to the rest of the onscreen subject matter in the wider narrative. While classical in origin, the usage of these elements also points to the fragmented, post-classical narrative structure of biker films.

The biker film may also be considered 'classical' in regards to what Bordwell calls a 'typical' scene and how it operates within the narrative. In terms of dramaturgy, he argues that the classical Hollywood scene contains two processes: "First, it continues, develops, or closes off lines of cause and effect

${ }^{282}$ Maltby, R. "The Classical Hollywood Cinema." Hollows, J., Hutchings, P. and Jancovich, M. (eds.) The Film Studies Reader. London: Arnold, 2000. 168.

${ }^{283}$ Bordwell, Narration in the Fiction Film, 157.

${ }^{284}$ Maltby, 167. 
previously left open...Or the previous causal line may be completed."285 This is identifiable in many biker film scenes in which the main characters have a clear causal role. For instance, Mitch in Chrome and Hot Leather does not stop pursuing the biker gang who killed his fiancé until they are either dead or captured at the end of the film. The majority of scenes preceding the film's finale continue and develop this causal plotline. Bordwell argues that the other purpose of a scene in classical cinema "is to open and perhaps develop at least one new causal chain. Against the backdrop of old lines of action, the scene initiates new conflicts, new goals, new questions." ${ }^{286}$ An example of this in the biker film would be when Nutty rapes and kills a girl in Angels from Hell. This action begins a new conflict with the gang and the police, and also internally within the gang. Similarly, once Angel in Angel Unchained has achieved his initial goal of escaping the gang he once rode with and retiring to a desert commune, the commune comes under attack from townsfolk whom he must now protect (especially as he has started a relationship with Merilee, a member of the commune). The development of new causal chains is especially evident in scenes where revenge because a key motivation for biker film characters, such as in Chrome and Hot Leather, Run Angel Run!, The Mini-Skirt Mob and The Savage Seven.

It is also appropriate to consider the role of style in classical cinema. Generally, style facilitated storytelling in an unobtrusive manner. "Characteristically, Hollywood's style effaced the techniques of making the film (or else recuperated them into the story line). It was a cinema of concealed artifice. Rather than a display of the apparatus and art of filmmaking, the standard was the story and what was lifelike, or verisimilar." ${ }^{, 287}$ In terms of visual style and editing patterns, classical narration uses various strategies, such as the continuity editing system.

Within the classical scene, the viewer assumes durational continuity unless signals say otherwise. The individual shot is assumed to convey a continuous time span which only editing can disrupt. Yet the classical

\footnotetext{
${ }^{285}$ Bordwell, The Classical Hollywood Cinema, 64.

286 Ibid.

${ }^{287}$ Staiger, Ibid., 109.
} 
cinema is a cinema of cutting; the single-shot sequence is very rare. Thus classical editing strategies have to signal temporal continuity. ${ }^{288}$

Classical narration also uses stylistic strategies such as the establishing shot and master shot in order to establish and maintain screen space. ${ }^{289}$ The initial establishing shots are generally followed by two-shots, and then followed by shot/reverse shots or eyeline-matched medium shots, which keep the figures in the same scale in both shot and countershot. ${ }^{290}$

Shot-reverse-shot cutting assumes that the series of shots alternates a view of one end-point of the line with a view of the other...Eyeline-match cutting uses character glance as a cue to link shots. The assumption is that the eyeline runs parallel to the axis, so the camera positions will remain on one side of the line. ${ }^{291}$

Therefore, the characters' activity is the basis of the construction of $180^{\circ}$ space. These classical methods feature at times in the biker film narrative, but are perhaps most identifiable in the reflection scenes. This is when two characters interact with each other in romantic subplots, also during some of the calmer moments of these films. These scenes contain conversations that use the stylistic techniques found in classical cinema. Some examples include Run Angel Run!, Angels Hard as They Come and C.C. and Company.

\section{Post-Classical Narration in the Biker Film}

This chapter will now look at the post-classical narrative elements of these films. Kramer asserts that the traditional form of American cinema came to an end in the 1950s. ${ }^{292}$ Kramer continues by arguing that the post-classical Hollywood cinema contrasted with the "aesthetic and institutional homogeneity and stability of classical Hollywood,"293 and was influenced by the rise and popularity of post-war European art cinema. ${ }^{294}$ During the 1960s a different kind of American cinema emerged. It was marked by weaker causality, or by

\footnotetext{
${ }^{288}$ Bordwell, Ibid., 46.

289 Ibid., 66.

${ }^{290}$ Ibid.

${ }^{291}$ Ibid., 57.

${ }^{292}$ Kramer (2000), 69.

293 Ibid., 63.

${ }^{294}$ Ibid., 69.
} 
what Elsaesser calls the "fading confidence in being able to tell a story." 295 As this chapter will show, the post-classical elements in the biker film are more prevalent than the classical elements. We will explore the prevalence of postclassical elements in the narrative structure of these films in three ways. Firstly, we will consider Elsaesser's work on the unmotivated hero in 1970s cinema in regard to the biker film. Secondly, we will discuss the role of spectacle in these films, with a focus on the type of spectacle found in contemporary action films. Finally, we will examine the function of the spectacular scenes as 'attractions', with specific analysis on Gunning's work on the 'cinema of attractions'.

There are connections that can be made between the protagonists of New Hollywood and those found in the biker film. Douglas Gomery argues postclassical and European-influenced films instead feature more confused, ambivalent and alienated characters than classical Hollywood cinema, and they do not have clear goals or motivation towards those goals. ${ }^{296}$ Elsaesser asserts that in New Hollywood characters there is a "lack of corresponding motivation on the inside, on the part of the protagonist's inner drive or palpable conflict."297 Protagonists in these films, he argues, bring a sense of inconsequential action, pointlessness and uselessness to the narrative. ${ }^{298}$ Characters and films in this respect are "affected by the crisis of motivation." ${ }^{299}$ Elsaesser also says of characters in 1970s American cinema: “Today's heroes are waiting for the end, convinced that it is too late for action, as if too many contradictions have cancelled the impulse towards meaning and purpose."300 This section of the chapter will argue that the characters in biker films also often have problems with motivation, and that this is apparent in their tendency to be more interested in their lifestyle of non-conformity than doing anything else. Indeed, these characters sometimes talk about not wanting to do anything else, which reflects the aimlessness of their lives. The crisis of motivation also remains unresolved

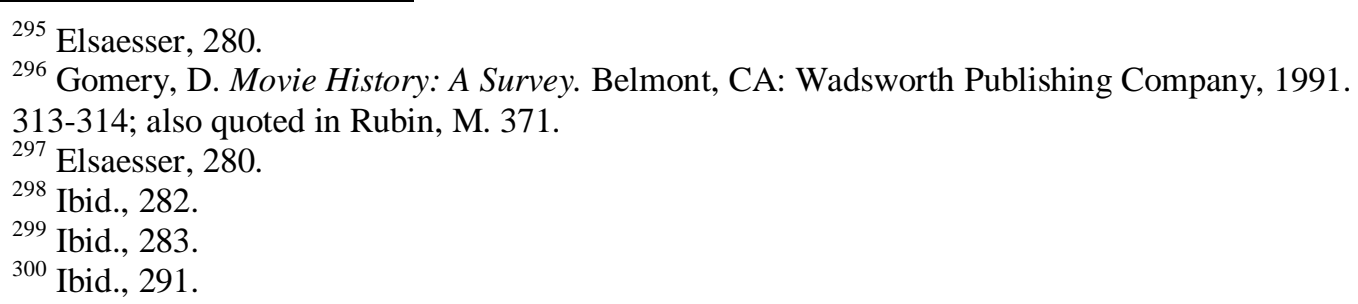


through the empty and nihilistic endings of several biker films, which I will discuss below.

Greg M. Smith argues that a protagonist's past and back-story is crucial for character identification in classical narrative, and is tied to motivation: "The characters must have a coherent psychological motivation that drives them toward achieving a goal, and this motivation frequently comes from the characters' past." ${ }^{, 301}$ Warren Oates's character Benny in Bring Me the Head of Alfredo Garcia (1974) is an example of a hero with no past to romanticise. ${ }^{302}$ This is also true of the Driver, Mechanic and Girl in Two-Lane Blacktop. We learn nothing of their backstory and they appear to exist solely within the films' narrative parameters. While GTO seems to provide information about his past, it is uncertain to what extent we should believe him. Most 1960s biker films provide little if any detail about the characters' past. The majority of biker characters merely live to ride, fight, rape, steal, and hate. The bikers rarely stray from their lurid lifestyles, and although a few bikers undergo change in these films, most remain freewheeling motorcycle-riding rebels engaged in a life of non-conformity and crime. They can be seen as unmotivated characters that exist to engage in the violent and anti-social behaviour depicted onscreen. The biker characters furthermore appear unmotivated because they talk about not wanting to do anything. They would instead rather be 'free' and live an easy life. This presents a crisis of motivation for these characters, because to be free, in this respect, is to be unmotivated, and unconstrained from life and the achievement of goals. These traits are evident in biker characters featured in The Wild Angels, Run Angel Run!, Angel Unchained, The Savage Seven, and Hell's Angels on Wheels. In the funeral scene of The Wild Angels, Heavenly Blues tells the Priest - who asks him "What is it you want?" - that "We want to be free. We want to be free to do what we want to do," aptly said before his gang destroy the inside of the church. This sentiment is mirrored in Run Angel Run! when Angel is talking with Dan. Dan says his life with bikes and gangs is gone, and that family and home life is more important to him, to which Angel replies "not me, man. I gotta be free, I gotta fly. Like that bird up there." Similarly, in

\footnotetext{
${ }^{301}$ Smith, G.M., 161.

${ }^{302}$ Elsaesser, 284.
} 
C.C. and Company, C.C. tells Ann that he "dug the freedom" of being with the biker gang.

These problems with motivation are significant because they influence narrative structure. If a character is unmotivated then the narrative can appear inconsequential, fragmented and even episodic. As Bordwell argues, "[e]quivocating about character causality supports a construction based on a more or less episodic series of events. If the Hollywood protagonist speeds toward the target, the art-film protagonist is presented as sliding passively from one situation to another." ${ }^{\prime 303}$ The unmotivated characters make the narrative structure of biker films feel, as Osgerby asserts, "fractured and fragmented." 304 Rubin also argues that many biker films have weak narratives when compared to the standards of classical Hollywood, and "their loose structures... [differentiate] them from the narrative tightness and romantic lyricism of their progenitor, The Wild One, despite their heavy indebtedness to many of its plot elements." ${ }^{305}$ Biker film critics see the structure of biker films are nothing more than "a series of brutal episodes,"306 and "a series of loosely connected vignettes illustrating a lifestyle and culminating in a final, nihilistic tableau." ${ }^{307}$ Examples of this can be found most prominently in biker films that contain a large number of spectacular scenes such as riding, fights and wild parties. The frequency of riding scenes in Hell's Angels '69, C.C. and Company and Angels Hard as They Come, make the overall structure of the narrative appear episodic. These scenes convey little information and seem to act purely as scenes of spectacle and 'attractions'. There are numerous fight scenes and celebration sequences in biker films. These disrupt the narrative flow as the films seem to pause to observe or even indulge in the more notorious aspects of biker lifestyle. I discuss these sequences in detail in the last section of this chapter.

\footnotetext{
${ }^{303}$ Bordwell, Narration in the Fiction Film, 207.

${ }^{304}$ Osgerby, B. 'Sleazy Riders; Exploitation, 'Otherness,' and Transgression in the 1960s Biker Movie.” Journal of Popular Film and Television. Vol. 31, No. 3. (Fall 2003.) 105.

${ }^{305}$ Rubin, M., "Make Love Make War: Cultural Confusion and the Biker Film Cycle." Film History. Vol. 6, No. 3. (Autumn 1994.) 365-366.

306 Osgerby, 98.

${ }^{307}$ Rubin, M., 369.
} 
The endings of biker films also involve a departure from classical narration. Whereas classical Hollywood cinema contains climaxes that possess narrative closure and romantic unity, biker films often have finales which are more detached, empty and even apocalyptic. Rubin argues, "biker films (especially those with biker protagonists) seem to progress not so much toward a strong psychodramatic resolution based on conflict and identification as toward a type of distanced, emblematic final shot that could be called the "nihilistic tableau. ",308 Biker films thus tend to reinforce Elsaesser's view that New Hollywood cinema is characterised by 'the pathos of failure. ${ }^{309}$ This type of ending features in a number of biker films, usually in the form of death and disillusionment. One variation involves the death of a biker, often the leader. For example, Keeg and Mike, the biker leaders from The Cycle Savages and Angels from Hell respectively, are both shot and killed whilst riding off on their bikes. In other examples, biker films sometimes end with the death of a good character, such as counterculture commune leader Tremaine in Angel Unchained and Chuck in Hell's Angels '69. With these deaths, a sense of nihilistic pathos ensues in these final scenes.

The mood conveyed by these final tableaux is often apocalyptic, the sense of closure relatively weak, the future bleak and uncertain, the fates of the main characters largely unresolved, the moral outcome clouded, the earth scorched, the feeling of futility overwhelming. ${ }^{310}$

This can also be discerned in a range of biker films ending in confusion and disillusionment. These include Hell's Belles, Run Angel Run!, and The Wild Angels. In Hell's Belles, Dan fails to tempt reforming biker girl Cathy away from her biker lifestyle. Instead, she returns to the injured biker leader Tampa instead of leaving with Dan, whom she has been growing feelings for throughout the film. In the final scene of The Wild Angels, Heavenly Blues stands alone by Loser's grave. He shovels earth into the grave while police sirens becoming increasingly louder as they close in around him. He chooses not to flee and seems resigned to what may follow. What these final scenes

\footnotetext{
${ }^{308}$ Rubin, M., 367.

${ }^{309}$ Elsaesser, 287.

${ }^{310}$ Rubin, M., 369.
} 
convey is that whatever goals that had been set by these characters have ultimately not been achieved, and have failed.

\section{The Biker Film as a Cinema of Attractions}

A number of writers have pointed to the relationship between contemporary action cinema, spectacle and the 'cinema of attractions.' Plantinga suggests that this is a trend that many post-classical narratives follow, by placing spectacular scenes before narrative fluidity and strong characterization. "[T]he "new Hollywood'... has forsaken the evocation of deep emotion characteristic of classical Hollywood for the surface amusements of spectacle." ${ }^{311}$ Kramer also claims that a "lack of concern for coherent storytelling... was matched by the audience's enthusiastic response to spectacular attractions and shock effects, irrespective of their degree of narrative motivation." 312 King contends that narrative causality and momentum in Hollywood blockbusters is "bracketed" by spectacle, ${ }^{313}$ and "displaced" by thrilling set-pieces. ${ }^{314}$ These arguments about spectacle in the contemporary Hollywood blockbuster can be linked to the kind of narrative disruption caused by spectacle found in the 1960s biker film.

The spectacle found in the contemporary action film predominantly revolves around special effects and action sequences, but also takes other forms such as the focus on "star bodies... artful editing and percussive music." 315 Tasker argues that the main formal expectations of a contemporary action scene include elements such as chase scenes, combat, a distinctive arrangement of space, an accelerated sense of time and pace through editing or camerawork, as well as in visual and aural spectacle, and special or digital effects. ${ }^{316}$ It is through the focus on male violence that the biker film can be associated with the action film - we will explore this issue further in chapter four. In terms of special effects and the contemporary action film in general, Tasker maintains that

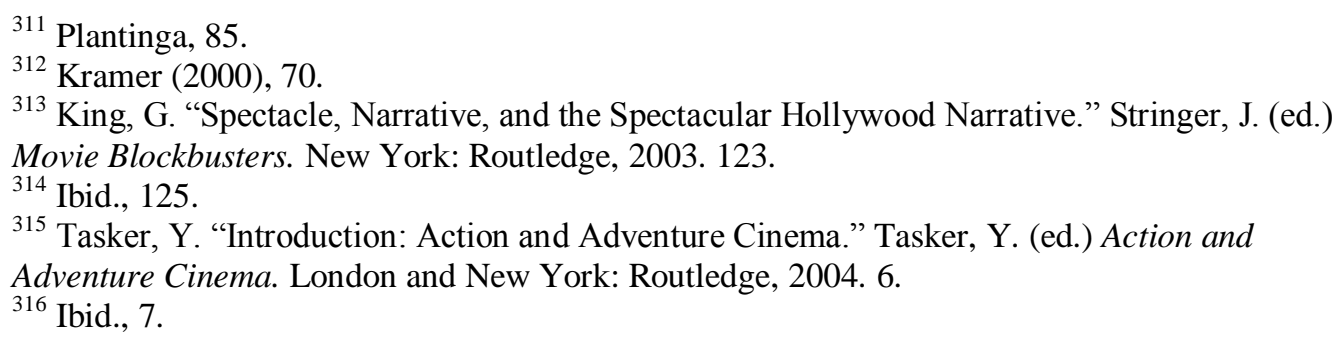


critics repeatedly single out for comment the exaggeration or stylisation, the sheer excess of spectacle as the defining feature of contemporary action. High-profile action and adventure movies do indeed provide a testing ground for visual innovations and special effects: this is perhaps the generic terrain on which the impact of CGI is most evident. ${ }^{317}$

The 'cinema of attractions' dominated film from its origins in the late $19^{\text {th }}$ century until about 1906-7, ${ }^{318}$ and "appealed to audiences primarily through simple comedy and melodrama, trick effects, exotic scenery, and other forms of spectacle." 319 In the 'cinema of attractions', the film image engages and stimulates the viewer's curiosity through the act of looking, rather than absorbing their spectators into watching sustained narratives. ${ }^{320}$ Gunning claims that this was a type of cinema in which " "energy moves outward towards an acknowledged spectator rather than inward towards the character-based situations essential to classical narrative." ${ }^{321}$ Gunning also calls it "a cinema that bases itself on the...ability to show something...this is an exhibitionist cinema...that displays its visibility." 322 The early films of Méliès, for example, operate "less as a way of telling stories than as a way of presenting a series of views to an audience, fascinating because of their illusory power." ${ }^{223}$ Examples of the type of spectacle cinema in this period include the trick film, which Gunning defines as "a series of displays, of magical attractions, rather than a primitive sketch of narrative continuity. Many trick films are, in effect, plotless, a series of transformations strung together with little connection and certainly no characterization." 324 These 'plotless' displays may be without coherent story and/or strong characterization, but they nonetheless engage the viewer's curiosity through visual devices designed to solicit a highly conscious awareness of the image. ${ }^{325}$ This chapter will argue that the various scenes of

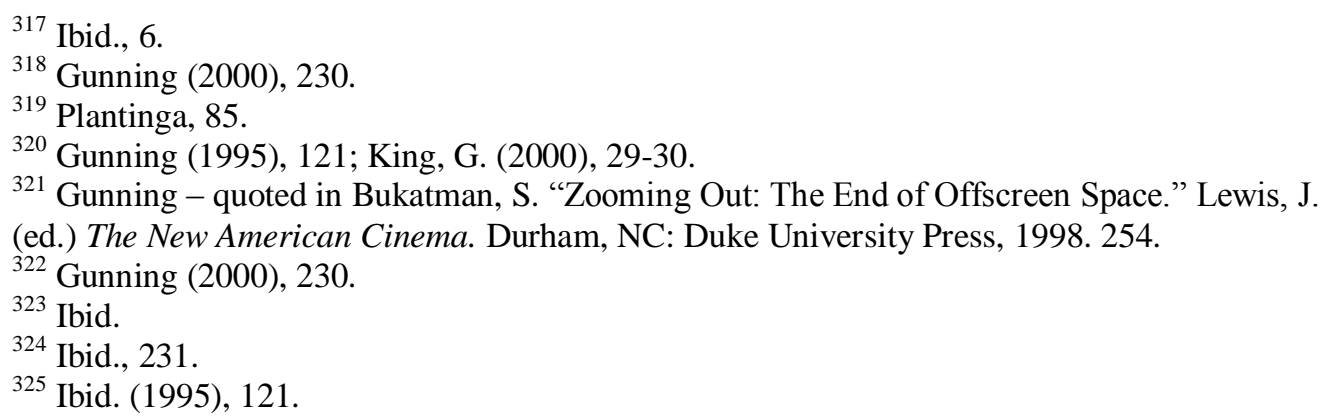


spectacle in the biker film function as 'attractions' in Gunning's sense, because, for one thing, such a large number of these types of scenes feature in the biker film.

The 'cinema of attractions' also directly approaches and addresses its spectator through confrontation, and, in some terms, elicits shock from its audience. This procedure of confronting the viewer with shock can perhaps first be seen in Lumière's Arrival of a Train at the Station (1896), which, as Gunning asserts, provoked a "terrified reaction of spectators [who] reared back in their seats, or screamed, or got up and ran from the auditorium (or all three in succession)." This shock and thrill, or what Gunning calls "the aesthetic of astonishment" was designed to capture the same emotions of its audience through this confrontation: "The directness of this act of display allows an emphasis on the thrill itself - the immediate reaction of the viewer." 327 The viewer, in this instance, is "aroused and fulfilled through a marked encounter, a direct stimulus, a succession of shocks." ${ }^{328}$ The scenes of spectacle in biker films also resemble these 'attractions' through their ability to shock, specifically through scenes of brutality and violence, as they confront the audience with taboo subject matter about brutal men indulging in controversial activities and episodes that would perhaps have been considered shocking to some audiences at the time.

Rubin and Osgerby have written about spectacle in the biker film by linking it to the spectacle found in early cinema and 'cinema of attractions.' Rubin argues that " $[\mathrm{b}]$ iker films frequently give the impression that they are being addressed to an audience that cares little about plot and mainly wants to see big guys riding around on big motorcycles, knuckles colliding with noses, and women, both pure and tainted, being treated like dirt." ${ }^{329}$ Therefore, he maintains, biker films seem to have "regressed to the earliest days of film history...when...the sheer spectacle of recorded motion was attraction enough to constitute a cinematic experience." ${ }^{, 330}$ Osgerby also believes that these biker films resemble

\footnotetext{
${ }^{326}$ Ibid., 114.

${ }^{327}$ Ibid., 122.

${ }^{328}$ Ibid., 123-124.

${ }^{329}$ Rubin, M., 365.

${ }^{330}$ Ibid.
} 
the 'cinema of attractions,' but are closer to the classic exploitation films of the 1930s, which he discusses in much greater length. ${ }^{331}$ "Like classical exploitation cinema...[biker films] privileged exhibition over narrative, spectacle over intellect. ${ }^{, 332}$ Much of this spectacle is exhibited through the lawless behaviour of marauding bikers. Biker films, like 1930s exploitation films, celebrate their sensationalism and exploit the audience's "voyeuristic fascination for terrifying 'Otherness' and disruptive excess." ${ }^{, 333}$ Osgerby contends that both kinds of film place an "emphasis on a spectacle of the forbidden working to usurp the conventions of 'respectable' filmmaking and flout mainstream taboos." „334

All the biker films noted in this thesis appear to contain at least two fight scenes. ${ }^{335}$ However, there are some films that contain numerous fight scenes, which are sometimes spread out throughout the whole film but occasionally occur in quick succession. Hell's Angels on Wheels, Angel Unchained, Hell's Belles, Chrome and Hot Leather and The Savage Seven are examples of biker films where this occurs. These films contain between four and six fight scenes each. This type of scene is usually made up of various moving camera shots and angles to give the impression and experience of a rough and kinetic brawl. These fights also occur at the end of the films in spectacular form. For example, the assault on the town by the bikers at the end of The Savage Seven is a lengthy sequence between the bikers and the population of the town, which is mostly made up of Native Americans. This sequence contains several stunts and explosions, such as bikers flying through windows after crashing their bikes. This specific scene results in the injury or death of several characters, which reinforces the impression of violent spectacle in the closing phases of biker films. A similar type of scene can be found at the end of Angel Unchained, in which a group of rednecks launch an attack on the hippie commune which is being protected by ex-biker Angel's old gang. This scene also contains numerous stunts and moments of destruction, such as vehicles colliding with

\footnotetext{
${ }^{331}$ Osgerby, 98.

332 Ibid.

${ }^{333}$ Ibid., 103.

${ }^{334}$ Ibid., 105-106.

${ }^{335}$ Films including two or three of these fight scenes include The Cycle Savages, J.C., Satan's Sadists, Angels from Hell, The Rebel Rousers, Angel's Hard as they Come, The Mini-Skirt Mob, Wild Wheels, Run Angel Run!, Hell's Angels '69, Hell's Bloody Devils and C.C. and Company.
} 
other vehicles and people, and, in one instance, a buggy flying through the air, crashing into a building and exploding spectacularly.

In terms of reading these fight scenes as 'attractions,' one can also examine the visual style of these scenes. Shaky, kinetic camerawork and oblique angles are examples of how visual style can be seen as an 'attraction' in these fight sequences. In the fight scene between Keeg and the artist in The Cycle Savages, there are some jerky shots as well as a POV angle of Keeg attacking the artist by knocking him unconscious with his boot. There is a bar fight in The Savage Seven between the biker gang and a group of townspeople which also incorporates similar camerawork in order to achieve an exciting and kinetic visual style. A POV shot occurs in this scene when one biker Bull is about to stamp on the head of an opponent. This could create a moment of shock for the viewer. In terms of visual style, fast-paced editing also makes biker film fight scenes seem like 'attractions,' such as during a different fight sequence in The Cycle Savages involving Keeg and another motorcycle rider in a waterfront park.

Another way of reading these scenes as 'attractions' is through their audio style, especially in the music that accompanies them. Rubin sees this music as being out of place with the violent onscreen behaviour: "There are fistfights a-plenty in biker films, but these tend to be oddly weightless affairs, lacking a sense of brutality and frequently accompanied by incongruous-seeming bubbly music." 336 Upbeat music that diminishes the brutality and intensity of these fight sequences is common in the biker film. Although it seems incongruent, this music increases the spectacle of these scenes and their roles as 'attractions.' One example happens in The Mini-Skirt Mob, specifically during the fight between Lon and Jeff outside Jeff's Winnebago early in the film. In The Savage Seven, upbeat, merry music is heard during the fight between biker leader Kisum and town henchman Tiger. In The Savage Seven during the bar fight between the Hell's Angels and a rival gang, jaunty, animated music plays on the soundtrack, which makes this sequence less intense but more spectacular due to its tonguein-cheek melody.

${ }^{336}$ Rubin, M., 366. 
The rape and sexual violence episodes also function as an 'attraction' in the biker film. "Rape (especially gang-rape) is a central ingredient of the Hell's Angels mystique and an important contributor to the exploitation appeal of the biker film. ${ }^{, 337}$ The subject of rape is common across the biker film cycle and can be regarded as 'attractions,' even if some rape scenes are not represented graphically. The first film in the 1960s biker genre, The Wild Angels, contains two rape scenes. The first involves an attack on a black nurse. The second occurs when the widow of deceased biker Loser is violated in a church during his funeral. The Born Losers is perhaps the biker film where rape "receives its most extended and questionable treatment," and has a narrative that seems like a "non-stop series of rape situations." ${ }^{, 338}$ Rape and sexual violence scenes feature prominently in The Wild Angels, Satan's Sadists, The Cycle Savages, The Savage Seven, Run Angel Run!, Angels from Hell and Angel Unchained. The Cycle Savages contains a prolonged and brutal gang rape of a girl in the biker gang's headquarters. This sequence is mostly shot from the POV of the girl, as Keeg and the other bikers descend on her while she lies helplessly on the floor. The trauma of rape is heightened by the combination of dark, sinister music and oblique camera angles. The 'attraction' for the audience here is being placed in the role of the victim.

These sexual attacks on young women sometimes provide a catalyst for subsequent violence as people seek to take revenge on the rapists. Although revenge functions as a character goal and can be read as a classical element in these films, the resulting violence is often spectacular and therefore also works as an 'attraction.' One such example is The Savage Seven, where the rape of a Native American girl leads to the final violent confrontation between the bikers and the Native Americans. Upon learning of this attack, the Native Americans confront the bikers and force them out of town. The Native Americans then 
enact revenge on Bull, the biker who raped the Native American girl, which acts as the catalyst for the final violent confrontation. ${ }^{339}$

Perhaps the most common of the 'attractions' in the biker film are the riding scenes, which include riding montages, chase and race sequences. Rubin claims that there is an "extraordinary amount of screen time that many of the films devote to footage of bikers...just...riding around...on their bikes...hair streaming, mamas clinging, highways unrolling, cameras trucking and zooming, usually while an insipid rock song drones on the soundtrack." ${ }^{340}$ The biker films containing the most riding scenes that this study has found are C.C. and Company - which has nine - and Run Angel Run! and Angels Hard as They Come, which both have seven riding sequences. Other biker films with up to five separate riding scenes include Hell's Angels '69, The Mini-Skirt Mob, Wild Wheels, Chrome and Hot Leather, Angel Unchained, Hell's Bloody Devils, Hell's Angels on Wheels and J.C. Many riding montages take place at the beginning of these films or during the opening credits. The placement of riding scenes occurring at the start of these films is an effective way to introduce the gang, but also exhibits a prominent feature of their notorious lifestyle. Hell's Angels on Wheels and Hell's Bloody Devils exhibit an entire biker gang riding around on their bikes during their respective opening sequences. However, these montages can occur at just about any point in these films and these sequences celebrate the bikers' love of mobility, which is reinforced by a lively musical soundtrack (another source for the 'attraction' qualities of these films).

Race and chase sequences are less common in biker films than the riding montage, but can also be identified as scenes of spectacle and 'attractions'. There is a notable race scene in C.C. and Company, in which C.C. races around a motocross circuit, only for the event to be gatecrashed by the biker gang. Angels Hard as They Come and The Rebel Rousers have biker characters racing each other down improvised 'tracks' such as town streets and beaches. Wild Wheels contains a number of scenes of buggies racing each other across sand

${ }^{339}$ Other examples of this rape-revenge scenario appear in Run Angel Run! and Angels from Hell.

${ }^{340}$ Rubin, M., 365. 
dunes on a beach where much of the film is located. Chase sequences, meanwhile, occur more often, notably in C.C. and Company, The Mini-Skirt Mob, Hell's Angels '69, Angels Hard as They Come, Chrome and Hot Leather and Angels from Hell. For example, The Mini-Skirt Mob contains a scene in which antagonists Lon and Shayne chase after Jeff and Connie (who are on foot) around sandy desert scrubland after the latter escape their biker captors. At the end of Hell's Angels '69 there is a long chase sequence which occurs after the biker gang discover that the infiltrating brothers Chuck and Wes have forged a new biker identity in order to rob the Caesar's Palace casino.

The visual and audio style of the riding sequences is also an important aspect of their function as spectacle and thus 'attractions.' The visual style emphasises rapid movement, particularly through tracking shots. POV shots from the rider's perspective often give the audience a sense of participating in the thrill of the 'run.' One of the opening shots in Hell's Bloody Devils is an over-the-shoulder shot of a biker riding rapidly on a highway and riding in between two of his fellow travelling gang members. From this angle and perspective the shot conveys a sense that the viewer is also riding with the biker at high speed, thus creating an exciting 'attraction.' The effect is repeated several times. The final chase scenes in both Hell's Angels '69 and Hell's Belles contain many travelling shots that feel spectacular due to their high speed and variety of camera distances and angles at which they were shot. These, too, can be argued as being 'attractions' as they convey the kineticity of high-speed travel and thus heighten the excitement and thrill of these sequences. This is further heightened by the movement of the camera over uneven, bumpy and dusty desert terrain, such as when Angel and Tremaine are riding along a dusty desert road on dirt bikes in Angel Unchained.

Music also plays a part in heightening the degree of spectacle in these driving scenes. With the aid of a popular pop and rock song on the soundtrack - a musical genre that would be familiar to viewers watching these films at the time - the audio style in these scenes creates added excitement to these alreadyspectacular sequences. Examples of this include Angel Unchained, where a procession of bikers ride down the highway to upbeat music on their way to the 
desert commune to protect it from the antagonistic locals; and Hell's Angels on Wheels, in which the entire title sequence contains upbeat music whilst showing dozens of bikers riding around the urban landscape of San Francisco.

Sequences involving parties are also scenes of spectacle, and thus can also be seen as 'attractions' within the biker narrative. Stylistically, these scenes can appear quite 'psychedelic', both in visual and aural terms. It is colourful lighting techniques and experimental camera angles that give these scenes an hallucinatory quality. The inclusion of an exciting and progressive 1960s pop and rock music adds to the function of these scenes as 'attractions'. The party scenes tend to take on two different configurations: the drunken party scene, which usually occurs outside in a fire lit biker camp, and the biker orgy, which is another example of the biker film's anti-romantic tone. ${ }^{341}$ Both, however, can sometimes interlink with each other. The drunken party scene occurs in The Cycle Savages, The Mini-Skirt Mob, Angels Hard as They Come, The Savage Seven and Chrome and Hot Leather. After two biker gangs - The Dragons and The Angels - arrive in the hippie-occupied ghost town in Angels Hard as They Come, they waste no time in becoming rowdy and raucous, with a party scene involving bikers drinking and urinating to a rock/pop score follows their invasion. Another party scene occurs later in the film at night, with similar music and bad behaviour. The Savage Seven contains a party scene when the biker gang celebrates the fact that non-biker antagonist Fillmore has dropped the police charges he laid against them after their continuing havoc in 'his' small, isolated desert town.

Orgy scenes occur in Wild Wheels, The Savage Seven, Angels from Hell, Hell's Angels on Wheels and C.C. and Company. The biker orgy is "usually set in an Edenic outdoor location, by a lake or a stream, with beer-guzzling bikers and their wanton women lounging in various states of undress and two-backed interaction, seemingly indifferent to such niceties as privacy and comfort." ${ }^{342}$ Rubin calls these incidents Biker Love-Ins. ${ }^{343}$ They blend nudity, casual sex, a

\footnotetext{
${ }^{341}$ Ibid., 366.

342 Ibid.

${ }^{343}$ Ibid., 374.
} 
rock and pop soundtrack and drug use. ${ }^{344}$ These are all attributes related to the counterculture, which recalls the argument made earlier concerning the bikerhippie alliance. Wild Wheels features a drunken orgy scene, which is again accompanied by psychedelic music on the soundtrack. Hell's Angels on Wheels features a sex and drugs party which occurs in the bikers' clubhouse. This party also has a countercultural feel as one biker paints floral art on one woman's chest and on another's stomach, with upbeat psychedelic sitar music accompanying the scene on the soundtrack. In C.C. and Company, the bikers and their women indulge in pot-smoking and kissing around a campfire at night to music reminiscent of Janis Joplin.

\section{Conclusion}

Although the biker film contains some features of classical narration, it is better classified as an example of post-classical narration because its characters lack clear motivation and the films are episodic. Instead, the biker film concentrates on, and even revels in, the controversial lifestyle of the gang characters. The emphasis on spectacle and 'attractions' indicates that the biker film has similarities with contemporary action films. The following chapter will explore this link further through an analysis of the related issues of gender and genre.

${ }^{344}$ Ibid. 


\title{
Introduction
}

\begin{abstract}
Almost from its outset, American film granted primacy to men in the stories that it told. Narrative is driven by action, and if patriarchal ideology asserts that men are the doers (while women are the "doneunto"), then narrative films are inevitably going to focus on men. While women were accorded with a special genre, the woman's film, men had no need for such a ghetto. Everything else that Hollywood produced was automatically a man's film. Regardless of the genre, images of the masculine ideal remained central. ${ }^{345}$
\end{abstract}

The discussion of the formal elements of the biker film in the previous chapter indicated that this genre could be linked to other New Hollywood films, as well as to more recent action films. This chapter will examine how the biker film can be read in ideological terms. We will focus on the closely related issues of gender and genre. In order to do so, we will consider how critics have dealt with two other groups of films associated with New Hollywood cinema, the conservative, 'Right' cycle films and the revisionist Western. We will link all three groups of films with the action film.

\section{Masculinity and the 1970s Right Wing Film Cycle}

In order to analyse the biker film in terms of gender and genre, let us begin with other parts of American cinema during this period. Robert Ray argues that during the late 1960s and early 1970s there were two distinct 'cycles' of American cinema - the Left and the Right. The Left film cycle, Ray claims, refers to "a series of movies intended to appeal to the counterculture's most visible elements." ${ }^{346}$ Films such as The Graduate and Bonnie and Clyde belong to the Left cycle, as they highlight various liberal themes and tropes of the counterculture during this era, including youth rebellion and alienation. The

${ }^{345}$ Benshoff, H.M. and Griffin, S. America on Film: Representing Race, Class, Gender, and Sexuality at the Movies. Malden, MA, Oxford, and Carlton, Victoria: Blackwell Publishing, 2004. 251.

${ }^{346}$ Ray, R.B. A Certain Tendency of the Hollywood Cinema, 1930-1980. Princeton, N.J.: Princeton University Press, 1985. 298. 
Right film cycle, on the other hand, seemed to appeal to a more conservative audience. Some Right cycle films include Bullitt (1968), Coogan's Bluff (1968), Dirty Harry (1971), The French Connection (1971), Walking Tall (1973) and Death Wish (1974). ${ }^{347}$ Right cycle films concentrate on the 'official hero,' such as a policeman, soldier or vigilante. This character's actions are often considered reactionary in comparison to the protagonists of the Left film cycle, as well as being conservative in terms of the historical events of the period. ${ }^{348}$

Writers such as Peter Lev, Dennis Bingham and William Beard also maintain that the Right cycle films are reactionary compared to the Left cycle's more progressive themes. ${ }^{349}$ Bingham argues that the Right films seemed to be reacting against social and cultural movements of the 1960s such as feminism, the civil rights movement, anti-Vietnam protests, a growing youth culture, and the sexual revolution. ${ }^{350}$ Beard, meanwhile, claims that the prosocial stance of the Right films was made

more or less impossible by the climate of moral chaos, and the sense that...American specialness, individual potential, and social optimism have actually collapsed under the weight of assassinations, Vietnam, social disharmony, Watergate, and all the rest. ${ }^{351}$

This was accompanied by an interesting development in the behaviour of the protagonists of right cycle films. In his analysis of Right cycle characters such as Clint Eastwood's 'Dirty' Harry, Paul Kersey in Death Wish and 'Popeye' Doyle in The French Connection, Beard argues that these films put an emphasis on a "violently regressive and even primitive form of conflict resolution and order restoration into the tortured world of liberal defeat and disintegration in early "70s America." 352 It is important, then, to concentrate on the protagonists of the Right films.

\footnotetext{
347 Ibid.

${ }^{348}$ Ibid., 298-299.

${ }^{349}$ Lev, P. American Films of the 70s: Conflicting Visions. Austin: University of Texas Press, 2000. 22.

${ }^{350}$ Bingham, D. Acting Male: Masculinities in the Films of James Stewart, Jack Nicholson, and Clint Eastwood. New Brunswick, N.J.: Rutgers University Press, 1994. 180-181.

${ }^{351}$ Beard, W. Persistence of Double Vision: Essays on Clint Eastwood. Edmonton: University of Alberta Press, 2000. 6.

352 Ibid., 19.
} 
One way in which the optimism and heroism of classical Hollywood heroes was modified by the protagonists of the Right cycle films was through the characters' propensity for violence. This violence also raises issues concerning masculinity. Hilary Neroni claims that violence is inherently linked to masculinity. She argues, "Serving as a fundamental signifier of masculinity, we not only consider violence more the province of men than women, but it is also an activity that inevitably enhances a man's masculinity as much as it would conversely detract from a woman's femininity." ${ }^{, 353}$ In terms of reading the protagonists of the Right cycle films, Thomas Elsaesser contends that these characters seem to have a persona built on violence and brutality, and that their quests are configured as a pursuit for violent justice. He contends that these protagonists were reminiscent of the drive-oriented violent heroes that featured in films from the 1930s and 1950s - albeit "desublimated" versions of those characters and their violence. Thus the Right film cycle protagonists "appear powered above all by the negative energy of resentment, frustration, and spite, seeking to vent its destructive rage under the guise of a law-and-order morality." ${ }^{, 354}$ The characters of Callahan, Doyle and Kersey can be regarded in this manner. These specific characters are all morally and emotionally tortured in some way, and they seek retribution and vengeance for their own personal reasons. Thus the narratives of these films are often organised around, and motivated by, their characters' violent and brutal methods.

Mia Mask claims that both Dirty Harry and The French Connection are “excessively violent” films, ${ }^{355}$ and Don Siegel himself viewed Dirty Harry as being "a wall to wall carpet of violence.", 356 In particular, critics argued that the character of Harry Callahan displayed a violent nature, and an "instinct for

\footnotetext{
${ }^{353}$ Neroni, H. The Violent Woman: Femininity, Narrative, and Violence in Contemporary American Cinema. Albany: State University of New York Press, 2005. 42.

${ }^{354}$ Elsaesser, T. "The Pathos of Failure: American Films in the 1970s: Notes on the Unmotivated Hero." Elsaesser, T., Horwath, A. and King, N. (eds.) The Last Great American Picture Show: New Hollywood Cinema in the 1970s. Amsterdam: Amsterdam University Press, 2004. 282-283.

355 Mask, M. "1971: Movies and the Exploitation of Excess." Friedman, L.D. (ed.) American Cinema of the 1970s: Themes and Variations. New Brunswick, N.J.: Rutgers University Press, 2007. 63.

${ }^{356}$ Siegel - quoted in Kaminsky, S. Don Siegel: Director. New York: Curtis, 1974. 273; also quoted in Smith, P. Clint Eastwood: A Cultural Production. Minneapolis and London: University of Minnesota Press, 1993. 90.
} 
violence." ${ }^{, 357}$ Mask reads Callahan as "violent and headstrong, a renegade and a racist." ${ }^{358} \mathrm{He}$ is a character featuring in "a trilogy of vigilantism, viciousness, and violence." ${ }^{359}$ Meanwhile, Lev argues that The French Connection's narrative takes an approach towards "casual violence," with the film bearing an overall "violent tone." $" 360$ Doyle is seen as having a violent nature due to his tendency to "physically attack" with "masculine force."361 Other Right protagonists possess and display the same characteristics, such as the title character in Joe (1969), who is "bigoted, violent, and pleased with his assault on anyone who is different,"362 and Kersey in Death Wish.

Critics argue that Right film cycle protagonists are involved in vigilantism. They also claim that these characters are primal figures who reject conventional law and order, even though these films often feature protagonists who are policemen or other authoritative figures. David A. Cook contends that the "high quotient of vigilantism" evident in these films and their characters "signaled the death of political liberalism." ${ }^{363}$ Mask claims that some films of the Right cycle feature an individual rogue policeman "who fights crime and injustice according to his own self-regulatory code of ethics. Each of these characters assumes a 'by any means necessary' position when dealing with a flawed criminal justice system." 364 By taking up this position, these authority figures also become vigilante figures.

Films such as Dirty Harry and The French Connection feature characters that are examples of this. Smith argues that in Dirty Harry Callahan embodies "the

\footnotetext{
${ }^{357}$ Bingham, 190.

${ }^{358}$ Mask, 64.

${ }^{359}$ Ibid., 67; for more on Callahan's questionable morality and police tactics, see Banks, C.

Criminal Justice Ethics: Theory and Practice. Thousand Oaks, CA, London and New Delhi:

Sage Publications, 2004. 33.

${ }^{360}$ Lev, 30.

${ }^{361}$ Ibid., 28-29.

${ }^{362}$ Ibid., 25.

${ }^{363}$ Cook, D.A. Lost Illusions: American Cinema in the Shadow of Watergate and Vietnam, 1970-1979. Berkeley: University of California Press, 2002. 192.

${ }^{364}$ Mask, 63.
} 
true American tradition of vigilantism." 365 Callahan uses violent and questionable methods despite the disapproval of his superiors:

Callahan's obsessive and violently ruthless hunting down of Scorpio exceeds by some margin the limits of offscreen police legality...Callahan is shown as an officer for whom respecting the rules of engagement... and following the orders of his superiors are secondary to getting accomplished whatever he sees as his job. ${ }^{366}$

Lev views the character of 'Dirty' Harry as an "out of control," lawless and misanthropic character working by his own means, rules and regulations, outside of the law. ${ }^{367}$ Bingham contends that Callahan "discards an overly civilised, refined, and intellectualized system because it does not recognize and reward male virtues. ${ }^{368}$ In this respect, Doyle in The French Connection shares the same characteristics as Callahan, because he is also "rough" and "uncompromising" and works outside the law. ${ }^{369}$ Berliner claims that Doyle is ambiguous in his role as the film's hero, and calls him the film's "most disturbing site of all." ${ }^{370} \mathrm{He}$ asserts that "[a]lthough the movie encourages us to stand behind our protagonist, it still portrays him as lecherous, reckless, slovenly and lawless. He is also a foul mouthed-drunk who likes to beat up people." ${ }^{371}$ The characters, and their role as heroes, can ultimately be read as ambiguous because although they are dedicated to their police work, they are also flawed both morally and personally.

Another dimension of the Right film cycle's emphasis on the theme of masculinity is an "excessive devotion to men," or its homosociality. ${ }^{372}$ These films are predominantly male focused, dealing with masculine issues and male characters, and this is shown primarily through their violent, anti-authoritarian lifestyles. The protagonists of these films are all male and the action of their

${ }^{365}$ Smith, P. Clint Eastwood: A Cultural Production. Minneapolis and London: University of Minnesota Press, 1993. 106.

${ }^{366}$ Ibid., 90 .

${ }^{367}$ Lev, 31.

${ }^{368}$ Bingham, 186.

${ }^{369}$ Mask, 64.

${ }^{370}$ Berliner, T. "The Genre Film as Booby Trap: 1970s Genre Bending and The French Connection". Cinema Journal. Vol. 40, No. 3. (Spring 2001). 39; also quoted in Mask, 66.

${ }^{371}$ Ibid., 39; also quoted in Mask, 66.

${ }^{372}$ Bingham, 192. 
respective films takes place around them. The masculine quality of the film is also suggested by the titles of some of these films, such as Bullitt (Frank Bullitt), Coogan's Bluff (Walt Coogan), Patton (1970) (George S. Patton), and Dirty Harry (Harry Callahan). This can be linked to the biker film because the majority of biker characters are male and much of the action focuses on these motorcycle riding men. The biker films also often have aggressive or forceful titles.

The concentration on masculinity raises the issue of the role of women in both the Right films and the biker films. Because the Right cycle films are maleoriented, they often involve the abuse of female characters. Women are weak and undeveloped, and victims of physical and sexual violence. Bingham argues that in the films of 1971 female characters appear to fall into two categories. The first was as "perfunctory sex objects," and the other dealt with "the displacement of coded female weaknesses onto institutions and male characters. ${ }^{\text {373 }}$ Right cycle films often marginalize their female characters. Mask contends that "[b]oth Dirty Harry and The French Connection exclude women (except in the most marginal contexts). ${ }^{, 374}$ In The French Connection, for example, there is not a single female character who is given a solid, developed role in the narrative. Most of the film's female characters become victims of male violence. At one point Doyle is attacked by a sniper who hits a young woman with a pram by mistake. Doyle tells members of the public to leave her alone. The viewer learns nothing more about her. ${ }^{375}$

Edward Gallafent argues that Dirty Harry also deals with violence against women, and that the film treats female characters as victims of male sexual and physical violence in a masculine world. ${ }^{376}$ He claims, "The guarantee of Callahan's action rests on his standing against the combination of violence and sexual excitement - the butcher knife and the hard-on."377 Mask presents a similar argument, contending that women and their sexual vulnerability operate

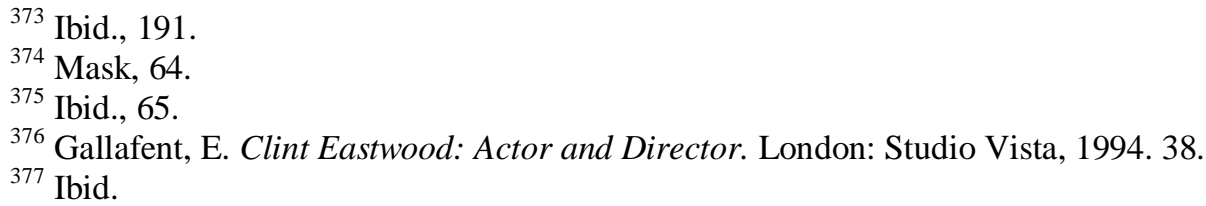


as a pretext in Dirty Harry. ${ }^{378}$ For example, in the opening scene of Dirty Harry, Scorpio shoots his first victim, an attractive young woman in a rooftop swimming pool. "The movie's opening sequence shows the killer's gun barrel close up and his view of her in the sights of his high-velocity rifle, before a single bullet enters her neck and she sinks beneath the water." ${ }^{379}$ Later in the film, another girl that Scorpio abducts is eventually found asphyxiated in a small underground hole, the victim of a slow and painful death. It is also significant that Harry's wife was killed by drunk driver. Lev regards Harry's fanaticism and sadistic nature as a compensation of his grief from this incident, suggesting that "his tough, unyielding, unfeeling side stems from [this] personal tragedy. ${ }^{, 380}$ Harry's wife, therefore, is represented as just another victim in the male-oriented course of this narrative. This treatment of female characters reaches an extreme in Death Wish. Kersey's wife and daughter also become victims of male physical and sexual violence: his wife is murdered and his daughter is raped and subsequently reduced to state of catatonia. One of the implications of this is that the sexual violence in Death Wish arguably has a voyeuristic quality to it. Something similar occurs in Dirty Harry, both in the opening sequence and subsequently in two scenes in which Harry looks through windows of women getting undressed.

\section{Gender and the Biker Film}

We can read the biker films and their characters in a similar manner to the Right cycle films because many appear to have a heightened or exaggerated masculinity. This is because the protagonists in the biker film have a propensity for physical and sexual violence, as we saw in the previous chapter. While many biker films contain characters who engage in casual violence such as The Wild Angels, Hell's Belles, and Angel Unchained, even more extreme and sadistic biker characters can be found in films such as Satan's Sadists and The Cycle Savages. As well as violence, the biker characters are also involved in other types of criminal behaviour and generally have a disregard for authorities and institutions. Even though Callahan and Doyle are policemen and the bikers are

\footnotetext{
${ }^{378}$ Mask, 69.

${ }^{379}$ Smith, P., 121.

${ }^{380}$ Lev, 34.
} 
criminals, these two groups can be connected by their flouting of and disregard for the law.

The biker film can also be linked to the Right film because both are male centred. Indeed, homosociality is arguably more prominent in the biker film because much of a typical biker narrative focuses on the biker as being part of a predominantly male group or ensemble. Generally, the male biker characters ride, brawl and live together in groups rather than as individuals. The male characters of the biker film are also given the majority of story action and character development, as is the case in the Right cycle films. It is true that there are some female-oriented biker films, which I will discuss in the last section of the chapter.

The collective behaviour of the male characters is epitomised by the gang patches worn by most male biker characters. These patches seem to function as a symbol of masculine aggression. Some examples include Run Angel Run!, where Angel wears a patch saying "Devil's Advocates," and also the bikers in Hell's Bloody Devils, who wear a patch reading "Bloody Devils." One biker wears a patch saying "Mad Caps" in Angels from Hell which is accompanied by a skull and wings logo. The gang in Satan's Sadists wear a patch saying "Satans," while in Rebel Rousers the bikers' patch is a red logo reading "Rebel Rousers." These patches signify exaggerated masculinity through the references to death, violence, and the occult. It has been argued that the Hell's Angels' utilization of a patch system is similar to that of military medals, and although "[t]he meaning of each patch is not publicly known [it] identifies each member's specifications or beliefs." ${ }^{381}$ In terms of the onscreen bikers, they generally live up to their patched identities, as rebels, hellraisers and figures of fascism and violence.

Biker film critics argue that there is an "[e]xtremely low esteem of women" and a "demeaning treatment of women" in the biker film. ${ }^{382}$ Bill Osgerby contends

\footnotetext{
${ }^{381} \mathrm{http} / / / \mathrm{www}$. freeonlineresearchpapers.com/hells-angels-organized-crime

382 Rubin, M. "Make Love Make War: Cultural Confusion and the Biker Film Cycle." Film History. Vol. 6, No. 3. (Autumn 1994.) 366.
} 
that as a consequence of the focus on male activity, "biker movies invariably marginalized women, consigning them to the pillion seat as submissive 'old ladies' or sexually compliant "mamas." "383 Although women are not perhaps completely marginalized in the biker film as they are in most Right cycle films, they are nonetheless represented as inferior, dispensable, and as mere 'objects.' This is despite the amount of screen time dedicated to bikers riding around on their motorcycles with their female partners sitting behind them. The 'mamas' are just one group of women in the biker film who are objectified and, in some cases, victimised. As discussed in the previous chapter, female characters in the biker film are often victims of male predatory sexual violence. As such, these films have sometimes been labelled as "misogynistic" due to their "casual regularity" in which they deal with the issue of rape, female molestation and sexual violence. This type of violence is arguably constructed as an erotic spectacle. ${ }^{384}$ These sequences exhibit male dominance over women and seem to epitomise masculinity in these films. More than any other type of abuse found in these films, the female characters are subjected to sexual violence.

In several biker films female characters act as mere 'objects' to the maledominant action onscreen, and are deemed the bikers' property on occasions. For example, a woman is auctioned off for only twenty-six cents in The Savage Seven, and another for a pack of cigarettes in Hell's Angels ' $69 .{ }^{385}$ In another example, a woman has the words 'Property of the Angels' tattooed on her backside in Naked Angels. ${ }^{386}$ In some instances, they are 'passed around' and exchanged between bikers, as well as being taunted, threatened and abused (both verbally and physically) by the bikers' male machismo. These scenes emphasise masculine power over women and its expression in sexual behaviour. Female characters function as sexual exchange objects in a number of biker films. In The Savage Seven the bikers enter the rural town's bar in an early scene, and one finds himself "a little Indian maid”. Lead biker Kisum tells his comrade to "Keep her, we'll pass her around." In a later scene Kisum walks

${ }^{383}$ Osgerby, B. 'Sleazy Riders; Exploitation, 'Otherness,' and Transgression in the 1960s Biker Movie." Journal of Popular Film and Television. Vol. 31, No. 3. (Fall 2003.) 106.

384 Ibid.

385 Rubin, M., 367.

386 Ibid. 
back to the biker camp after being rejected by Maria. A girl tries to seduce him. He responds by ripping her shirt and pushing her away to the other bikers. In another scene a Native American and a biker squabble over a Native American girl, and decide to run a gauntlet to try to 'win' the girl.

Women also appear as potential sexual exchange objects in Angel Unchained. At one point Shotgun tries to swap his partner Jackie for Angel's girl Merilee. After looking at Merilee, Shotgun says, "That's heaven...I can get behind that." In a later scene, Shotgun reiterates his desire for Merilee by asking Angel, “How much do you want for her?” Angel replies, “I don't deal anymore.” In Hell's Belles, Cathy tells Dan that once she was accused to cheating on her man (biker leader Tampa), and that she was subsequently "thrown to the wolves - up for grabs, anyone, anytime." In Run Angel Run!, the hobo on the train tells Angel he wants "to share" Angel's girl Laurie. During one bar scene in Wild Wheels that turns into a drunken orgy, one biker shouts out "Any new broad...everybody gets seconds!"

Physical violence and abuse towards women, whether actual or just threatened, is another important element of masculinity in the biker film. Female characters in the biker films sometimes find themselves victims of the physical brutality that characterises their male counterparts. For example, this occurs in Satan's Sadists when Anchor's gang the Satans enter a camp where two women are staying. The gang members soon begin intimidating the women, then start force-feeding them. Eventually the women are drugged and killed by Anchor. In Wild Wheels Sissy - a girl who is taken away into the night by burly biker Bloomer - reappears and is found to have her clothes torn and some broken ribs after apparently being beaten by him. In Chrome and Hot Leather the antagonistic biker Casey often abuses his partner Susan. In one scene, he slaps her after she shows affection towards soldier-in-disguise biker Mitch. Later on, after Casey finds out that Susan has seduced Mitch, he continually and viciously slaps her round the face for her disloyalty. In Angels Hard as They Come when the Dragons biker gang attacks the hippie population of the ghost town their leader 'the General' slaps a hippie girl, ripping her shirt and exposing her 
breasts before tying her up. She is about to be burnt or perhaps branded by the General but the protagonist biker Long John arrives in time to rescue her.

There are also sequences in which these women are victims of verbal abuse and are treated with a general disregard by their male dominators. The female characters seem to be reduced to 'objects' in these scenes. For example, in a campfire scene in The Savage Seven, one biker chastises another for throwing up on his woman - "You just barfed on my broad!" The girl tries to respond, but is quickly told to "Shut up" by the man. At one point in Hell's Belles Dan refers to Cathy as the bikers' “merchandise." In Satan's Sadists, Anchor has absolutely no respect for his girlfriend Gina. After the Satans terrorize some women in their camp, Gina wants to leave but Anchor refuses to allow this and begins force-feeding her, as he did with the women he killed. He throws her to the ground saying: "I'll replace you...dumb bitch." While Gina still loves Anchor despite his brutality, she means nothing to him. Indeed, he rejects her entirely in a later scene, saying that she is nothing more than a piece of "dead meat."

\section{Some Broader Implications}

We can interpret this kind of behaviour by looking at the work of Claude LéviStrauss. Lévi-Strauss analyses the exchange of women through his study of kinship in the realm of structural anthropology. Lévi-Strauss's argument is that female exchange in many traditional societies indicates that women were treated as sexual objects and as property. ${ }^{387}$ In her analysis of Lévi-Strauss, Gayle Rubin asserts that he "constructs an implicit theory of sex oppression" through his argument that "the essence of kinship systems... lie in an exchange of women between men." ${ }^{388}$ In a similar reading, Bob Scholte argues that for Lévi-Strauss "kinship systems are alliances between groups to ensure the exchange of women, and economic systems to allow the exchange of material

\footnotetext{
${ }^{387}$ Lévi-Strauss, C. Structural Anthropology. New York and London: Basic Books, 1963. 59-61; 83.

${ }^{388}$ Rubin, G. "The Traffic in Women: Notes on the 'Political Economy' of Sex." Nicholson, L. (ed.) The Second Wave: A Reader in Feminist Theory. New York and London: Routledge, 1997. 35 .
} 
goods." ${ }^{389}$ Lévi-Strauss develops his ideas about kinship in a structuralist context. He merges two different ideas: one revolves around Mauss's argument on the role of gift giving, and the other is the incest taboo. ${ }^{390}$ Lévi-Strauss's dual articulation of both the "gift" and the incest taboo enable him to formulate the view that women function as exchange objects. ${ }^{391}$

In terms of gift exchange, marriages are a basic example of this, "in which it is the women who are the most precious of gifts." 392 Gayle Rubin asserts that Mauss's analysis of gift exchange has two functions: one is that the giving of gifts "confers upon its participants a special relationship of trust, solidarity, and mutual aid" whereas the other sees gift exchanges as the idiom of both competition and rivalry. ${ }^{393}$ The incest taboo, meanwhile, is most widely recognized as being a mechanism to ensure that gift exchanges occur between families and groups. This also "imposes the social aim of exogamy and alliance upon the biological events of sex and procreation." $" 394$ The results of this shows that men, in this respect, have power and control over women: "The result of a gift of women is more profound than the result of other gift transactions, because the relationship thus established is not one of reciprocity, but one of kinship." 395 As I have already argued, this type of exchange is also found in the biker film. These exchanges facilitate male bonding between bikers and can arguably be read in homoerotic terms.

As I have already argued, one way in which the homosocial or male centred qualities of the biker film is expressed through gang patches. The fascist iconography which pervades these films can also be interpreted in similar terms. The biker films often use German and Nazi insignia including swastikas, iron crosses, Luftwaffe aviation wings, and Pickelhaube helmets. Klaus Theweleit's study on the fascist German Freikorps that were active between the World Wars

${ }^{389}$ Scholte, B. "Epistemic Paradigms: Some Problems in Cross-Cultural Research on Social Anthropology History and Theory." Hayes, E.N. and Hayes, T. (eds.) Claude Lévi-Strauss: The Anthropologist as Hero. Cambridge, Massachusetts and London: The M.I.T. Press, 1970. 110.

${ }^{390}$ Lévi-Strauss, 46.

${ }^{391}$ Rubin, G., 35.

${ }^{392}$ Ibid., 36.

${ }^{393}$ Ibid., 35-36.

394 Ibid., 36.

395 Ibid. 
is important in terms of analysing the use of such iconography in biker films. Theweleit's Male Fantasies "is primarily concerned with the ways in which the soldierly men defined the boundaries of their own bodies and therefore the visible edges of their own masculinity through a symbolic ordering of the women with whom they came into contact and conflict." ${ }^{396}$ Put simply, Theweleit presents a study of how these fascist soldiers had a profound fear of women, and what these women further represented and symbolised to the insecure gendering of these soldierly men. To the Freikorps, "women became embodied symbols of male anxieties about the porous and disintegrating boundaries of both their own bodies and the state with which they identified themselves, Germany." ${ }^{397}$ The Freikorps themselves were unable to express love towards women and incapable of experiencing intimacy with them. ${ }^{398}$ These military men were fearful of the sexuality of women "both because it disgusts them and because they cannot cope with the intense feelings it arouses in them." ${ }^{399}$ They did, however, feel passionately about men and masculine causes, thereby suggesting a homosocial or even homosexual tendency. ${ }^{400}$

The Freikorps separated women into two categories, the 'White' woman and the 'Red' woman. 'White' women were generally considered nonthreatening, and included such virtuous female figures such as mothers, sisters, and white nurses. ${ }^{401}$ 'Red' women, however, were deemed to be erotic, immoral and carried the threat of castration. ${ }^{402}$ As Theweleit argues, "Women who don't conform to any of the 'good woman' images are automatically seen as prostitutes, as the vehicles of 'urges'. They are evil and out to castrate, and they are treated accordingly." 403 The Freikorps' reactions to 'Red' women formed the basis of their hostility towards women. The Freikorps' main goal was to

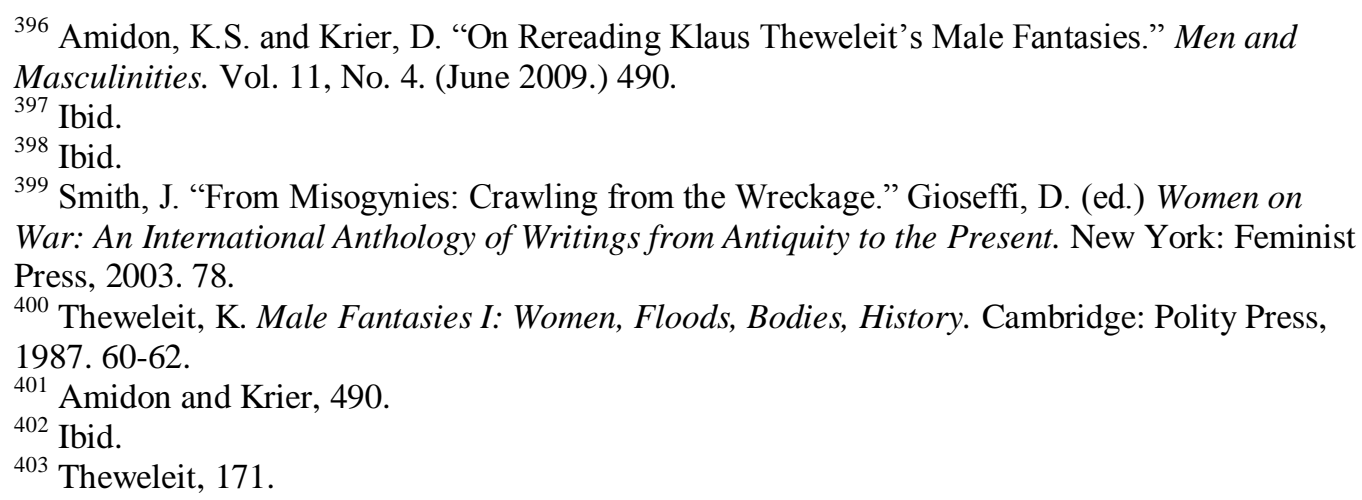


murder and "annihilate" them, ${ }^{404}$ by beating and shooting them into a "bloody pulp. $" 405$ Thus, the sexually-threatened soldier who attacks and destroys the threat posed by women plays an important part in the hypermasculine behaviour of the Freikorps. Theweleit's research can be applied to the biker film because of the way male bikers behave and these films' use of fascist iconography. In this respect, the rise of second wave feminism in the late 1960s is interesting. For example, Karen Boyle claims that due to the rise in women's liberation movements during this period "the focus on relationships between men...was read as a symbolic annihilation of women."

Fascist symbols and insignia are common in the biker film. Hell's Bloody Devils contains a large number of examples of Nazi Germany war insignia. For example, one biker has swastika bands wrapped around his leg and his arm, and wears a small German Iron Cross on the front of his jacket. There is also a large swastika flag hanging behind the main antagonist Count von Delberg in a room in which a Nazi war film is being shown. After the screening the audience give a fascist salute. Angels from Hell features an old man sitting outside a bar wearing a German Iron Cross around his neck. The character Nutty exchanges an Iron cross with a hippie girl, who in return gives him some counterculture paraphernalia. In Satan's Sadists an Iron Cross is featured on the back of the bikers' patch, and lead biker Anchor has a large white swastika on his jacket, as well as an Iron Cross hanging from his neck. In Run Angel Run! there is an Iron Cross on the back of Angel's bike and another small one on the back of his jacket. In the drunken bar scene in Run Angel Run! a small Luftwaffe symbol and an Iron Cross feature on the back of another biker's jacket. These symbols appear to have a dual role in the narratives: they signify an overt masculine presence but also act as anti-establishment symbols of rebellion. Theweleit's research on the links between masculinity and fascism suggests that the fascist iconography in biker films is another symptom of male hostility towards women.

\section{The Revisionist Western}

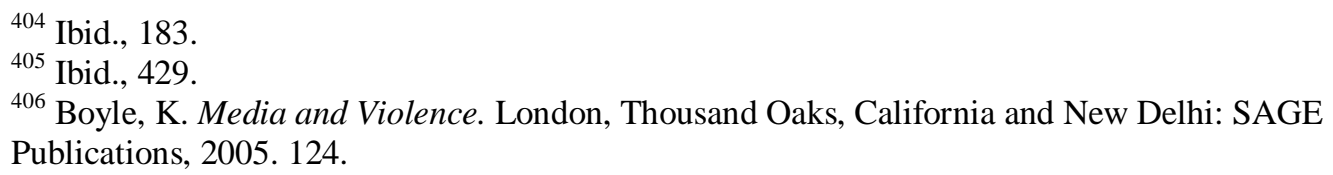


As this chapter has shown, associations can be made between the biker film and the Right cycle films of the late 1960s and early 1970s through the themes of masculine physical and sexual violence. However, it is also important to explore whether these trends are identifiable in other genres in an attempt to continue mapping a relationship between the biker film and other genres. The Western is another genre that can be associated with the biker film. This section will concentrate on the revisionist Western, which includes the European Spaghetti Westerns and American Westerns made between about 1968 and 1975, because this group of films was made during a similar period to the biker and right cycle films. The Western is of course a vast and broad genre, so this section of the chapter will pay attention to the links made through the issues of gender and violence.

Robert Ray argues that both the Right and Left cycle films can be interpreted as "disguised" Westerns: "The Right movies...were urban westerns, briefs for the continued applicability of the reluctant hero story to contemporary life. ${ }^{, 407} \mathrm{He}$ claims that "the Right movies reduced enormous social issues (war, crime, urbanization) to localized emergencies solvable by simple, direct action involving no long-term commitment to reform." ${ }^{408}$ Right cycle films such as Dirty Harry and Death Wish appear to bear the traits of a "reluctant heroes" involved in "direct action." 409 The violent confrontations in these films resemble the shootouts of the Western genre. One example of this is at the end of Dirty Harry, in which Harry and Scorpio exchange gunfire during the final chase sequence through an industrial factory.

One reason that Right cycle films can be construed as "disguised Westerns" is that their characters have similar character traits to those found in Westerns. As Ray argues, "In the Right's view, difficulties required only an individual hero strong enough to stand up to the villain for the sake of ineffective communities." ${ }^{410}$ Lev also asserts that "Dirty Harry affirms individual

\footnotetext{
${ }^{407}$ Ray, 307.

408 Ibid.

409 Ibid.

${ }^{410}$ Ibid.
} 
heroism." 411 The Western often features a solitary cowboy hero who helps confirm the genre's status as a male-oriented one. "The Western revolves around the lone cowboy riding the range, bringing justice and civilisation to the frontier with a maximum of male heroics." 412 John Saunders claims that the Western hero: "the outlaw represents an extreme instance of the individualism that is central to the myth of the West."

Susan Hayward argues that many 1960s Western heroes were "motivated by revenge," without any "visible reason or moral point of view that explained this motivation." ${ }^{414}$ Leone's Spaghetti Westerns contain a range of lawless figures: "there are no cowboys in Leone's West, only bounty hunters, bandits and drifters. ${ }^{415}$ Lev, meanwhile, contends Right cycle characters and the figures that feature in Leone's Westerns are connected by their lack of emotion and amorality: "Kersey in Death Wish...maintains an unfeeling impassivity from the death of his wife through the rest of the movie. He has a tiny range of emotion: bleak smile, uncaring stare. This impassivity, like Eastwood's cool nonchalance, may derive from the films of Sergio Leone."416

Biker film critics have also claimed that the biker film is intertextual and that the biker film often intersects with the revisionist Western. Perlman and Syder give the most detailed analysis of the Western's associations with the biker film. Syder asserts that " $\mathrm{t}]$ he most common generic template [of the biker film] was that of the western," because the majority of biker films drew parallels between biker gangs and the Old West. ${ }^{417}$ Allison Perlman argues that biker films are "updated westerns," and calls them "an extension of the western," as well as

\footnotetext{
${ }^{411}$ Lev, 35.

412 Benshoff and Griffin, 251.

${ }^{413}$ Saunders, J. The Western Genre: From Lordsburg to Big Whiskey. London: Wallflower, 2001. 64.

${ }^{414}$ Hayward, S. Cinema Studies: The Key Concepts. London and New York: Routledge, 2000. 473.

${ }^{415}$ Kitses, J. Horizons West: Directing the Western from John Ford to Clint Eastwood. London: BFI Publishing, 2004. 255.

${ }^{416}$ Lev, 38-39.

417 Syder, A. "Ripped from Today's Headlines: The Outlaw Biker Movie Cycle.” December 2002. [online journal]. http://www.scope.nottingham.ac.uk/article.php?issue=dec2002\&id=271\&section=article
} 
"westerns on wheels." ${ }^{418}$ Osgerby also refers to the biker films as "iron horse' epics." ${ }^{419}$ Similarly, John Cawelti calls the biker films "post-Westerns," and claims that they "borrow the symbols, tropes, and narrative concerns of the Westerns but situate them in a new setting and context."420

Perlman sees the biker as a "modern day cowboy," riding around on his mechanical steed in the same way that a Western hero would journey through the American wilderness on his horse. ${ }^{421}$ While " $[\mathrm{t}]$ he Western traverses the barren wilderness," Perlman argues, "[t]he terrain of the biker films is the mechanized highway." 422 Similarly, Osgerby contends that "the frontier pioneer is constructed as a rugged individualist - sturdy, autonomous, and resourceful. A core theme in the imagery and narratives of the Western, this mythology of individualism was reclaimed in the 1960s biker genre." ${ }^{423}$ Perlman also maintains that biker films take place in the environment of the Western, but only after the figures of the Western have already moved on, or have passed into history. "[T]he biker movies examine what happens after the Westerner has established law and order and paved the way for civilisation to flourish." 424 The bikers, in this respect, appear to destroy any civilised law and order established by the Western heroes with their marauding and violent behaviour.

It could be argued that characters in biker films such as Heavenly Blues in The Wild Angels, Pilot in Angel Unchained, and Kisum in The Savage Seven also possess the same kind of "cool nonchalance" as Eastwood's famous "Man with No Name' character in Leone's Westerns. As Syder argues, the biker films contained characters who were "sadistic, despicable and villainous," such as Anchor and his biker gang in Satan's Sadists, and therefore can be argued as

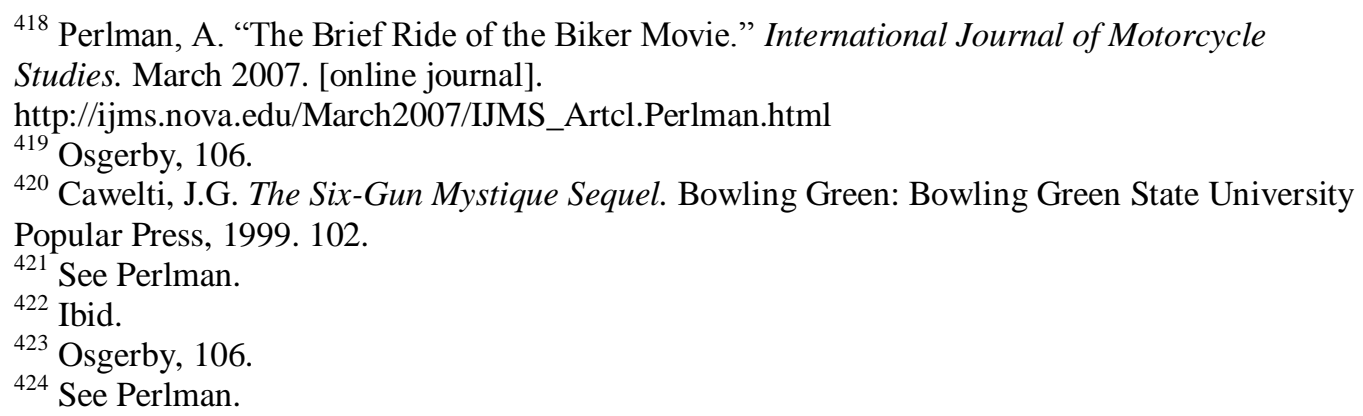


possessing the same kind of "antiheroic, antiestablishment traits that made outlaws so popular in the Westerns of the late 60 s. $" 425$

Although there are some Westerns in this period with prominent female characters, Günsberg argues that femininity was constructed primarily around sexuality, especially in Leone's Spaghetti Westerns. ${ }^{426}$ "'[F]emininity is usually represented exclusively through sexuality, often directly through prostitution." ${ }^{427}$ Christopher Frayling claims that women in Spaghetti Westerns only appeared rarely and when they did appear, they were usually madonnas and whores. ${ }^{428}$ Similarly, Rachael Langford argues that "women are absent or ejected as agents from the filmic universe, but present in objectified form as things to be protected, directed and dominated, albeit often paternalistically."429 For example, female characters in the Dollars trilogy are depicted as either prisoners due to sexual lust and jealousy, such as Marisol in A Fistful of Dollars (1964), or as the murder victims of vicious bandits, as in For A Few Dollars More (1965). In the latter film, there is a scene in which bandit and recently escaped prisoner El Indio does not think twice about ordering the murder of a woman and her baby, and actually seems to enjoy the experience. Frayling, meanwhile, recalls one of his female students likening The Good, The Bad and the Ugly (1966) to "being at a football match where all the men stare at each other", rightly suggesting that female characters in this film have been sidelined completely, except for only appearing as bit-parts and victims of male violence. ${ }^{430}$ It is also interesting that in the opening scene of High Plains Drifter (1973), a film that is clearly influenced by Spaghetti Westerns, Eastwood's character viciously rapes a woman and leaves her distraught and defenceless. She, too, is a victim of brutal masculine force that is also pervasive in the biker film.

\footnotetext{
425 See Syder.

${ }^{426}$ Günsberg, M. Italian Cinema: Gender and Genre. Houndmills, Basingstoke, Hampshire and New York: Palgrave Macmillan, 2005. 173.

${ }^{427}$ Ibid.

${ }^{428}$ Frayling, C. Spaghetti Westerns: Cowboys and Europeans from Karl May to Sergio Leone. London and New York: I.B. Tauris, 2006. xvi.

${ }^{429}$ Langford, 79.

${ }^{430}$ Frayling, xvi.
} 
The Western and the biker film can also be linked through their use of physical locations. In terms of the Spaghetti Western, Kitses argues that Leone's rural landscapes are particularly hostile terrain containing violent inhabitants. $\mathrm{He}$ describes these spaces as "a vacant environment for characters who are equally empty." 431 As previously discussed, many biker films take place in the desert and rural towns, notably The Savage Seven, which places a majority of its onscreen action around a small desert town. Angels Hard as They Come is also set largely in a desert ghost town. Hell's Belles and The Mini-Skirt Mob both take place amongst rocky and desert terrain, while Chrome and Hot Leather uses a desert and canyon landscape as its setting.

\section{Clint Eastwood}

Clint Eastwood is a significant figure in establishing the lineage of the modern action film and its emphasis on violent spectacle. For example, Eastwood plays an important role in the transition from the Western to the action film via the Right cycle films. In terms of the Spaghetti Westerns, Günsberg claims that " $[t]$ he iconography and major characteristics of masculinity in the genre were established by Clint Eastwood."

In the sphere of masculine heroism, in fact, it is difficult to see how we could have gotten from Wayne to Schwarzenegger except by going through Eastwood. The larger-than-life classical heroism of Wayne gives way to the transcendentalism and covert impossibility of the Eastwood persona; this in turn is followed by the frank comic-book exaggerations of Schwarzenegger's musculature and in some way overt impossibility of his persona. $^{433}$

Films such as Dirty Harry and the Sergio Leone westerns all featured Clint Eastwood as the protagonist as The Man with No Name or as Harry Callahan respectively. A key film in this transition is Coogan's Bluff. Here Eastwood's Arizona sheriff character is displaced from his natural, rural Western environment to the urban decay of New York City. This can be viewed as a crossover from the rural landscape that hosts The Man with No Name in the

\footnotetext{
${ }^{431}$ Kitses, 258.

432 Günsberg, 174.

${ }^{433}$ Beard, 11.
} 
urbanised vistas of the city, a setting that accommodates Harry Callahan. Coogan's costume also noticeably includes a cowboy hat, boots and a bolo tie.

Harry Callahan and the Man with No Name can both be associated with the biker film characters through the issues of masculinity and violence. Ray argues, "To the role of the tough cop Harry, Clint Eastwood brought his associations with western heroes, particularly those from the Sergio Leone Italian westerns where he had played... a relentless, silent, efficient gunfighter, who merely happened to be on society's side." ${ }^{434}$ Similarly, Lev claims that the characters of Dirty Harry and The Man with No Name are associated with each other through their "mythic" and "superhero" characteristics. ${ }^{435}$ He describes Eastwood's Western gunslinger as a "good-bad guy with an amoral, nihilistic streak." Beard suggests that these two figures are linked by their "domination through violence. ${ }^{437}$ He contends that:

no classical western ever permitted its hero such a naked display of violent dominance as Leone's films or the 'cowboy cop' Harry Callahan exhibit...Both these characters...need ultimately to affirm their mastery, their power, in the bluntest possible existential terms - by taking the lives of others in combat situations. ${ }^{438}$

Paul Smith maintains that, in terms of the representations of violence, Dirty Harry "exceeded by far the conventions of cinematic verisimilitude at the time." ${ }^{439}$ It is through Eastwood's "absolute mastery of violence" that masculinity can, once again, be identified, and which can also be linked to Eastwood's screen persona. ${ }^{440}$

Beard argues that Eastwood's persona "represents probably the single strongest icon of heroic masculinity in popular cinema over the past quarter-century." Clint Eastwood's early films are thus significant for this thesis because the

\footnotetext{
${ }^{434}$ Ray, 308.

${ }^{435}$ Lev, 35.

436 Ibid.

${ }^{437}$ Beard, 18.

${ }^{438}$ Ibid.

${ }^{439}$ Smith, P., 94.

${ }^{440}$ Beard, 1.

${ }^{441}$ Ibid., ix.
} 
socio-political dimension has often been criticised. Pauline Kael famously argued that, "'Dirty Harry is obviously just a genre movie, but this action genre has always had a fascist potential, and it has finally surfaced." ${ }^{442}$ Martin Flanagan also sees Eastwood as being a "borderline fascist hero." ${ }^{, 43}$ Paul Smith contends that one can use, albeit cautiously, the term 'fascist' in relation to Eastwood films such as Dirty Harry "insofar as this fantasized ideal of the white male father who ruthlessly ensures security and carries out the right kind of vengeance on behalf of the community, on 'our' behalf, directly addresses the kind of psychological structures that have been associated with the fascist subject." ${ }^{444}$ Similarly, Lev regards the character of Callahan as embodying and adding a tough, unyielding amorality and nihilistic streak to the films in which he features. He claims that Callahan "believes in nothing, certainly not in law or government; nothing except his own limited ability to right some wrongs," and he "presents an impassive, unfeeling, misanthropic face to the world." $" 446$ As I have argued previously, these 'fascist' and amoral qualities are also found in the biker films. This reinforces the view that the biker film should be situated within a continuum of conservative leaning genre films that stretches from the 1960s revisionist Western through to contemporary action films.

\section{The Action Film}

This chapter will now deal with the action film, specifically the films of the 1980s and 1990s. Two facets of the action film in this period are important for our purposes here: visually exciting action sequences and the visual fascination with the masculine body. In terms of action sequences, there is a strong focus in actions films on explosions, violent and bloody gunfights and chase scenes, as well as special effects and computer generated imagery (CGI). Films such as Aliens (1986) and Die Hard (1988) have numerous scenes of spectacle featuring explosive action, gunfights and exciting chase sequences. Terminator 2:

Judgement Day (1991) and Independence Day (1996) are examples of action films that contain special effects and CGI. In Terminator 2 the renowned liquid

\footnotetext{
${ }^{442}$ Kael - quoted in Kass, J.M. Don Siegel. London: Tantivy, 1975. 147; also quoted in Smith, P., 90.

${ }^{443}$ Flanagan, 112.

${ }^{444}$ Smith, P., 94.

${ }^{445}$ Lev, 34.

${ }^{446}$ Ibid., 38.
} 
metamorphosis of the antagonistic T-1000 was achieved by CGI. Throughout Independence Day there are computer-generated scenes of alien invasions and the destruction of various American landmarks such as the White House. These visually stimulating action sequences are important because the biker film also has many scenes designed to have a broadly similar impact on the audience. However, as a low-budget genre the biker film features low-tech mayhem, focusing its resources instead on brawling violence and vehicle stunts.

As both Tania Modleski and Fred Pfeil argue, much of the spectacle in contemporary action films involves violence of some kind, especially male violence. "Through spectacle (bombs bursting in air) and sound (usually heavy rock), pro-war fantasies like Top Gun (1986) mobilize the kind of aggression essential to the functioning of men as killing machines." ${ }^{447}$ Pfeil claims that both Rambo: First Blood Part II (1985) and Top Gun feature "male violence and / or death-trip spectacle again and again." ${ }^{448}$ Given this, it is perhaps unsurprising that women are often marginalised in action films in the 1980s. Tasker argues that in a general sense "[w]hilst the woman in the action narrative may operate as some kind of symbolic guarantee, a place for the fixing of difference and heterosexual desire, she is simultaneously rendered increasingly marginal. ${ }^{449}$ In extreme versions of this marginalisation women were written out of the narrative altogether, such as in films like First Blood (1982). ${ }^{450}$ However, as this chapter will go on to discuss, there were prominent female roles in this genre in the 1980s and 1990s, such as Ellen Ripley in Aliens and Sarah Connor in The Terminator (1984) and Terminator 2: Judgement Day. ${ }^{451}$

The 1980s action film also emphasised the role of the 'male hard body' as an embodiment of masculinity and simultaneously as spectacle. ${ }^{452}$ Neale argues that there is a particular focus on the "hyperbolic bodies" of action stars such as

\footnotetext{
${ }^{447}$ Modleski, T. “A Rose Is a Rose? Real Women and a Lost War.” Lewis, J. (ed.) The New American Cinema. Durham, NC: Duke University Press, 1998. 125.

${ }^{448}$ Pfeil, F. "From Pillar to Postmodern: Race, Class, and Gender in the Male Rampage Film." Lewis, J. (ed.) The New American Cinema. Durham, NC: Duke University Press, 1998. 172.

${ }^{449}$ Tasker, Y. Spectacular Bodies: Gender, Genre and the Action Cinema. London and New York: Routledge, 1993. 16.

450 Ibid.

${ }^{451}$ Ibid., 146-150.

${ }^{452}$ Ibid., 2.
} 
Arnold Schwarzenegger, Sylvester Stallone and Bruce Willis. ${ }^{453}$ Susan Jeffords concurs that the male body of the action film often became "the most fulfilling form of spectacle." ${ }^{454}$ This was achieved through the extreme muscular definition of the actors' bodies, which offered an objectification that was usually reserved for the female body. In other words, the body in the action film was spectacular due to its "sheer physical excess." 455 Jeffords contends that the action male's body “became increasingly a vehicle of display - of musculature, of beauty, of physical feats, and of a gritty toughness." 456 The visible excess of this muscular male action body contributes to the hypermasculinity of these films.

Hypermasculinity perhaps takes it most extreme and potent form in the action film. The central characters used their enhanced physiques to solve problems, resolve conflicts and dominate other men. Barbara Creed goes so far as to claim that these muscular characters embody the ultimate representation of masculinity, the phallus. "Both [Stallone and Schwarzenegger] often resemble an anthropomorphised phallus, a phallus with muscles... They are simulacra of an exaggerated masculinity. ${ }^{, 457}$ An association can be made between Eastwood's Man with No Name and the heroes of the action film, as both types of character ultimately present a persona of invincibility and hypermasculinity. "[M]ovie stars like Arnold Schwarzenegger, Jean-Claude Van Damme, and Sylvester Stallone were demonstrating that hypermasculine men could withstand any attack and still save the day, often single-handedly." 458 Eastwood demonstrated similar prowess in the Dollars trilogy, Dirty Harry and High Plains Drifter. By concentrating on the "sheer physical excess of the muscular

\footnotetext{
${ }^{453}$ Neale, S. "Action-Adventure as Hollywood Genre." Tasker, Y. (ed.) Action and Adventure Cinema. London and New York: Routledge, 2004. 71.

${ }^{454}$ Jeffords, S. "Can Masculinity Be Terminated?” Cohan, S. and Rae Hark, I. (eds.) Screening the Male: Exploring Masculinities in Hollywood Cinema. London and New York: Routledge, 1993. 245.

${ }^{455}$ Tasker, Y. "Dumb Movies For Dumb People: Masculinity, the Body, and the Voice in Contemporary Action Cinema." Cohan, S. and Rae Hark, I. (eds.) Screening the Male: Exploring Masculinities in Hollywood Cinema. London and New York: Routledge, 1993. 232. 456 Jeffords, 245.

${ }^{457}$ Creed, B. "From Here to Modernity - Feminism and Postmodernism." Screen. Vol. 28, No. 2 (1987), 65; see also Tasker, Screening the Male, 232.

${ }^{458}$ Benshoff and Griffin, 278.
} 
stars, ${ }^{, 459}$ this image of masculinity is ultimately one of hysteria, a masculinity out of control.

This exaggerated masculinity provides another link between the Western, the Right film, and the biker film. The biker film often shows the male body in terms of bulging muscular arms and torsos, even though they may not match the size or muscle capacity of action stars such as Schwarzenegger and Stallone. The presence of muscular, burly bikers is evident in characters such as Nutty in Angels from Hell, Gippo in Hell's Belles, Bloomer in Wild Wheels, and Bull in The Savage Seven. A particularly hairy biker features at the beginning of Angels Hard as They Come. He steals a riot-control device, and wears a sleeveless jacket that allows him to exhibit his large arms. William Smith, who plays Angel in Run Angel Run! and T.J. in Chrome and Hot Leather (amongst other biker roles), is often shown baring his muscles in the biker films he appears in. In Run Angel Run! for example, he wears a sleeveless denim jacket which shows off his huge biceps. The opening scene of this film shows Smith riding along a road, with his arm muscles tensed up and bulging. Interestingly, Smith was a real life winner of both arm-wrestling and weightlifting championships action films have often used former martial arts champions either as protagonists or villains.

The Western and the Right cycle film arguably anticipate the action film of the 1980s and beyond through their mutual emphasis on masculinity and violent spectacle. Geoff King argues that action films are ultimately updated Westerns. This is particularly evident in characterisation: "the action heroes are individuals with at least some characteristics that can be linked to those of the mythical 'frontier' tradition, carefully positioned outside the mainstream of bureaucratic institutions but also distinguished from contemporary versions of the 'savage' existing beyond the pale." ${ }^{\text {460 }}$ Flanagan reiterates King's argument but extends it to the heroes of the Right cycle film, claiming that "John Wayne, a figure whose connotations of masculinity seem 'absolutely fixed', is an iconic

${ }^{459}$ Tasker, Screening the Male, 232.

${ }^{460}$ King, G. Spectacular Narratives: Hollywood in the Age of the Blockbuster. London and New York: I.B. Tauris, 2000. 111. 
precursor of the action star, while the borderline fascist heroes played by Clint Eastwood and Charles Bronson...can also be included."461

\section{The Female Biker Film}

This chapter has argued that the biker film is generally considered to be a malefocused genre, focusing specifically on masculine issues. As has been discussed, the role of women in the conventional male-focused biker film is often as incidental girlfriends and 'mamas,' as well as being exploitable victims of physical or sexual violence. ${ }^{462}$ As Perlman writes, "If they are not silently standing by their men, they are cavorting half-naked at one of their parties."463 However, this is not always the case. There are some biker films that focus on female biker gangs and feature female biker characters prominently, usually in films "when the macho creed of the biker was less than monolithic." ${ }^{464}$ Films which concentrate on female bikers include The Mini-Skirt Mob, The Hellcats, Angels' Wild Women, Sisters in Leather (1969) and She-Devils on Wheels (1968). The female protagonists in these films generally have the same type of role as male bikers in the male-oriented biker film, and can also be seen as intimidating, violent, aggressive and vengeful figures. For example, in SheDevils on Wheels the women are sadistic and they terrorise the male characters by selecting "their sexual playthings from a 'stud line,' later dragging the discarded lover behind their speeding motorcycles." "465 In Angels' Wild Women, one male character is the victim of a gang rape by a group of biker women. ${ }^{466}$ Osgerby argues that this is a "construction of a predatory and sexually demanding femininity." ${ }^{467}$ Although there are only a few female centred biker films they are nonetheless important to the relationship between gender and genre in the action film. However, apart from occasional observations, biker film critics have mostly neglected the significance of these films.

${ }^{461}$ Flanagan, M. "'Get Ready for Rush Hour': The Chronotope in Action.” Tasker, Y. (ed.) Action and Adventure Cinema. London and New York: Routledge, 2004. 112; see also Tasker, Screening the Male, 234.

462 See Perlman.

463 Ibid.

464 Osgerby, 106.

465 Ibid.

466 Ibid.

${ }^{467}$ Ibid. 
In this respect, the female biker film could be regarded as a prototype of the female action film. The female action film often contains female characters who are dominant, violent and strong. As Neroni claims of such films, "[r]ather than waiting for men to protect them, female characters have begun to protect themselves." 468 Some examples include the titular characters in Thelma \& Louise (1991), Ellen Ripley in Alien (1979), Sarah Connor in Terminator 2: Judgement Day, and Charly Baltimore in The Long Kiss Goodnight (1996). It can also be argued that these female characters fit into the category of the 'warrior women. ${ }^{469}$ Barbara Creed argues that the warrior woman "exhibits exceptional bravery and intelligence and is prepared to die for her beliefs," and "comes into direct conflict with male beliefs and values which she sees as inimical to her own ethical position." ${ }^{\text {"41 }}$ Neroni maintains that "[c]ontemporary American films featuring violent women are especially complex and contradictory in terms of gender definitions." 472 What this suggests is that although a female protagonist can be a powerful figure in these films, such a woman is still competing in a masculine world. Thus, the issue of masculinity does not necessarily dissipate just because the focus is on a female character.

Hilary Neroni offers two different ways of reading the similarities and connections between male and female action heroes. The first is that the presence of women is progressive, and a disruptive force in terms of gender conventions and norms. Neroni contends that because these female characters are as violent as they appear, they are thus deemed more threatening because they ultimately break down gender boundaries:

In all arenas of violence - war, domesticity, criminality, law enforcement - it is masculinity that gives violence its meaning. The intertwined nature of violence and masculinity is one of the reasons the violent woman is so

\footnotetext{
${ }^{468}$ Neroni, 15 .

${ }^{469}$ Creed, B. "The Neomyth in Film: The Woman Warrior from Joan of Arc to Ellen Ripley." Andris, S and Frederick, U. (eds.) Women Willing to Fight: The Fighting Woman in Film. Newcastle: Cambridge Scholars Publishing, 2007. 22.

${ }^{470}$ Ibid.

${ }^{471}$ Ibid.

${ }^{472}$ Neroni, 84.
} 
threatening: she breaks up this symbolic relationship between violence and masculinity. ${ }^{473}$

It can be argued that the breakdown of gender boundaries is also what makes some female bikers - such as Shayne in The Mini-Skirt Mob - appear so powerful and threatening. It is also important to refer to these female-oriented action and biker films because they represent a distinct break in the norms of these genres in terms of gender. While not appearing particularly unconventional, both genres in this respect represent an “'inversion' of power relations," ${ }^{474}$ which is another way in which these genres may be linked. The same correlation can be found in the female biker gangs of The Hellcats and She-Devils on Wheels.

However, this transgressiveness and role-reversal has its limits. Neroni argues that although the female action film contains strong women embroiled in violence, the violence onscreen cannot be separated from its masculine connotations. This is because Neroni regards violence as the central characteristic that defines masculinity in the cultural imagination. ${ }^{475}$ Instead of representing a significant example of femininity, these heroines and their violent actions can still be viewed as masculine. "One cannot separate ideas of masculinity from violence in our society - which is why, for example, a woman committing violence is inevitably at some point referred to as masculine." Because female biker characters in this instance resemble the violent male figures that usually pervade these films, they can also be seen as embodying a rigid masculinity, as they also brawl and ride around menacingly. The resolution of these apparent contradictions is outside the scope of this thesis, but clearly there seems to be an opportunity for more (feminist) research on these films.

\section{Conclusion}

The relationship between gender and genre in the biker film has similarities to the Western, the Right cycle films, and the action film. This suggests that in ideological terms these films belong to a continuum of genre-oriented works in

\footnotetext{
473 Ibid., 45-46.

474 Osgerby, 107.

${ }^{475}$ Neroni, 19.

${ }^{476}$ Ibid., 45.
} 
post-war American cinema that presents an exaggerated version of masculinity which is linked to violent behaviour. Chapter three also indicated that biker film narratives can be connected to some narrative features of New Hollywood cinema and subsequent action films. It is now time to draw some conclusions about these links. 


\section{The Aftermath of the Biker Film}

The biker film cycle began to decline from 1971 and production seems to have stopped around 1974. It is difficult to know exactly why this occurred. It may have been due to genre 'exhaustion'. In this respect, it is worth noting that the biker film began to 'mutate' as producers created hybrids with other genres, perhaps losing some of its earlier authenticity. As Martin Rubin argues, In its waning years, the biker film cycle tended to distance itself further and further from the bikers themselves by making them increasingly abstract figures of evil, by camping them up, and by booting them into other generic contexts... as if to acknowledge they no longer merited one of their own. ${ }^{477}$

Some examples include Werewolves on Wheels (1971) (horror), The Black Six (1973) (blaxploitation), and the transvestite biker film The Pink Angels. ${ }^{478}$ Audiences who were interested in other (disreputable) genres such as horror and blaxploitation may have preferred 'pure' examples. As we know, the 1970s was a vibrant period in American cinema for both the horror and blaxploitation film.

After 1974 the biker gang continued to appear occasionally in American films, if only as a reference point. For example, Every Which Way But Loose (1978) and its sequel Any Which Way You Can (1980) feature an inept, clumsy and comic biker gang, the Black Widows, who act as the antagonists of these films. They are frequently left ridiculed and embarrassed after becoming the victims of several of the action set-pieces and stunts across both films. This parodic treatment recalls the way biker characters were represented in the Beach Party films. Peter Fonda's cameo as the 'Chief Biker' leader of a gang in The Cannonball Run (1981) can be read as a parody of both his roles as Heavenly Blues in The Wild Angels and Wyatt in Easy Rider. Later examples include Hell Riders (1984), Stone Cold (1991) and The Stranger (1995), which is a female biker film.

${ }^{477}$ Rubin, M. "Make Love Make War: Cultural Confusion and the Biker Film Cycle." Film History. Vol. 6, No. 3. (Autumn 1994.) 376-377.

${ }^{478}$ Osgerby, B. 'Sleazy Riders; Exploitation, 'Otherness,' and Transgression in the 1960s Biker Movie.” Journal of Popular Film and Television. Vol. 31, No. 3. (Fall 2003.) 107. 
Biker gangs also featured in a number of films produced outside of America in the 1970s and 1980s. In Australia these include Stone (1974), Mad Max (1979) and Mad Max 2 (1981). ${ }^{479}$ Stone has a narrative similar to The Born Losers, in which a lone hero stands up against a biker gang and comes into conflict with them. The character of Stone could therefore been seen to have associations with Billy Jack, the protagonist of The Born Losers. ${ }^{480}$ The Mad Max films feature post-apocalyptic characters who ride motorcycles. They play a particularly important function in the first film in which they function as the main antagonists. They murder Max's wife, son and best friend. He spends much of the film wreaking revenge. The Mad Max films are clearly action films that contain considerable violence and several 'spectacle' scenes, which also links them with the American biker films. ${ }^{481}$

Other non-American examples include Quadrophenia (1979), which might be seen as a British version of the biker film. In this film the bikers featured are the leather-clad and patched Rockers, who become involved in a huge brawl with the Mods on Brighton beach. In this scene the Rockers beat the Mods with sticks. Elsewhere some Rockers are beaten up in a local bar while others get thrown over the seawall by the Mods. ${ }^{482}$ Survival Zone (1983) is a South African post-apocalyptic film featuring violent biker gangs. Hog Wild (1980) is a Canadian teen comedy about a boy who returns home after being expelled from military school to find that his old high school is under threat from a biker gang.

\section{Resurrecting the Biker Film}

The biker film has made a brief comeback in recent years, with the appearance of Wild Hogs (2007) and the television series Sons of Anarchy (2008-). Yet rather than being a sign of a rebirth of the genre, Wild Hogs can arguably be read as being an allegory of the biker film's disappearance. The four central

\footnotetext{
${ }^{479}$ It is notable that Hugh Keays-Byrne plays an antagonistic biker in both Stone and Mad Max. ${ }^{480}$ For more information on The Born Losers see Lott, M.R. The American Martial Arts Film. Jefferson, N.C.: McFarland \& Company, 2004. 33-34; 42-46.

${ }^{481}$ See also Martin, A. The Mad Max Movies. Strawberry Hills, NSW: Currency Press, 2003.

${ }^{482}$ See also Feldman, C.J. "We Are the Mods": A Transitional History of a Youth Subculture. New York: Peter Lang Publishing, 2009.
} 
characters who ride motorcycles in the film are ageing middle-class men with families. They all lead dull but stressful suburban lives. In this respect, the role of the biker figure has transformed from younger working-class bikers to older, middle-class alternatives. In the context of Wild Hogs, the biker figure has now become exactly the type of person his 1960s and 1970s counterparts were rebelling against. Because of the lead characters' relatively tame and boring lifestyles, the film is not really rebellious or transgressive. In order to deal with the symptoms of their mid-life crisis, the 'wild hogs' decide to undertake a cross-country trip, hoping to discover a sense of freedom that they otherwise do not have. However, since the characters are engaged in a 'quest' form of a journey, the film seems more like a road movie than a biker film. As a result, Wild Hogs can be read as an indication of the road movie's dominance over the biker film.

Nonetheless, an outlaw biker gang does appear in Wild Hogs, functioning as the antagonistic force of the film. However, these actual biker characters are stereotypes, as they strongly resemble conservative, Right-wing bikers and real biker gangs because they are muscular, tattooed and threatening. However, since Wild Hogs is a comedy with slapstick elements, the biker gang does not carry the same menace as those featured in the 1960s and 1970s biker films, and thus they remain stereotypes. The end credit sequences in particular compromises their renegade biker lifestyle. In this scene, the film features a mock version of an Extreme Makeover: Home Edition television segment. The biker gang receives a new, superior clubhouse after their old one was accidentally burned down by Woody, one of the four Wild Hogs. After the bikers' new clubhouse is unveiled by the show's host, the gang members start crying and become uncontrollably emotional. This appears to go completely against an important convention of the 1960s and 1970s biker film and character type, which is that bikers do not show any weakness, least of all unmanly tears. Therefore, because these bikers are reduced to weeping 'softies', this could be seen as signalling the death of the hardened, hedonistic, and hypermasculine biker gang lifestyle that was foregrounded in the biker films of the 1960s and 1970s. This sequence also addresses the notion that, in the present day, bikers 
have become so mediated that they only appear in popular culture as stereotypes and caricatures.

Although Wild Hogs can be seen as the allegorical death of the biker film, the outlaw biker gang lifestyle appears to have recently risen from the ashes in the television programme Sons of Anarchy. The series examines the problems of a gang involved in organised crime and drug distribution. This subject matter parallels the activities of real contemporary motorcycle gangs, and recalls the link between real gangs and those depicted in the biker gang films. However, there are differences between this show and the earlier biker films. For example, Sons of Anarchy does not have the same frequency of violence as in the biker films. The programme also constructs the bikers as sympathetic figures, especially by dealing with the hardships in their personal lives. The first season, for example, focuses on the protagonist Jax's emotional struggles in dealing with the premature birth of his unhealthy baby son. As we have seen, biker characters in earlier biker films have little backstory, nor do they have to contend with major personal problems or domestic issues. This leaves them (and the films) to concentrate on their transgressive, mobile, and violent lifestyle.

We might also read this re-emergence of 'authentic' biker gangs in Sons of Anarchy in allegorical terms. This revival is somewhat of a compromise. As the sons of anarchy, the bikers in the televisions series are not the original anarchists (that is, the renegade bikers), but their descendants. As a result, they are not as fierce as their predecessors, as the comparative lack of violence and emphasis on personal issues indicated. It could also be argued that the biker gang in the present day has become somewhat institutionalized through their involvement in organized crime. In this respect, it is interesting that the program has been made within the industrial framework of network TV, while the 1960s and 1970s biker films were all independently produced. With this in mind, it seems unlikely that there will be a resurgence of films such as The Wild Angels, Hell's Angels on Wheels and The Born Losers, or the characters who make them so fascinating. It would seem that the character of the outlaw biker and his gang has been recycled, mutated and exhausted. 


\section{Future Research}

However, despite the decline and eventual disappearance of the film, there are still some opportunities for further research. This thesis has argued that the 1960s and 1970s biker film is significant for a number of reasons. This group of films forms clearly belongs to the diverse range of exploitation films that were produced in the United States in the post-War period. Moreover, they also form part of the social, cultural and industrial fabric of New Hollywood cinema. In this respect, this study is a small contribution to the much larger and ongoing research on New Hollywood cinema. Eventually it may be possible to understand what constitutes 'post-classical' filmmaking in New Hollywood cinema through the integration of histories and analyses of Left and Right cycle films, production histories, narrative and stylistic elements, and genre revisionism. As part of this, there is further work to be done on the production, distribution, exhibition and reception of the biker films, particularly empirical research.

This thesis has also demonstrated that the biker film should be seen as part of a continuum of filmmaking that follows the revisionist Western and leads to the contemporary Hollywood action film. The biker film's emphasis on features that excite, shock or otherwise 'attract' its audience members foreshadows the ways in which the action film's stimulation of its audience frequently takes precedence over its narrative elements. In this respect, this project has also contributed to the ways to discussions about narrative and spectacle, which are also a part of the discourse surrounding post-classical Hollywood cinema.

One area that brings both New Hollywood cinema and the action film together is the road movie. Although there has been a considerable amount of research done on the genre in the 1960s and 1970s, it is surprising that there is a significant group of road movies which have received comparatively little academic analysis. These are the comic road films of the 1970s and early 1980s, examples of which include Smokey and the Bandit (1977), The Gumball Rally 
(1976), Convoy (1978), and The Cannonball Run. These films, of course, do not involve 'quest' journeys, nor are they about violent outlaw couples of the kind found in Badlands or Bonnie and Clyde. Instead, these films focus on comedy and slapstick narratives. The cross-country automobile race is foregrounded in the narratives of The Gumball Rally and The Cannonball Run, whereas the chase scenario - usually involving comic characters being chased by the law across America - features in Smokey and the Bandit and Convoy. In this respect, the chase film can be connected to the road movie featuring the outlaw couple, who are similarly chased by authority.

There are, of course, obvious differences between the biker film and the comic road movies in terms of production values, tone and reception. However, both contain a large number of action sequences, particularly vehicle stunts and crashes. The protagonists of the comedy road movie are generally antiauthoritarian: a common feature of these films is the way in which the central characters evade apprehension and humiliate the police in the process. The two genres might also be connected through an analysis of genre. The comic road movie frequently employs gender stereotypes and contains exploitative sexual elements. Further analysis of the comic road movie would contribute to both the discourse on New Hollywood cinema and the action film. A comparison with the biker film would also enhance our understanding of the significance of less reputable genres such as action and comedy in American cinema in the postclassical period after 1965. Although some of our companions on the journey may be boisterous and perhaps need a shower, it is only by taking the roads less travelled that we will reach a fuller understanding of the Hollywood Renaissance and its relationship to contemporary Hollywood cinema. 
Fig. 1

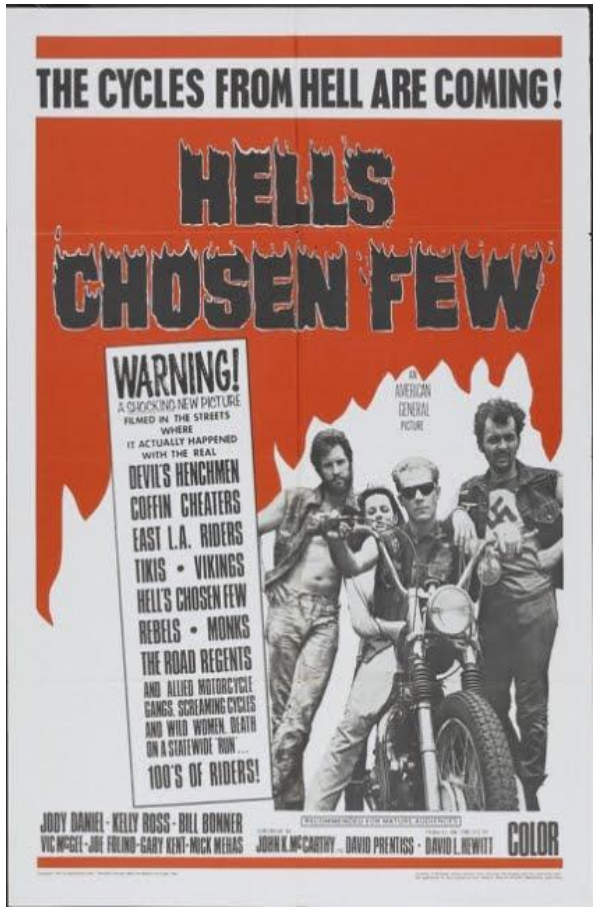

Fig. 3

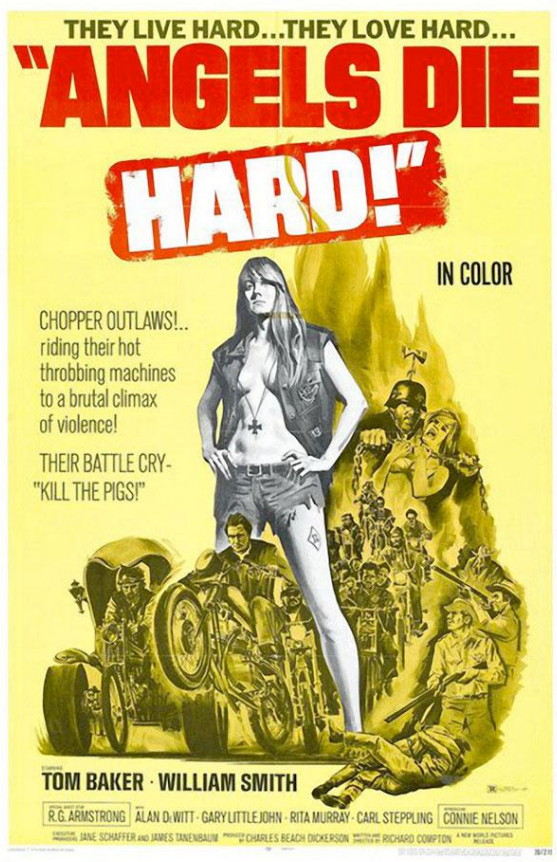

Fig. 2

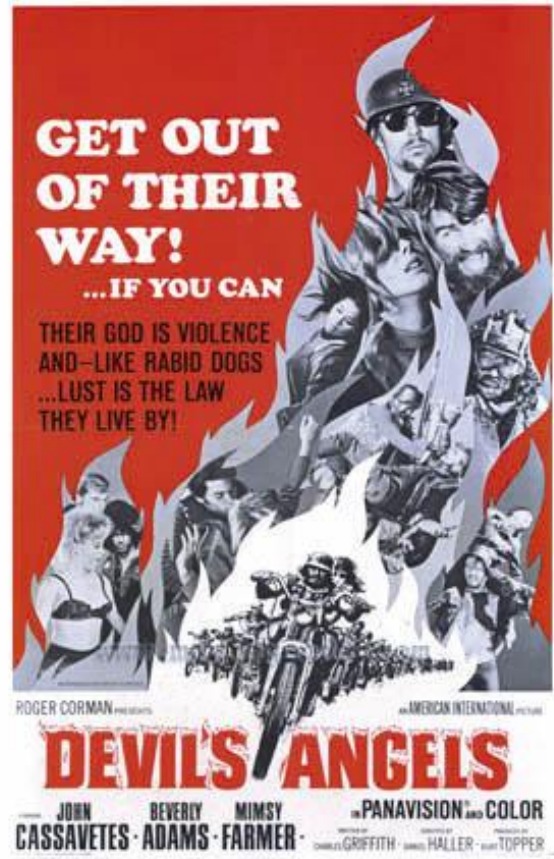

Fig. 4

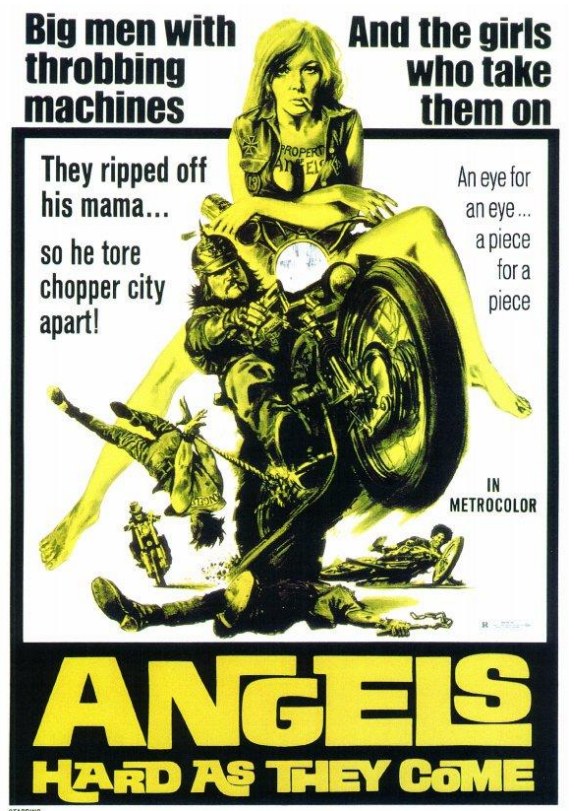

SCOTT GLENH·CHARLES DIERKOP.GILDA TEXTER · JAMES IGLEHART

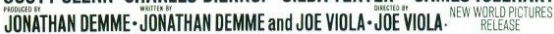


Fig. 5

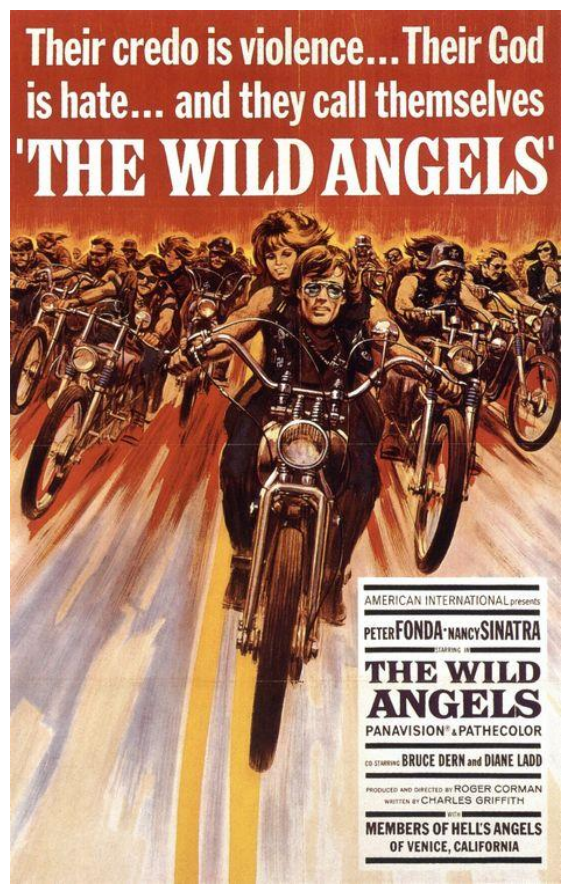

Fig. 7

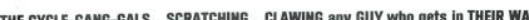

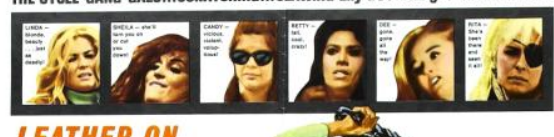

LEATHER ON

- THE OUTSIDE

...ALL WOMAN ON THE

INSIDE!
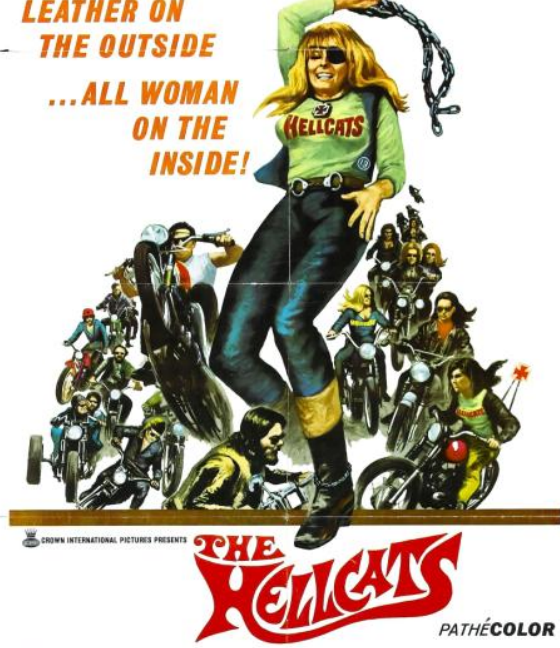

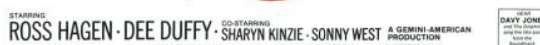

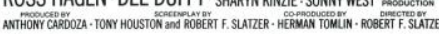

Fig. 6

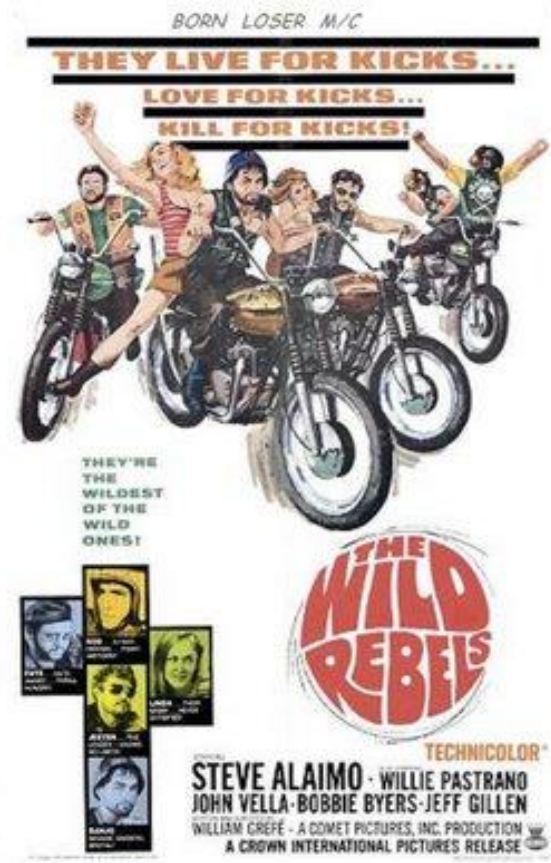

Fig. 8.

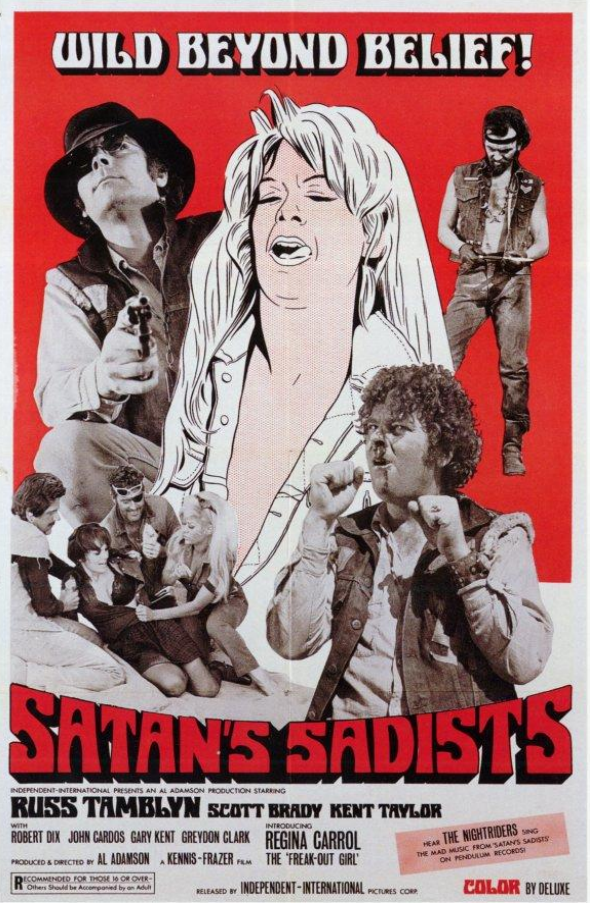




\section{Bibliography}

Amidon, K.S. and Krier, D. "On Rereading Klaus Theweleit's Male Fantasies." Men and Masculinities. Vol. 11, No. 4. (June 2009.) 488-496.

Atkinson, M. “Crossing the Frontiers.” Sight and Sound 1. 1994. 14-18.

Banks, C. Criminal Justice Ethics: Theory and Practice. Thousand Oaks, CA, London and New Delhi: Sage Publications, 2004.

Baxter, J. Hollywood in the Sixties. London and New York: Tantivy Press, A.S. Barnes, 1972.

Beard, W. Persistence of Double Vision: Essays on Clint Eastwood. Edmonton: University of Alberta Press, 2000.

Belton, J. American Cinema/American Culture. New York: McGraw-Hill, 2009.

Benshoff, H.M. and Griffin, S. America on Film: Representing Race, Class, Gender, and Sexuality at the Movies. Malden, MA, Oxford, and Carlton, Victoria: Blackwell Publishing, 2004.

Berliner, T. "The Genre Film as Booby Trap: 1970s Genre Bending and The French Connection." Cinema Journal. Vol. 40, No. 3. (Spring 2001.) 25-46.

Biltereyst, D. “American Juvenile Delinquency Movies and the European Censors: The Cross-Cultural Reception and Censorship of The Wild One, Blackboard Jungle, and Rebel Without a Cause." Shary, T. and Seibel, A. (eds.) Youth Culture in Global Cinema. Austin: University of Texas Press, 2007. 9-26.

Bingham, D. Acting Male: Masculinities in the Films of James Stewart, Jack Nicholson, and Clint Eastwood. New Brunswick, N.J.: Rutgers University Press, 1994.

Bodroghkozy, A. "Reel Revolutionaries: An Examination of Hollywood's Cycle of 1960s Youth Rebellion Films." Cinema Journal Vol. 41, No. 3. (Spring 2002.) 38-57.

Bordwell, D. Narration in the Fiction Film. Madison: University of Wisconsin Press, 1985.

Bordwell, D., Staiger, J. and Thompson, K. The Classical Hollywood Cinema: Film Style \& Mode of Production to 1960. New York: Columbia University Press, 1985.

Bordwell, D. and Thompson, K. Film Art: An Introduction (Seventh edition). New York: McGraw-Hill, 2003. 
Boyle, K. Media and Violence. London, Thousand Oaks, California and New Delhi: SAGE Publications, 2005.

Brake, M. Comparative Youth Culture: The Sociology of Youth Cultures and Youth Subcultures in America, Britain and Canada. London and New York: Routledge \& Kegan Paul, 1985.

Brinkley, D. "Introduction." Thompson, H.S. Hell's Angels: A Strange and Terrible Saga. New York: The Modern Library, 1999 [1967.] ix-xiii.

Buckland, W. Directed by Steven Spielberg: Poetics of the Contemporary Hollywood Blockbuster. New York and London: Continuum, 2006.

Bukatman, S. "Zooming Out: The End of Offscreen Space." Lewis, J. (ed.) The New American Cinema. Durham, NC: Duke University Press, 1998. 248-272.

Carroll, N. and Choi, J. "Introduction to Part VII." Carroll, N. and Choi, J. (eds.) Philosophy of Film and Motion Pictures: An Anthology. Malden, MA, Oxford and Carlton, Victoria: Blackwell Publishing, 2006. 323-334.

Cawelti, J.G. The Six-Gun Mystique Sequel. Bowling Green: Bowling Green State University Popular Press, 1999.

Cohan, S. and Hark, I.R. "Introduction." Cohan, S. and Hark, I.R. (eds.) The Road Movie Book. London and New York: Routledge, 1997. 1-14.

Cohen, S. Folk Devils and Moral Panics: The Creation of the Mods and Rockers. London: MacGibbon and Kee, 1972.

Cook, D.A. Lost Illusions: American Cinema in the Shadow of Watergate and Vietnam, 1970-1979. Berkeley: University of California Press, 2002.

Corman, R. with Jerome, J. How I Made a Hundred Movies in Hollywood and Never Lost a Dime. New York: Random House, 1990.

Corrigan, T. A Cinema Without Walls: Movies and Culture After Vietnam. New Brunswick, N.J.: Rutgers University Press, 1991.

Coulthart, R. and McNab, D. Above the Law: How Outlaw Motorcycle Gangs Established the World's Biggest Criminal Empire. Crows Nest, NSW: Allen \& Unwin, 2010.

Creed, B. "From Here to Modernity - Feminism and Postmodernism." Screen. Vol. 28, No. 2. (1987.) 46-67.

Creed, B. "The Neomyth in Film: The Woman Warrior from Joan of Arc to Ellen Ripley." Andris, S and Frederick, U. (eds.) Women Willing to Fight: The Fighting Woman in Film. Newcastle: Cambridge Scholars Publishing, 2007. 1537. 
Creekmur, C.K. "On the Run and On the Road: Fame and the Outlaw Couple in American Cinema." Cohan, S. and Hark, I.R. (eds.) The Road Movie Book. London and New York: Routledge, 1997. 90-109.

Doherty, T. Teenagers \& Teenpics: The Juvenilization of American Movies in the 1950s. Boston: Unwin Hyman, 1988.

Elsaesser, T. "American Auteur Cinema: The Last - or First - Great Picture Show." Elsaesser, T., Horwath, A. and King, N. (eds.) The Last Great American Picture Show: New Hollywood Cinema in the 1970s. Amsterdam: Amsterdam University Press, 2004. 37-69.

Elsaesser, T. "The Pathos of Failure: American Films in the 1970s: Notes on the Unmotivated Hero." Elsaesser, T., Horwath, A. and King, N. (eds.) The Last Great American Picture Show: New Hollywood Cinema in the 1970s. Amsterdam: Amsterdam University Press, 2004. 279-292.

Farrell, W.J. "Social Construction of Gangs." Kontos, L. and Brotherton, D. (eds.) Encyclopedia of Gangs. Westport, CT: Greenwood Publishing Group, 2008. 218-222.

Feldman, C.J. "We Are the Mods": A Transitional History of a Youth Subculture. New York: Peter Lang Publishing, 2009.

Flanagan, M. “'Get Ready for Rush Hour': The Chronotope in Action.” Tasker, Y. (ed.) Action and Adventure Cinema. London and New York: Routledge, 2004. 103-118.

Frayling, C. Spaghetti Westerns: Cowboys and Europeans from Karl May to Sergio Leone. London and New York: I.B. Tauris, 2006.

Friedman, L.D. "Movies and the 1970s." Friedman, L.D. (ed.) American Cinema of the 1970s: Themes and Variations. New Brunswick, N.J.: Rutgers University Press, 2007. 1-23.

Fulwood, N. One Hundred Violent Films That Changed Cinema. London: Batsford, 2003.

Gair, C. The American Counterculture. Edinburgh: Edinburgh University Press, 2007.

Gallafent, E. Clint Eastwood: Actor and Director. London: Studio Vista, 1994.

Gomery, D. Movie History: A Survey. Belmont, CA: Wadsworth Publishing Company, 1991.

Gunning, T. "An Aesthetic of Astonishment: Early Film and the (In)Credulous Spectator." Williams, L. (ed.) Viewing Positions: Ways of Seeing Film. New Brunswick, N.J.: Rutgers University Press, 1995. 114-133. 
Gunning, T. "The Cinema of Attraction: Early Film: Its Spectator and the Avant-Garde." Stam, R. and Miller, T. (eds.) Film and Theory: An Anthology. Malden, Mass. and Oxford, UK: Blackwell Publishing, 2000. 229-235.

Günsberg, M. Italian Cinema: Gender and Genre. Houndmills, Basingstoke, Hampshire and New York: Palgrave Macmillan, 2005.

Hark, I.R. "Fear of Flying: Yuppie Critique and the Buddy-Road Move in the 1980s." Cohan, S. and Hark, I.R. (eds.) The Road Movie Book. London and New York: Routledge, 1997. 204-229.

Hayward, S. Cinema Studies: The Key Concepts. London and New York: Routledge, 2000.

Author unknown. "The Hells Angels - Dynamics of Organized Crime." http://www.freeonlineresearchpapers.com/hells-angels-organized-crime

Hendley, N. American Gangsters, Then and Now. Santa Barbara, Denver and London: ABC-CLIO, 2010.

Hill, L. Easy Rider. London: BFI Publishing, 1996.

Hoberman, J. The Dream Life: Movies, Media, and the Mythology of the Sixties. New York and London: The New Press, 2003.

Horwath, A. "The Impure Cinema: New Hollywood 1967-1976." Elsaesser, T., Horwath, A. and King, N. (eds.) The Last Great American Picture Show: New Hollywood Cinema in the 1970s. Amsterdam: Amsterdam University Press, 2004. 9-17.

Horwath, A. "A Walking Contradiction (Partly Truth and Partly Fiction)." Elsaesser, T., Horwath, A. and King, N. (eds.) The Last Great American Picture Show: New Hollywood Cinema in the 1970s. Amsterdam: Amsterdam University Press, 2004. 83-105.

Ireland, B. "American Highways: Recurring Images and Themes of the Road Genre." The Journal of American Culture. Vol. 26, No. 4. (December 2003.) 474-484.

Issitt, M. Hippies: A Guide to an American Subculture. Santa Barbara: ABCCLIO, 2010.

Jeffords, S. “Can Masculinity Be Terminated?" Cohan, S. and Rae Hark, I. (eds.) Screening the Male: Exploring Masculinities in Hollywood Cinema. London and New York: Routledge, 1993. 245-262.

Kaminsky, S. Don Siegel: Director. New York: Curtis, 1974. 
Kanfer, S. "The Shock of Freedom in Films." McClure, A.F. (ed.) The Movies: An American Idiom. Rutherford: Fairleigh Dickinson University Press, 1971 [1967]. 322-333.

Kass, J.M. Don Siegel. London: Tantivy, 1975.

Kerouac, J. On the Road. New York: Penguin, 1976 [1957].

King, G. New Hollywood Cinema: An Introduction. New York: Columbia University Press, 2002.

King, G. "Spectacle, Narrative, and the Spectacular Hollywood Narrative." Stringer, J. (ed.) Movie Blockbusters. New York: Routledge, 2003. 114-127.

King, G. Spectacular Narratives: Hollywood in the Age of the Blockbuster. London and New York: I.B. Tauris, 2000.

King, N. “"The Last Good Time We Ever Had': Remembering the New Hollywood Cinema." Elsaesser, T., Horwath, A. and King, N. (eds.) The Last Great American Picture Show: New Hollywood Cinema in the 1970s. Amsterdam: Amsterdam University Press, 2004. 19-36.

Kitses, J. Horizons West: Directing the Western from John Ford to Clint Eastwood. London: BFI Publishing, 2004.

Klinger, B. "The Road to Dystopia: Landscaping the Nation in Easy Rider." Cohan, S. and Hark, I.R. (eds.) The Road Movie Book. London and New York: Routledge, 1997. 179-203.

Krämer, P. The New Hollywood: From Bonnie and Clyde to Star Wars. London and New York: Wallflower, 2005.

Kramer, P. "Post-classical Hollywood." Hill, J. and Church Gibson, P. (eds.) American Cinema and Hollywood: Critical Approaches. Oxford: Oxford University Press, 2000. 63-83.

Laderman, D. Driving Visions: Exploring the Road Movie. Austin: University of Texas Press, 2002.

Langford, R. "The Post-Colonial Cowboy: Masculinity, the Western Genre and Francophone African Film.” Fouz-Hernández, S. (ed.) Mysterious Skin: Male Bodies in Contemporary Cinema. London and New York: I.B. Tauris, 2009. 7792.

Lev, P. American Films of the 70s: Conflicting Visions. Austin: University of Texas Press, 2000.

Lévi-Strauss, C. Structural Anthropology. New York and London: Basic Books, 1963. 
Librett, M. "Outlaw Bikers." Kontos, L. and Brotherton, D. (eds.) Encyclopedia of Gangs. Westport, CT: Greenwood Publishing Group, 2008. 181-187.

Lott, M.R. The American Martial Arts Film. Jefferson, N.C.: McFarland \& Company, 2004.

Mallory, S.L. Understanding Organized Crime. Sudbury, MA, Mississauga, Ontario and London: Jones and Bartlett Publishers, 2007.

Maltby, R. "The Classical Hollywood Cinema." Hollows, J., Hutchings, P. and Jancovich, M. (eds.) The Film Studies Reader. London: Arnold, 2000. 166-173.

Martin, A. The Mad Max Movies. Strawberry Hills, NSW: Currency Press, 2003.

Mask, M. "1971: Movies and the Exploitation of Excess.” Friedman, L.D. (ed). American Cinema of the 1970s: Themes and Variations. New Brunswick, N.J.: Rutgers University Press, 2007. 48-70.

McDonagh, M. "The Exploitation Generation. Or: How Marginal Movies Came in from the Cold." Elsaesser, T., Horwath, A. and King, N. (eds.) The Last Great American Picture Show: New Hollywood Cinema in the 1970s. Amsterdam: Amsterdam University Press, 2004. 107-130.

Miller, T. The Hippies and American Values. Knoxville: The University of Tennessee Press, 1991.

Mills, K. The Road Story and the Rebel: Moving Through Film, Fiction and Television. Carbondale: Southern Illinois University Press, 2006.

Mitchell, L.C. "Violence in the Film Western." Slocum, J.D. (ed.) Violence and American Cinema. New York and London: Routledge, 2001. 176-191.

Modleski, T. “A Rose Is a Rose? Real Women and a Lost War.” Lewis, J. (ed.) The New American Cinema. Durham, NC: Duke University Press, 1998. 125145.

Monaco, P. The History of American Cinema: The Sixties 1960-1969. New York and Detroit: Charles Scribner's Sons, 2001.

Mordden, E. Medium Cool: The Movies of the 1960s. New York: Knopf, 1990.

Morton, J. "Rebels of the Road: The Biker Film." Sargeant, J. and Watson, S. (eds.) Lost Highways. Creation Books, 1999. 55-66.

Neale, S. "Action-Adventure as Hollywood Genre." Tasker, Y. (ed.) Action and Adventure Cinema. London and New York: Routledge, 2004. 71-83.

Neale, S. Genre and Hollywood. London and New York: Routledge, 2000. 
Neale, S. "Masculinity as Spectacle: Reflections on Men and Mainstream Cinema." Cohan, S. and Rae Hark, I. (eds.) Screening the Male: Exploring Masculinities in Hollywood Cinema. London and New York: Routledge, 1993. 9-20.

Neroni, H. The Violent Woman: Femininity, Narrative, and Violence in Contemporary American Cinema. Albany: State University of New York Press, 2005.

O’Donnell, V. "Science Fiction Films and Cold War Anxiety.” Lev, P. (ed.) History of American Cinema: The Fifties: Transforming the Screen. New York: Charles Scribner's Sons: Thomson, Gale, 2003. 169-196.

Osgerby, B. 'Sleazy Riders; Exploitation, 'Otherness,' and Transgression in the 1960s Biker Movie." Journal of Popular Film and Television. Vol. 31, No. 3. (Fall 2003.) 98-108.

Perlman, A. "The Brief Ride of the Biker Movie." International Journal of Motorcycle Studies. March 2007. [online journal]. http://ijms.nova.edu/March2007/IJMS_Artcl.Perlman.html

Perry, C. The Haight-Ashbury: A History. New York: Wenner Books, 2005.

Pfeil, F. "From Pillar to Postmodern: Race, Class, and Gender in the Male Rampage Film." Lewis, J. (ed.) The New American Cinema. Durham, NC: Duke University Press, 1998. 146-186.

Plantinga, C. Moving Viewers: American Film and the Spectator's Experience. Berkeley, Los Angeles and London: University of California Press, 2009.

Ray, R.B. A Certain Tendency of the Hollywood Cinema, 1930-1980. Princeton, N.J.: Princeton University Press, 1985.

Roberts, S. "Western Meets Eastwood: Genre and Gender on the Road." Cohan, S. and Hark, I.R. (eds.) The Road Movie Book. London and New York: Routledge, 1997. 45-69.

Robnik, D. “Allegories of Post-Fordism in 1970s New Hollywood: Countercultural Combat Films and Conspiracy Thrillers as Genre Recycling." Elsaesser, T., Horwath, A. and King, N. (eds.) The Last Great American Picture Show: New Hollywood Cinema in the 1970s. Amsterdam: Amsterdam University Press, 2004. 333-358.

Rosenbaum, J. "New Hollywood and the Sixties Melting Pot." Elsaesser, T., Horwath, A. and King, N. (eds.) The Last Great American Picture Show: New Hollywood Cinema in the 1970s. Amsterdam: Amsterdam University Press, 2004. 131-152. 
Rubin, G. "The Traffic in Women: Notes on the 'Political Economy' of Sex." Nicholson, L. (ed.) The Second Wave: A Reader in Feminist Theory. New York and London: Routledge, 1997. 27-62.

Rubin, M. "Make Love Make War: Cultural Confusion and the Biker Film Cycle." Film History. Vol. 6, No. 3. (Autumn 1994.) 355-381.

Sargeant, J. and Watson, S. "Introduction." Sargeant, J. and Watson, S. (eds.) Lost Highways: An Illustrated History of Road Movies. London: Creation, 1999. 5-20.

Saunders, J. The Western Genre: From Lordsburg to Big Whiskey. London: Wallflower, 2001.

Schatz, T. Old Hollywood/New Hollywood: Ritual, Art, and Industry. Ann Arbour, Mich.: UMI Research Press, 1983.

Scholte, B. "Epistemic Paradigms: Some Problems in Cross-Cultural Research on Social Anthropology History and Theory." Hayes, E.N. and Hayes, T. (eds.) Claude Lévi-Strauss: The Anthropologist as Hero. Cambridge, Massachusetts and London: The M.I.T. Press, 1970. 108-122.

Schwartz, R.A. The 1950s. New York: Facts on File, 2003.

Smith, G.M. Film Structure and the Emotion System. Cambridge: Cambridge University Press, 2003.

Smith, J. "From Misogynies: Crawling from the Wreckage." Gioseffi, D. (ed.) Women on War: An International Anthology of Writings from Antiquity to the Present. New York: Feminist Press, 2003. 70-79.

Smith, P. Clint Eastwood: A Cultural Production. Minneapolis and London: University of Minnesota Press, 1993.

Stam, R., Burgoyne, R. and Flitterman-Lewis, S. New Vocabularies in Film Semiotics: Structuralism, Post-Structuralism and Beyond. London and New York: Routledge, 1992.

Stringer, J. "Exposing Intimacy in Russ Meyer's Motorpsycho! and Faster Pussycat! Kill! Kill!." Cohan, S. and Hark, I.R. (eds.) The Road Movie Book. London and New York: Routledge, 1997. 165-178.

Syder, A. "Ripped from Today's Headlines: The Outlaw Biker Movie Cycle". December 2002. [online journal].

http://www.scope.nottingham.ac.uk/article.php?issue $=$ dec $2002 \& \mathrm{id}=271 \&$ sectio $\underline{\mathrm{n}=\text { article }}$

Tasker, Y. "Dumb Movies For Dumb People: Masculinity, the Body, and the Voice in Contemporary Action Cinema." Cohan, S. and Rae Hark, I. (eds.) 
Screening the Male: Exploring Masculinities in Hollywood Cinema. London and New York: Routledge, 1993. 230-244.

Tasker, Y. "Introduction: Action and Adventure Cinema." Tasker, Y. (ed.) Action and Adventure Cinema. London and New York: Routledge, 2004. 1-13.

Tasker, Y. Spectacular Bodies: Gender, Genre and the Action Cinema. London and New York: Routledge, 1993.

Tendler, S. and May, D. The Brotherhood of Eternal Love - From Flower Power to Hippie Mafia: The Story of the LSD Counterculture. London: Cyan Books, 2007.

Theweleit, K. Male Fantasies I: Women, Floods, Bodies, History. Cambridge: Polity Press, 1987.

Thompson, H. "Hell's Angels: Hoodlum Circus and Statutory Rape of Bass Lake.” Douglas, J.D. (ed.) Observations of Deviance. New York: Random House, 1970. 131-145.

Thompson, H.S. Hell's Angels: A Strange and Terrible Saga. New York: The Modern Library, 1999 [1966].

Tzioumakis, Y. American Independent Cinema: An Introduction. Edinburgh: Edinburgh University Press, 2006.

Wolfe, T. The Electric Kool-Aid Acid Test. London: Black Swan, 1968.

Wooley, J. and Price, M.H. The Big Book of Biker Flicks: 40 of the Best Motorcycle Movies of All Time. Tulsa, OK: Hawk Publishing Group, 2005.

Young, J. "Moral Panics." Kontos, L. and Brotherton, D. (eds.) Encyclopedia of Gangs. Westport, CT: Greenwood Publishing Group, 2008. 174-176.

\section{Filmography}

Activist, The. (Art Napoleon, USA, 1969).

Alice's Restaurant. (Arthur Penn, USA, 1969).

Alien. (Ridley Scott, USA/UK, 1979).

Aliens. (James Cameron, USA/UK, 1986).

Angel Unchained. (Lee Madden, USA, 1970).

Angels Die Hard. (Richard Compton, USA, 1970).

Angels from Hell. (Bruce Kessler, USA, 1968). 
Angels Hard as They Come. (Joe Viola, USA, 1971).

Angels' Wild Women. (Al Adamson, USA, 1972).

Any Which Way You Can. (Buddy Van Horn, USA, 1980).

Arrival of a Train at the Station. (Auguste Lumière, Louis Lumière, France, 1896).

Badlands. (Terrence Malick, USA, 1973).

Beach Blanket Bingo. (William Asher, USA, 1965).

Beach Party. (William Asher, USA, 1963).

Bikini Beach. (William Asher, USA, 1964).

Billy Jack. (Tom Laughlin, USA, 1971).

Black Angels, The. (Laurence Merrick, USA, 1970).

Black Six, The. (Matt Cimber, USA, 1973).

Bonnie and Clyde. (Arthur Penn, USA, 1967).

Born Losers, The. (Tom Laughlin, USA, 1967).

Boxcar Bertha. (Martin Scorsese, USA, 1972).

Bring Me the Head of Alfredo Garcia. (Sam Peckinpah, USA/Mexico, 1974).

Bullitt. (Peter Yates, USA, 1968).

Bury Me an Angel. (Barbara Peeters, USA, 1972).

C.C. and Company. (Seymour Robbie, USA, 1970).

Cannonball Run, The. (Hal Needham, USA, 1981).

Chrome and Hot Leather. (Lee Frost, USA, 1971).

Convoy. (Sam Peckinpah, USA, 1978).

Coogan's Bluff. (Don Siegel, USA, 1968).

Cycle Psycho. (John Lawrence, USA, 1973).

Cycle Savages, The. (Bill Brame, USA, 1969). 
Death Wish. (Michael Winner, USA, 1974).

Devil Rider! (Brad F. Grinter, USA, 1970).

Devil's Angels. (Daniel Haller, USA, 1967).

Die Hard. (John McTiernan, USA, 1988).

Dirty Harry. (Don Siegel, USA, 1971).

Dirty Mary, Crazy Larry. (John Hough, USA, 1974).

Dr. Goldfoot and the Bikini Machine. (Norman Taurog, USA, 1965).

Duel. (Steven Spielberg, USA, 1971).

Easy Rider. (Dennis Hopper, USA, 1969).

Every Which Way But Loose. (James Fargo, USA, 1978).

Faster, Pussycat! Kill! Kill! (Russ Meyer, USA, 1965).

First Blood. (Ted Kotcheff, USA, 1982).

A Fistful of Dollars. (Sergio Leone, Italy/Spain/West Germany, 1964).

Five Easy Pieces. (Bob Rafelson, USA, 1970).

For a Few Dollars More. (Sergio Leone, Italy/Spain/West Germany, 1965).

French Connection, The. (William Friedkin, USA, 1971).

Gas! -Or-It Became Necessary to Destroy the World in Order to Save It. (Roger Corman, USA, 1970).

Getting Straight. (Richard Rush, USA, 1970).

Ghost in the Invisible Bikini, The. (Don Weis, USA, 1966).

Gimme Shelter. (Documentary, Albert Maysles, David Maysles, Charlotte Zwerin, USA, 1970).

Glory Stompers, The. (Anthony M. Lanza, USA, 1968).

Good, the Bad and the Ugly, The. (Sergio Leone, Italy/Spain/West Germany, 1966).

Graduate, The. (Mike Nichols, USA, 1967).

Greetings. (Brian De Palma, USA, 1968). 
Gumball Rally, The. (Charles Bail, USA, 1976).

Hard Ride, The. (Burt Topper, USA, 1971).

Hell Riders. (James Bryan, USA, 1984).

Hell's Angels '69. (Lee Madden, USA, 1969).

Hell's Angels on Wheels. (Richard Rush, USA, 1967).

Hell's Belles. (Maury Dexter, USA, 1969).

Hell's Bloody Devils. (Al Adamson, USA, 1970).

Hell's Chosen Few. (David L. Hewitt, USA, 1968).

Hellcats, The. (Robert F. Slatzer, USA, 1967).

High Plains Drifter. (Clint Eastwood, USA, 1973).

Hog Wild. (Les Rose, Canada, 1980).

How to Stuff a Wild Bikini. (William Asher, USA, 1965).

Independence Day. (Roland Emmerich, USA, 1996).

J.C. (William F. McGaha, USA, 1972).

Jesus Trip, The. (Russ Mayberry, USA, 1971).

Joe. (John G. Avildsen, USA, 1969).

Long Kiss Goodnight, The. (Renny Harlin, USA, 1996).

Mad Max. (George Miller, Australia, 1979).

Mad Max 2. (George Miller, Australia, 1981).

Medium Cool. (Haskell Wexler, USA, 1969).

Midnight Cowboy. (John Schlesinger, USA, 1969).

Mini-Skirt Mob, The. (Maury Dexter, USA, 1968).

Motorcycle Gang. (Edward L. Kahn, USA, 1957).

Motorpsycho. (Russ Meyer, USA, 1965).

Naked Angels. (Bruce D. Clark, USA, 1969). 
Nam's Angels. (Jack Starrett, USA, 1970).

Once Upon a Time in the West. (Sergio Leone, Italy/USA, 1968).

Outlaw Riders. (Tony Huston, USA, 1971).

Pajama Party. (Don Weis, USA, 1964).

Patton. (Franklin J. Schaffner, USA, 1970).

Peace Killers, The. (Douglas Schwartz, USA, 1971).

Pink Angels, The. (Larry G. Brown, USA, 1971).

Proud Rider, The. (Walter Baczynsky, Canada, 1971).

Psych-Out. (Richard Rush, USA, 1968).

Quadrophenia. (Franc Roddam, UK, 1979).

Rain People, The. (Francis Ford Coppola, USA, 1969).

Rambo: First Blood Part II. (George P. Cosmatos, USA, 1985).

Rebel Rousers. (Martin B. Cohen, USA, 1970).

R.P.M. (Stanley Kramer, USA, 1970).

Road of Death. (Rene Martinez Jr., USA, 1973).

Run Angel Run! (Jack Starrett, USA, 1969).

Satan's Sadists. (Al Adamson, USA, 1969).

Savage Seven, The. (Richard Rush, USA, 1968).

Savages from Hell. (Joseph P. Mawra, USA, 1968).

Scorpio Rising. (Kenneth Anger, USA, 1964).

She-Devils on Wheels. (Herschell Gordon Lewis, USA, 1968).

Sisters in Leather. (Zoltan G. Spencer, USA, 1969).

Smokey and the Bandit. (Hal Needham, USA, 1977).

Sons of Anarchy. (TV Series, created by Kurt Sutter, 2008-present).

Stone. (Sandy Harbutt, Australia, 1974). 
Stone Cold. (Craig R. Baxley, USA, 1991).

Stranger, The. (Fritz Kiersch, USA, 1995).

Strawberry Statement, The. (Stuart Hagmann, USA, 1970).

Survival Zone. (Percival Rubens, South Africa, 1983).

Terminator, The. (James Cameron, USA, 1984).

Terminator 2: Judgement Day. (James Cameron, USA, 1991).

Thelma \& Louise. (Ridley Scott, USA/France, 1991).

Thieves Like Us. (Robert Altman, USA, 1974).

Top Gun. (Tony Scott, USA, 1986).

Trip, The. (Roger Corman, USA, 1967).

Two Mules for Sister Sara. (Don Siegel, USA/Mexico, 1970).

Two-Lane Blacktop. (Monte Hellman, USA, 1971).

Vanishing Point. (Richard C. Sarafian, USA/UK, 1971).

Walking Tall. (Phil Karlson, USA, 1973).

Werewolves on Wheels. (Michel Levesque, USA, 1971).

Wild Angels, The. (Roger Corman, USA, 1966).

Wild Bunch, The. (Sam Peckinpah, USA, 1969).

Wild in the Streets. (Barry Shear, USA, 1968).

Wild Hogs. (Walt Becker, USA, 2007).

Wild One, The. (Laslo Benedek, USA, 1953).

Wild Rebels, The. (William Grefe, USA, 1967).

Wild Wheels. (Ken Osborne, USA, 1969).

Zabriskie Point. (Michelangelo Antonioni, USA, 1970). 